\title{
Has Private Participation in Water and Sewerage Improved Coverage? Empirical Evidence from Latin America."
}

\author{
George R.G. Clarke \\ Katrina Kosec \\ Scott Wallsten
}

\begin{abstract}
$\underline{\text { Abstract }}$
Introducing private sector participation (PSP) into the water and sewerage sectors in developing countries is difficult and controversial. Empirical studies on its effects are scant and generally inconclusive. Case studies tend to find improvements in the sector following privatization, but they suffer from selection bias and it is difficult to generalize from their results. To explore empirically the effects of PSP on coverage, we assemble a new dataset of connections to water and sewerage services at the city and province level based on household surveys in Argentina, Bolivia, and Brazil. The household surveys, conducted over a number of years, allow us to compile data before and after the introduction of PSP as well as from similar (control) regions that never privatized at all. Our analysis reveals that, in general, connection rates to piped water and sewerage improved following the introduction of PSP, consistent with the case study literature. We also find, however, that connection rates similarly improved in the control regions, suggesting that PSP, per se, may not have been responsible for those improvements. On the other hand, connection rates for the poorest households also tended to increase in the regions with PSP and in the control regions, suggesting that—in terms of connections at least_PSP did not harm the poor.
\end{abstract}

World Bank Policy Research Working Paper 3445, November 2004

The Policy Research Working Paper Series disseminates the findings of work in progress to encourage the exchange of ideas about development issues. An objective of the series is to get the findings out quickly, even if the presentations are less than fully polished. The papers carry the names of the authors and should be cited accordingly. The findings, interpretations, and conclusions expressed in this paper are entirely those of the authors. They do not necessarily represent the view of the World Bank, its Executive Directors, or the countries they represent. Policy Research Working Papers are available online at http://econ.worldbank.org.

\footnotetext{
${ }^{*}$ George Clarke and Katrina Kosec work for the Development Research Group at the World Bank. Scott Wallsten is a fellow at the AEI-Brookings Joint Center for Regulatory Studies and a resident scholar at the American Enterprise Institute. We would like to thank Gover Barja, Tim Irwin, Roger Noll, Ernesto Schargrodsky, and participants in the Stanford Conference on Sector Reform in Latin America for thoughtful comments.

Contact author: Scott Wallsten: AEI-Brookings Joint Center, 1150 17th Street, N.W., Washington, DC 20036. Fax: 202-862-7177. Phone: 202-862-5885. Email: swallsten@aei.org
} 


\section{Introduction}

From the end of the Second World War until the middle of the 1980s, network utilities (e.g., electricity, telecommunications, and water) were vertically and horizontally integrated monopolies in almost every country in the world. Although these monopolies were privately owned in a few countries, most notably in the United States, in most they were state-owned. By the late 1980s, a combination of technological change and a better understanding of the cost of monopoly (and state) provision led many observers to question whether this was an effective way of providing infrastructure services. ${ }^{1}$ This, in turn, led to sector reform, with governments privatizing state-owned enterprises, introducing competition in areas where it was possible, and forming new regulatory agencies. For the most part, reform appears to have improved performance. In particular, in the sector where most cross-country empirical work has focused, the telecommunications sector, there is strong evidence that competition and privatization have increased service availability, improved productivity, and reduced retail prices. ${ }^{2}$ Furthermore, evidence from individual country case studies in this sector appears consistent with the crosscountry results. ${ }^{3}$

Although there has been some liberalization in nearly all sectors, the extent of privatization, competition and de-regulation has varied greatly. In sectors where technological change has made competition feasible, such as telecommunications, most countries have liberalized entry and introduced private sector participation. In other sectors, however, reform has been more limited. In particular, privatization and competition remain relatively uncommon in water and sewerage, reflecting a lack of consensus about how to best organize the sector. This is reflected in the variation in the extent to which industrialized countries have involved private enterprises in water supply and sewerage (OECD 2000). For example, even in the United States, with its long history of private ownership in most infrastructure sectors, municipalities own and operate most water supply and sewerage systems. ${ }^{4}$

Two important differences between water and sewerage and other infrastructure sectors help explain the lack of consensus about how to organize the sector. First, the potential for competition is much more limited in water and sewerage than it is in electricity and telecommunications. Second, privatization has proven to be more difficult and more controversial in water and sewerage than in other sectors. As a result, reform has proceeded more slowly and, when reforms have occurred, private sector participation has usually been more limited.

1 See, for example, Winston (1993)

${ }^{2}$ Almost without exception, cross-county empirical research in both developed and developing countries has found that competition increases the number of telephone connections, improves productivity, and results in lower prices. The evidence on privatization is generally positive, although slightly less conclusive. Recent studies include Li and Xu (2002), Petrazzini (1996), Ros (1999), and Wallsten (2001).

${ }^{3}$ See, for example, Azam et al. (2002), Clarke et al. (2003), Galal and Nauriyal (1995), Haggarty et al. (2003), Laffont and N'Guessan (2002) and Shirley et al. (2002).

${ }^{4}$ In contrast, France, generally considered to be relatively interventionist, has a long history of private provision of water. 
Although, in principle, competition is possible in some areas of water supply and sewerage - for example competition would be possible for supply of bulk water in a multireservoir system or for sewage treatment (Noll 2002) - in practice, competition has been very limited. This reflects the expense and impracticality of transporting water or sewage over long distances, reducing the potential for competition for the supply of bulk water or sewage treatment, and that a large portion of the cost of supplying water and collecting sewage is tied up in the distribution network, an area where the potential for direct product market competition is limited. ${ }^{5}$ Although competition for the market is possible in theory, it has proven difficult to successfully implement this form of competition in most developing countries.

It has also proven difficult to introduce private sector participation in the water and sewerage sector. One reason for this is that privatization is more difficult when the private operator will be a monopoly than it is when it would operate in a competitive market. Even in the presence of competition, however, additional factors make private sector participation controversial. One is that water is both essential for life and is a natural resource that literally falls from the sky. Because of this, governments may encounter political and legal obstacles to selling sector assets to a private operator. ${ }^{6}$

A second reason why privatization is more difficult is that externalities are more pronounced in water and sewerage than in electricity or telecommunications. The most frequently cited externality is health. Although water users bear much of the cost of consuming impure water (i.e., in terms of lost earnings and the pain and inconvenience of disease), the cost is not fully internalized, especially for communicable diseases. Further, leaky pipes, which leave standing pools of water that can become breeding grounds for disease-carrying insects, and untreated sewage both result in large negative health externalities. Extracting water from its source causes additional externalities. When water is taken from an aquifer faster than it is replenished, the quality of the remaining water decreases - for example, the remaining water becomes increasingly difficult to extract and can become salinated, and large sinkholes can develop. For these reasons, externalities are more important in water and sewerage than they are in other network industries, increasing the potential scope of regulation beyond simple price.

A final reason why privatization is more difficult is that a large portion of sector assets are fixed in place, have no alternative uses and are extremely long-lived (e.g., the pipes). This makes them especially prone to expropriation by the government. Even if the government does not explicitly expropriate assets, it can implicitly do so by setting tariffs below long-term marginal cost. That is, because fixed costs make up such a large portion of total costs and because sector assets can keep operating for a long period without much in the way of maintenance, the government has a strong incentive to set tariffs so that they cover operating costs but do not provide resources for expansion or even adequate maintenance. Furthermore, the very long-term nature of fixed investment means that self-financing utilities will earn quasi-

\footnotetext{
${ }^{5}$ Approximately two-thirds of the cost of water supply is related to the cost of the supply network for water. In contrast, only 40 percent of the cost of supplying electricity is related to network components (London Economics 1998).

${ }^{6}$ See Noll (2002). As an example of this, Zérah et al. (2001) note that the Argentine government chose a concession contract in Buenos Aires over full privatization because selling sector assets would have posed legal problems.
} 
rents. This creates incentives for all sides to use them for purposes other than investment (e.g., consumer pressure to reduce tariffs, government pressure to use the funds for other needs, investor pressure not to reinvest depending on the likelihood of recouping the investment).

In addition to discouraging private sector participation altogether, these problems have resulted in countries adopting a wide range of different approaches towards private sector participation. Rather than simply selling water and sewerage utilities to private investors, many countries have adopted intermediate forms of private sector participation, including various types of franchising, lease contracts and concessions, and build-operate-transfer (BOT) contracts (e.g., Lee and Jouravlev 1997).

Despite these obstacles, sector reform is vital. Nearly 20 percent of the world's population does not have access to improved water and more than one-third does not have access to improved sanitation (Kessides 2003). The World Commission on Water estimated that mitigating water and sanitation problems would require US\$600-800 billion between 2000 and 2010 (as cited in Bourbigot and Picaud 2001). Beginning in the 1980s many countries - rich and poor - began experimenting with privatization of water systems as a means of boosting investment and increasing coverage, efficiency, and water quality. Indeed, in the 1990s developing countries initiated more than 100 water or sewerage projects involving private sector participation (Tynan 2000).

There is little existing rigorous evidence on the effects of introducing PSP into water and sewerage. In this paper we use household-level data to explore the effect on water and sewerage coverage over time (before and after privatization) and across cities, including compared to control cities that never privatized. While connections appear to have generally increased following privatization, the increases appear to be about the same as in cities that retained public ownership of their water systems. In other words, the analysis provides little evidence that privatization itself generated improvements in access. However, contrary to fears, we also find no evidence that poor people served by privatized firms received worse coverage than the poor served by public water utilities.

\section{EXISTING EMPIRICAL EVIDENCE}

Two broad groups of studies evaluate the effects of private sector participation on sector performance: multi-utility statistical analyses and single-utility case studies. ${ }^{7}$ Despite the importance of sector reform, few studies present rigorous statistical results. Further, the statistical and econometric studies that do exist for developing countries provide neither consistent evidence of strong improvements in sector performance following the introduction of private sector participation nor robust evidence regarding the relative success of different forms of private sector participation. The inconclusive empirical findings in developing countries are consistent with studies of industrialized countries, which also fail to reach a consensus on the relative performance of private and public providers (Anwandter and Ozuna 2002).

\footnotetext{
${ }^{7}$ In addition, some "case studies" compare results from multiple utilities, without performing formal statistical analysis. Further, in some other cases, separate case-studies are conducted using similar methodologies in order to make the results easier to compare. See, for example, the case studies in Shirley (2002)
} 
The weak evidence from cross-country analyses partially reflects the poor quality of data that are available: most studies have relied upon data from few countries for short periods of time. In contrast to cross-country studies in the telecommunications sector, which often rely upon hundreds or even thousands of observations from many countries over long periods of time, the main cross-country studies of private sector participation in the water sector use samples with fewer than 50 observations. ${ }^{8}$ Consequently, it might not be surprising that there is typically not enough variation either across countries or over time to find strong, statistically significant results. As a result, the main evidence concerning the success of reform in the water and sewerage sectors comes from case studies.

Case studies compare utility performance before and after privatization in a single country or city. The advantage of this type of study is that it is possible to look at a very broad range of country and enterprise characteristics and describe how transaction characteristics affected outcomes in far greater detail than would be possible in a cross-country or cross-utility study. However, these studies suffer from several notable problems. The first is simply that it is very difficult to assess with certainty why a reform succeeded or failed and even more difficult to determine whether the expected results would be different in cases other than the one being studied. In addition, sample selection bias is also a serious concern. That is, case studies are not selected randomly and the success or failure of reform might affect selection - particularly in the case of highly successful and highly unsuccessful reforms. For example, a particularly disastrous reform that generates large amounts of press coverage (e.g., the Cochabamba concession that was revoked) is probably more likely to be studied than a moderately successful reform in a similar country.

\section{I.1 Cross-country and cross-utility empirical analyses}

One approach compares the performance of private and public water utilities across and within countries. In principle, such analyses should provide the most rigorous test of the effect of private sector participation (PSP); indeed, we have learned a great deal about telecommunications reforms through empirical analyses of cross-country panel data. And water presents a potential advantage over telecommunications from an empirical point of view: while telecom reforms are often at the country level, water reforms are typically at the city or province level. As a result, it is possible to compare public and private utilities within the same country, something that should help deal with country-level institutional issues.

Unfortunately, it is difficult to exploit this advantage. In contrast to the telecommunications sector, where the International Telecommunication Union has collected detailed data on coverage, financial performance, service quality and prices for over 200 countries for over 25 years (for at least some indicators), it is difficult to find comparable crosscountry data on water and sewerage utilities. Consequently, statistical studies looking at the effect of private sector participation on the performance of water and sewerage utilities typically rely on small samples - making it difficult to find statistically significant results and making it

\footnotetext{
${ }^{8}$ See Estache and Kouassi (2002), which uses data from twenty-one African utilities from 16 countries for up to three years, and Estache and Rossi (2002), which uses data from fifty utilities from 19 countries in Asia for a single year (1995).
} 
impossible to control for the wide range of institutional, economic and physical factors that might affect sector performance.

Estache and Rossi (2002) use 1995 data from 50 water companies in 19 countries in Asia to explore the effects of ownership on utility performance. Twenty-two of the 50 companies had some form of private sector participation. The analysis attempted to estimate separately whether different types of PSP had different effects, controlling for whether the private participation involved a concession, administration (e.g., billing), or other services. The authors find no significant effects of any of the ownership variables. ${ }^{9}$ In a study of 21 water utilities in 16 countries in sub-Saharan Africa, Estache and Kouassi (2002) find that the private operators were more efficient than public operators in these countries. ${ }^{10}$ Neither of these studies fully controls for other factors that might affect both enterprise performance and private sector participation. ${ }^{11}$

One possible reason for the lack of significant findings is that private participation in water (or any given sector) does not happen in a vacuum. The same governance and institutional factors in a country that exacerbated problems in the water sector in the first place can cause problems under private ownership. Estache and Kouassi (2002) confirm this, finding that measures of institutional quality are an important factor in explaining the efficiency of water providers.

In addition to the cross-country studies, other studies have exploited the mix of private and public water operators within some developing countries. In 1998 the Chilean government began privatizing water companies, and within three years nearly three-quarters of all households received water service from private companies. Bitran and Valenzuela (2003) compare the performance of the privatized and public water systems, finding that private companies have invested far more than public companies and have kept prices lower. They state: "perhaps the most notable finding in this analysis is not the obvious differences between private and public companies, but the speed with which those differences have emerged." One area in which the public firms seemed to outperform the private firms is in reduction of unaccounted-for-water (UFW). The authors suggest that one reason for this discrepancy is that the state retained the firms in dryer regions, where water is more expensive. This explanation is consistent with Noll's

\footnotetext{
${ }^{9}$ Anwandter and Ozuna (2002) note that empirical analyses in industrialized countries were similarly split, with some finding positive effects of private sector participation, some finding better outcomes from public ownership, and some finding no significant findings either way.

${ }^{10}$ It is important to note that very few of the operators in Estache and Kouassi (2002) had any form of private sector participation over this period - apparently only two (see Table 1 in their paper).

${ }^{11}$ In particular, in the parts of the analysis that look at the effect of private sector participation on efficiency, both studies use cross-sectional rather than panel data (i.e., fixed effects are not included in that part of the analysis). Although Estache and Kouassi (2002) use a panel to estimate the inefficiency measures, the analysis that compares the effect of private sector participation on the inefficiency scores is cross-sectional. Further, neither study includes many additional variables to control for other differences in the institutional, economic or physical environment in which the utilities operate. Estache and Kouassi (2002) include two subjective indices to control for corruption and governance, while Estache and Rossi (2002) include measures of population density and percent of water from surface sources.
} 
(2002) point that repairing leaks is only worthwhile if the cost of doing is lower that the value of water that is saved.

In a second study, Garn et al. (2000) compare the performance of private water utilities in four small towns in Cambodia to municipal water utilities in four other randomly chosen similar towns. The private utilities performed far better on all measures of performance (related both to technical and financial performance and to consumer satisfaction). One concern about these results, however, is that this study does not fully control for the institutional, economic, and physical characteristics that might affect both utility performance and the likelihood of private sector participation. This is a particular concern in this study because the private operators approached the towns themselves, offering to operate the water systems. Since the firms probably did not approach the worst performing utilities in the least favorable environments, performance differences might reflect that the pre-existing conditions were better in those towns rather than that private sector participation improved utility performance. ${ }^{12}$

Although these studies do not provide strong evidence that private sector participation improves enterprise or sector performance, cross-country empirical studies do provide evidence on other aspects related to private sector participation. For example, two recent studies, Harris et al. (2003) and Guasch et al (2003), have looked at contract cancellations and renegotiations. The results from these studies suggest that reform might have been less successful that originally planned.

Despite the extensive press coverage given to some notable cancellations (e.g., in Tucumán, Argentina and Cochabamba, Bolivia - see Appendix), there have been relatively few outright cancellations of contracts with private operators - although at 3.5 percent of all projects, the cancellation rate is only second to that of toll roads (Harris, et al. 2003). Nonetheless, although cancellations are relatively rare, an enormous number of concessions have been renegotiated. ${ }^{13}$ Although renegotiation is a vital way of dealing with unforeseen circumstances and can benefit both sides to a contract, it is important to note that it can undermine the value of bidding for the market. If winning bidders believe that they will be able to renegotiate the terms of the contract, they have a strong incentive to bid strategically, planning on renegotiating the after they have won. Some observers have suggested that strategic behavior was a problem in the bidding for the 30-year concession contract in Buenos Aires (see Appendix).

Guasch et al. (2003) find that the existence of a regulator makes it less likely that concessions will be renegotiated, while the existence of price caps increases the probability of renegotiation. The fact that a regulatory authority decreases the likelihood of renegotiation highlights the importance of having a stable and coherent set of rules - one would expect contract renegotiations in environments that are inherently more uncertain. The increased probability of renegotiation that seems to come with price caps is potentially a cause for concern.

\footnotetext{
${ }^{12}$ Moreover, Garn, et al. (2000) note that the sales were not transparent and no regulatory regime has been established.

${ }^{13}$ Harris et al. (2003) report that 55 percent of all water concessions in Latin America and the Caribbean were renegotiated in the 1990s, while Guasch et al. (2003) report that 63 of 89 water concessions in that region for which there was data were renegotiated.
} 
Price caps are supposed to generate an incentive for cost-reduction by limiting the amount by which the utility can increase prices. If the price cap is renegotiated frequently it becomes little better than standard cost-of-service regulation, which has proven difficult as it requires that the regulator have enormous information about the firm's cost structure and affects the firm's investment incentives.

Although important, efficiency and price are only part of the story. As discussed previously, one important aspect of water and sewerage is the health externalities associated with these services. Although most of the studies discussed above have focused on the effect of private sector participation on utility performance and investment, Galiani et al. (2003) look at its effect on child mortality, using data from Argentina in the 1990s. They find that child mortality fell eight percent in regions that privatized their water systems, and that the effects were largest in the poorest areas. ${ }^{14}$

\section{I.2 Case study evidence}

In addition to the evidence from cross-country and within country comparisons, there is also a large literature based upon case studies of individual reforms. Appendix 1 provides short descriptions of many of the reforms discussed in the case study literature. Although there were some notable, and sometimes notorious, failures, most case studies find that private sector participation improved sector performance. The improvements are especially visible in measures of coverage, productivity, and water and service quality. In contrast to these successes, reform has often - but certainly not exclusively - been associated with price increases.

Connections and Production. In most cases, capacity expanded following the introduction of private sector participation. In all cases for which data were available (see Figure 1), the number of connections increased following the introduction of private sector participation and in eight of the ten cases, the total amount of water distributed or produced also increased. In one case where production did not increase, in the concession contract for Corrientes, this was due to a reduction in consumption due to metering and a reduction in unaccounted for water (Artana, et al. 1999).

\footnotetext{
14 The analysis is rigorous: the authors hone their findings by separating out mortality that can be caused by water conditions and mortality unrelated to water. Privatization was uncorrelated with mortality from non-water causes, but strongly correlated with mortality caused by water conditions, ruling out spurious correlations. Moreover, the measured effect may be underestimated since their water access data under-sampled the poorest areas, which appeared to receive the largest benefits.
} 
Figure 1: Connections (in thousands*), before and after reform.

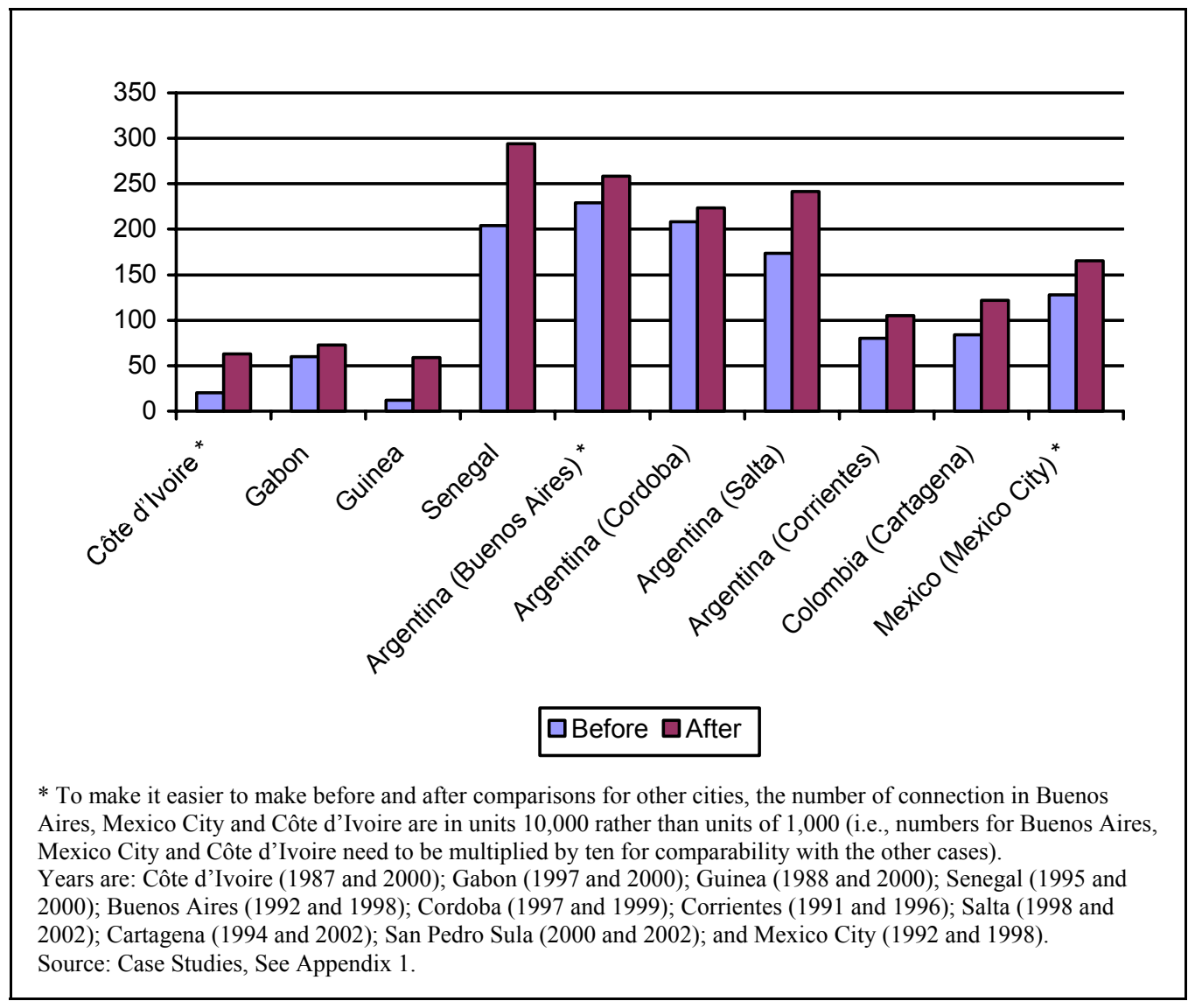

It is important to note that system expansion was not restricted to those cases where the private sector partners assumed responsibility for investment (i.e., through concession contracts or through full ownership). The reasons for increases in connections and production in cases of leases and management contracts varied between the individual cases. For example, in the Mexico City service contracts, the increase in the number of connections appears to be primarily due to the regularization of unregistered and illegal connections. Consequently, the increase in connections does not reflect a true increase in consumer welfare - most of the households were receiving piped water from the system prior to regularization. In some of the other cases, for example in Cartagena, Colombia and Conakry, Guinea, the investment was financed through loans from the World Bank. In this respect the increase in connections in these cases is not a direct result of the introduction of private sector participation. However, it is important to note that the governments of these countries would probably not have received any money from the World Bank in the absence of private sector participation - in both cases the poor performance of the public enterprises operating prior to reform and the non-transparent institutional environment would have apparently ruled out World Bank support under continued public ownership. ${ }^{15}$

\footnotetext{
${ }^{15}$ See the discussion of Guinea in Clarke, Ménard and Zuluaga (2002) and Cartagena in Nickson (2001b).
} 
In Côte d'Ivoire, the expansion following the 1987 reform, which gave the private operator responsibility for planning and implementing most sector investment (from a special government fund financed through the tariff), was not the result of loans from international organizations. In fact, whereas most investment before 1987 had been financed through borrowing from commercial banks and institutional financial institutions, the government decided that investment after 1987 should be financed from sector resources (i.e., through tariffs). Consequently, the large (and accelerated) increase in coverage occurred despite a large reduction in the resources available for investment. ${ }^{16}$ The increase, therefore, appears to be due to a reallocation of investment resources from increasing productive capacity towards expanding coverage after the private operator gained control over sector resources.

Productivity. In general, it is difficult to compare productivity across countries due to problems related to making international comparisons regarding valuing capital and output. One simple measure of productivity that can be compared across countries without making assumptions regarding exchange rates is the number of workers per 1000 connections. Although differences in factor prices and appropriate factor intensities means that comparisons between countries should be made carefully, it is probably easier to make comparisons within countries, across time. Based upon this measure, it seems that productivity generally improved following the introduction (or expansion) of private sector participation. In all cases where data were available, the number of workers per 1000 connections fell following the introduction of private sector participation (see Figure 2)

Figure 2: Workers per 1000 Connections, before and after reform.

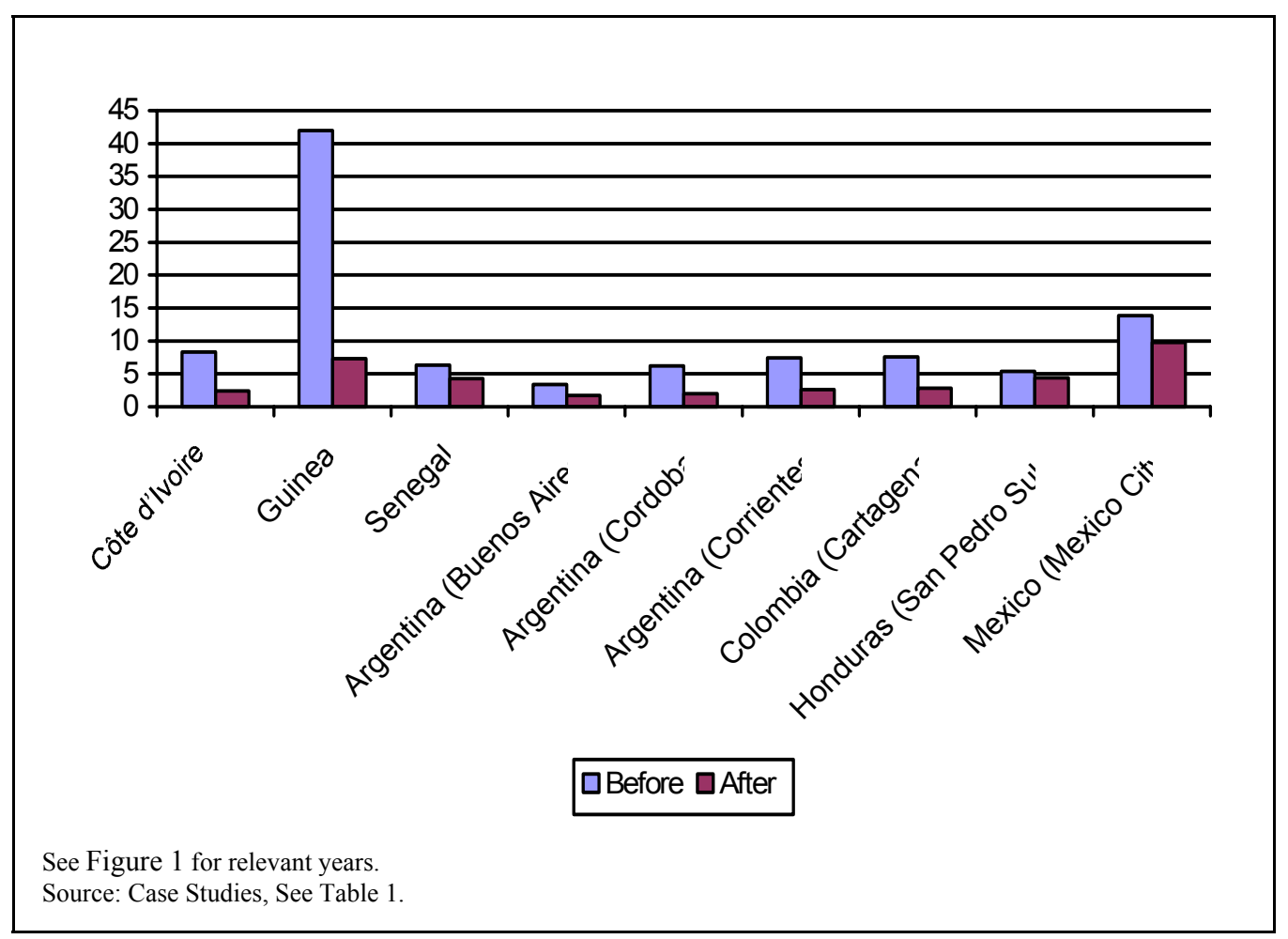

${ }^{16}$ See Ménard and Clarke (2002a). 
It is important to note that this does not appear to be simply due to the private operator reducing the size of the workforce. First, as noted previously, the introduction of private sector participation was generally associated with an increase in coverage and, therefore, the ratio could fall without a decrease in the number of employees (see, e.g., the case of Gabon, described in Trémolet and Neale 2002). However, in many of the case studies, there were significant reductions in the number of employees. Furthermore, even when the total number of employees stayed about the same in the medium-term, there were often significant workforce reductions (often through voluntary agreements with workers) following the reform (see, e.g., the case of Guinea, described in Ménard and Clarke 2002b). That is, even if the private managers want roughly the same number of employees after reform as were in place before reform, they may want to realign the workforce in other ways (e.g., hiring more workers in commercial areas and reducing the number of engineers or technicians). Consequently, even if reform results in an overall expansion of the workforce in the medium term, layoffs might be necessary in the near term.

Prices. Despite the improvement in productivity associated with the introduction of private participation found in most of the case studies, prices often increased following reform. For example, in Chile, water and sewerage rates increased 40 percent for privatized utilities compared to only about 20 percent for non-privatized utilities (Bitran and Valenzuela 2003). Although this might seem puzzling given that productivity appears to have increased in most cases, this is probably not surprising given that water prices have often been set below cost in developing countries (World Bank 1994).

Further, for several reasons, the "headline" price changes announced at the time of privatization might not reflect the true medium-term effect of reform on prices. First, since prices are often adjusted frequently following the introduction of private participation, often during contract renegotiations, it is difficult to assess the medium-term effects of reform in the absence of detailed information on the price changes that would have occurred under public ownership. Second, private participation is often associated with other changes that affect the amounts that consumers pay - metering often increases, the tariff structure is often revised, and houses are often billed differently. These changes affect the actual price that consumers pay and make it very difficult to compare pre- and post-reform prices.

In Buenos Aires, for example, households paid a fixed fee based upon various factors such as the size of the property and whether the property was residential or nonresidential. Although the complicated structure was retained following the introduction of private participation, the private company reclassified about 11 percent of 'residential' properties as 'non-residential' and corrected the reported size of built areas for others. This resulted in fee increases for about 425,000 of the utility's 2.5 million customers. Given that private operators have a strong incentive to increase revenues, it seems plausible that many of these changes will increase consumer prices. Finally, informal connections are often regularized, increasing prices for these users. Since these users received service (although possibly an inferior level of service), the effective price that they pay for this service will be higher after regularization. In summary, although it is difficult to estimate the effect that these factors have on prices, even in individual cases, it seems plausible that headline price changes will usually underestimate the true impact of private sector participation on prices. 
There does not appear to be an easy way of handling tariff increases. For example, raising the price at (or close to) the time when private sector participation is introduced appears to have contributed to several contract cancellations (e.g., in Cochabamba, Bolivia and Tucumán, Argentina). This has led some observers to suggest that it is better to raise prices before the introduction of PSP (see, e.g., Nickson and Vargas 2002). On the other hand, although raising prices before introducing PSP might reduce public opposition to PSP per se, it also might focus public opposition to PSP and stop reform before it even starts (consider, for example, the failed reform in Pune, India - see Appendix 1).

Another possible solution is to raise prices slowly over time, allowing the private operator to improve and expand service before having to raise prices and allowing customers to adapt to higher prices slowly. This approach, however, has some drawbacks. Most notably, one of the main political motivations for introducing private sector participation is to reduce the cost that the water utility imposes on the state budget and also to provide resources for system expansion. That is, the extent and speed of improvements in coverage and quality might depend upon resources being quickly available for investment and maintenance - something that is more likely if tariffs were raised at the time of reform. Further, private investors might not find government promises of subsidies credible - especially given that many governments in lowincome countries fail to pay even for their own water consumption.

Water and Service Quality. In addition to efficiency, coverage, and prices, an additional aspect of water and sewerage is the health externalities associated with these services. Although most case studies do not explicitly look at the effect of private participation on health outcomes, there are at least two reasons to expect that they might improve. First, as discussed above, private participation is often associated with increased coverage. Given that piped water is associated with improved health (in terms of diarrhea, child height, and child weight) (Esrey 1996, Jalan and Ravillion 2001), it seems likely that private participation has improved performance along these dimensions. Further, although few case studies provide detailed information on water quality, most suggest that it improved and some (e.g., studies in Salta, Argentina and Conakry, Guinea) show that physical, chemical, and bacterial quality improved following privatization. One area where there was little consistent evidence of improved performance is unaccounted-for water. This might partially reflect the poor information on unaccounted for water in many publicly operated systems. Unless the public operator meters consumption, it is very difficult to know how large a problem unaccounted-for water was before reform.

\section{EMPIRICAL ANALYSIS}

As discussed above, there is very little empirical analysis of the effects of PSP in the water sector in developing countries. In this section we use household-level data from three countries in Latin America (Argentina, Bolivia, and Brazil) to assess the effects of PSP on water and sewerage connections.

Our approach has several advantages over the existing literature:

- The household surveys (described in more detail below) are conducted in a fairly consistent manner and ask very similar questions across countries. 
- The surveys are conducted over multiple years, allowing us to create datasets that include information on single utilities before and after privatization.

- The surveys ask questions about water and sewerage access, allowing us to explore the effects of privatization on both utilities, rather than only on water as most studies are forced to do.

- Because these surveys are conducted in many cities across each country, we also include data from cities that did not privatize their water systems, allowing us to include control groups for comparison.

- The surveys contain information on household education and income, allowing us to explore the effects of privatization on the poor and disadvantaged households.

While the data offer great improvements over other datasets, they have some shortcomings. In particular, they have no information on household spending on water and sewerage services, meaning that we cannot assess the effects of price changes. They also do not provide any information on the efficiency of the water company (e.g., labor productivity or unaccounted-for-water). The implication of this is that while we can look at the effects of privatization on coverage over time and compared to cities that did not privatize, it is impossible to derive welfare changes from these data. In the next sub-sections we discuss the data, how we analyze it, and the results.

\section{II.1 Data and Analysis}

Our objective was to assemble a dataset that would allow us to assess household access to piped water and sewerage. Throughout the 1990s many Latin American countries participated in an initiative to conduct multi-year household-level surveys. ${ }^{17}$ During the same time period, many municipalities in Latin American countries introduced PSP in water supply and sewerage.

Appendix 2 describes in detail how we put together our dataset and the assumptions and choices we had to make in order to assemble it. Essentially, though, we had two primary data challenges. First, we identified municipalities that introduced PSP and match those to the surveys that would provide us with data from before and after the privatization. To ensure useful comparisons, we chose countries where we could have, at a minimum, data from one year before, and two to five years after privatization. Second, the original survey data had to be constructed so that it was possible to identify relatively small geographic regions in order to capture areas affected by PSP.

\footnotetext{
${ }^{17}$ This initiative, the Programa para el Mejoramiento de las Encuestas y la Medición de las Condiciones de Vida en América Latina y el Caribe (the Program for the Betterment of Surveys and the Measurement of the Living Conditions of Latin America and the Caribbean, or MECOVI), is a joint initiative of the Inter-American Development Bank (IDB), the International Bank for Reconstruction and Development (IBRD), and the Economic Commission for Latin America and the Caribbean (ECLAC). Its central objective is to aid Latin American countries in generating adequate and high quality information regarding living conditions.
} 
These fairly stringent criteria left us with a rather short list of countries: Argentina, Bolivia, and Brazil. While this is a small number of countries, however, multiple cities and provinces in each country introduced PSP. Moreover, within each of these countries we matched cities and provinces that introduced PSP to "control" cities and provinces - areas that retained public ownership of their water systems - where possible. We matched regions based on population, as that variable was the most widely available at the relevant geographic levels.

In addition to access overall, we are interested in the effects of PSP on access by the poor. We used two measures to identify poor households: education of the household head and income. While household income is probably the best way to identify poor households, not all respondents report this information. Education, which is typically correlated with income, simply provides an additional window on the effects of PSP by socioeconomic status. Appendix 2 explains how we defined these variables for each country.

For each city and year we identified the share of households with access to piped water and the share of households with flush toilets. ${ }^{18}$ To evaluate the distributional effects, we also identified the share of households with low incomes and heads with little education. The exact definitions of "low incomes" and "little education" that we used varied somewhat across countries due to the fact that small sample sizes in smaller cities made certain comparisons impossible. We explain each definition more carefully when we discuss the result by country, below.

Our final dataset has information from 18 cities that introduced some form of PSP in the 1990s, and 28 controls cities that never privatized. For Argentina we have survey data for 1995, 1999, 2000, 2001, and 2002; for Bolivia 1995, 1999, and 2001; and for Brazil 1995 and 2001.

Table 1 lists the cities, the year of PSP, and provides a brief description of the PSP arrangement. Table 2 shows all the cities we identified, including the controls, and their populations. It is important to emphasize that an observation in the dataset is a city-year, and a variable is the share of households in that city reporting that they have water and sewerage access (access to infrastructure overall, access to infrastructure by education and income).

To evaluate the effects of PSP on water and sewerage access we compared access before and after privatization in each city and relative to access in cities that retained public control of their water and sewerage utilities. We discuss the results below.

\section{II.2 Results: Graphs by Country}

The results, in general, are fairly consistent across the three countries. Access to both water and sewerage tended to improve in areas with PSP following privatization, consistent with the case study literature discussed above. However, access in cities that retained public ownership also tended to improve over those same years. Although access fell in some cities over the periods that we studied, this does not necessarily imply that the total number of

18 More accurately, we consider a household to have a flush toilet — and thus sewerage services—if the household has drainage to a "public network or sewer" in Argentina, to the sewer in Bolivia, and to a "sewerage network OR septic tank linked to sewage collection" in Brazil. 
connections fell - urban population was growing in many of the cities in our sample and, therefore, the number of connections needed to increase just to keep pace with population growth. ${ }^{19}$

The results concerning coverage also hold across socioeconomic lines: access by the poorest households tended to improve or remain relatively constant following the introduction of PSP. However, changes in coverage for poor households did not appear any different in areas with PSP than it did in those with public access. Still, each country presented unique challenges in aggregating the data for analysis while discarding as little information as possible.

\section{II.2.1 Brazil}

Brazil yielded the simplest data. Here we identified two regions, one a province and the other its capital city, that introduced PSP. Both regions entered into joint ownership agreements in 1998. Eleven cities and provinces served as controls. Household surveys conducted in 1995 and 2001 provided us information from several years before and several years after PSP. We averaged the access figures from the two areas that entered into joint ventures, and also averaged the access figures for our control areas.

19 Between 1995 and 2001, piped water coverage decreased by more than 2 percent in 3 Bolivian cities in the dataset: Oruro, Sucre, and Trinidad. Between 1992 and 2001, the Bolivian population grew nearly 29\%. In Oruro, population growth was only $9.71 \%$, but Sucre and Trinidad saw population growth of more than $47 \%$ and $31 \%$, respectively. Drops in water coverage, at least in the latter two cities, may reflect the failure of connection growth to keep pace with population growth.

Between 1995 and 2001 (1999-2001 in Argentina), the sewerage coverage of 7 cities decreased by more than 2 percent. In 2 of those cities, population growth resembled the national average (11\% in Argentina and 29\% in Bolivia). In the remaining 5, it was above average: roughly $40 \%$ above average in 1 city (Parana), $75 \%$ in another (Tarija), 100\% in 2 cities (Santiago del Estero and Gran Resistencia) and 150\% above average in the fifth (Catamarca). Drops in sewerage coverage may reflect a failure of connection growth to keep pace with population growth. 
Figure 3

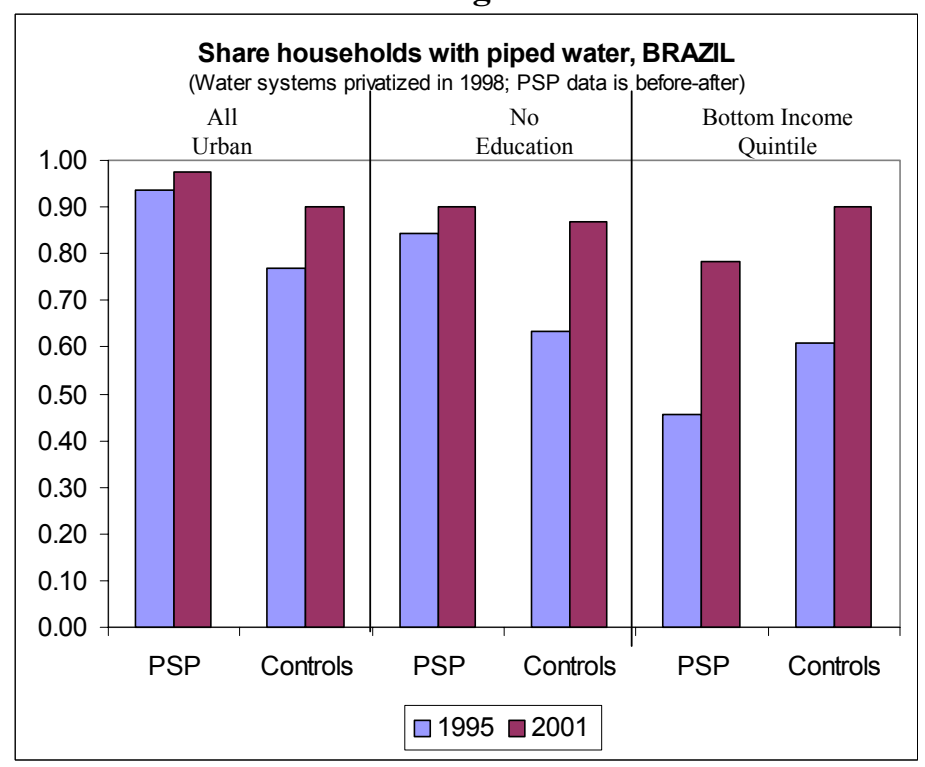

Figure 3 compares household access to piped water before and after entering into the joint ventures, and compares that performance to the control areas. The Figure reveals that access, already fairly high, improved somewhat following the introduction of the private sector. It is also clear, however, that access to piped water in the control areas, which was lower than in the areas that would ultimately experience PSP, improved by more than coverage in the areas that introduced PSP. Access to piped water by the poor, meanwhile, seemed to improve fairly substantially in both the areas that introduced PSP and in the control areas.

Figure 4

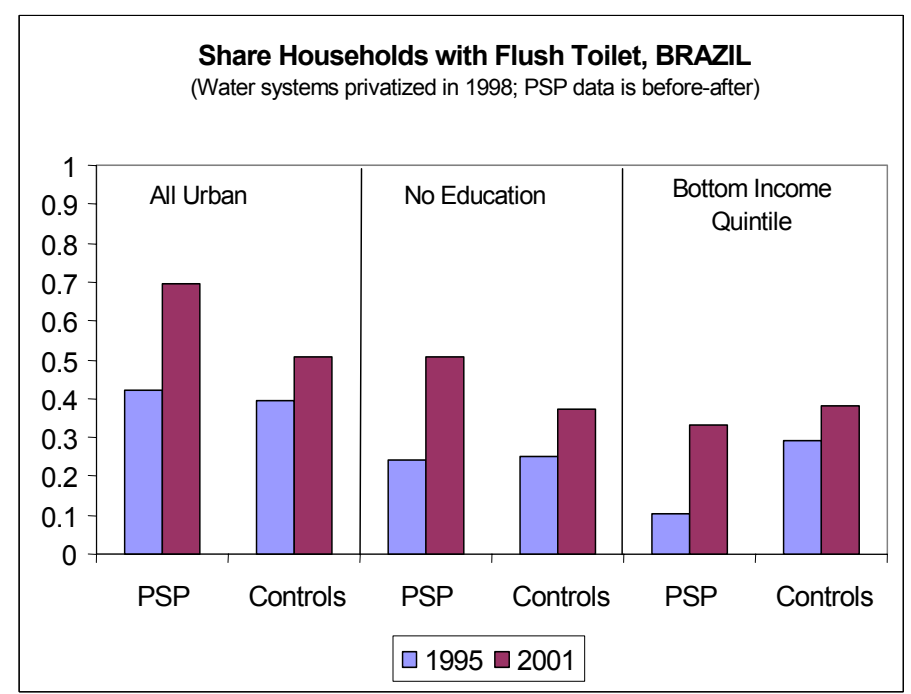


Figure 4 shows the similar analysis for access to flush toilets. The general picture here is the same: access improved under PSP and under public provision. In this case, however, the sewerage gains under PSP appear to be better both overall and for the poor, who saw access rates more than double while poor households in the control areas saw only minor improvements.

\section{II.2.2 Bolivia}

Three cities in our sample in Bolivia introduced PSP in the water and sewerage sectors: La Paz, El Alto and Cochabamba. La Paz and El Alto, privatized in 1997, were under the same concession agreement, however, so we treat them as a single city (La Paz/ El Alto). The government of Cochabamba entered into a 40-year concession agreement in 1999, but it was cancelled five months later after civil unrest in response to tariff increases. Household surveys were conducted in 1995, 1999, and 2001. These data allow us to see the before-after comparison for La Paz/El Alto, and compare it to control cities and the failed privatization in Cochabamba.

Figure 5

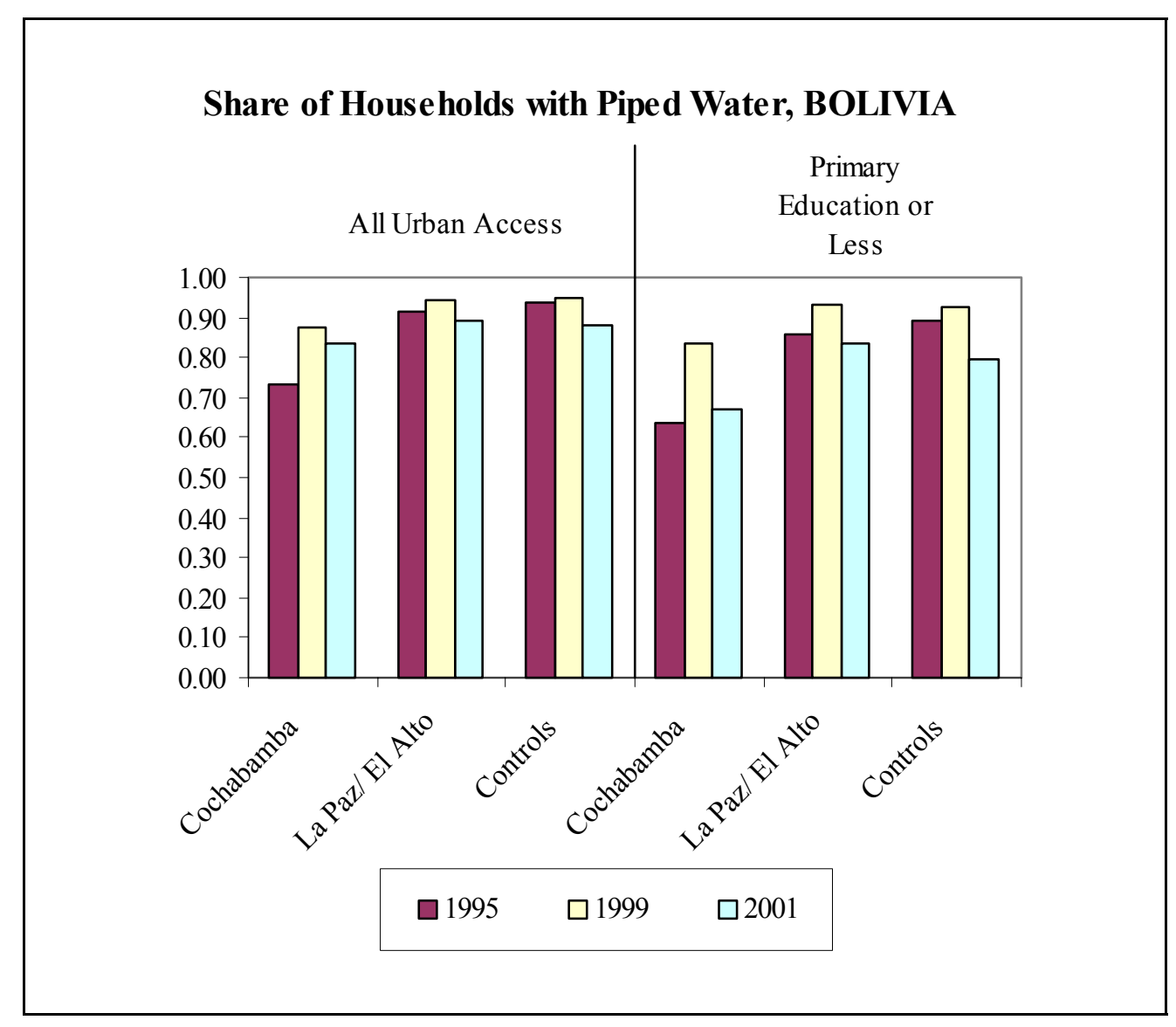

Figure 5 shows household access to piped water in La Paz/ El Alto, Cochabamba, and our control cities for 1995, 1999, and 2001. We use education as a proxy for income, as the small sample size made income comparisons impossible. The figure shows a general improvement in the late 1990s in all cities followed by modest declines in coverage between 1999 and 2001. There is no evidence that La Paz / El Alto fared particularly better or worse than did the other cities. 
Figure 6

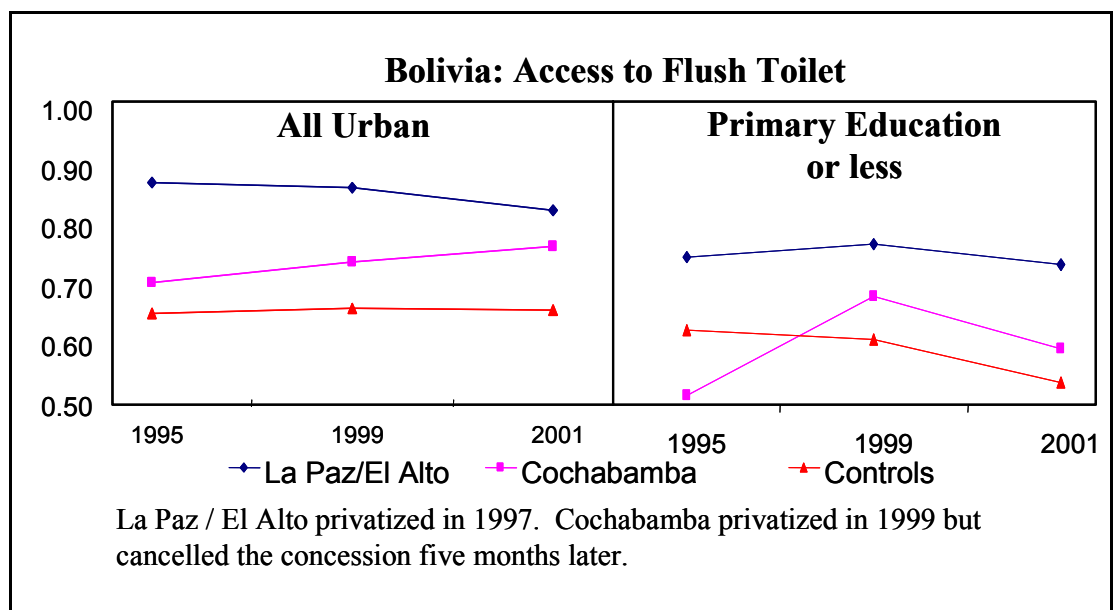

Figure 6 shows access to sewerage. This figure demonstrates first that at least in one respect La Paz / El Alto was in better shape prior to its privatization than were the other cities. Gains in overall sewerage access seemed to continue following Cochabamba's failed privatization, but poorer people lost ground after the cancellation, both in absolute terms and relative to other cities in Bolivia.

\section{II.2.3 Argentina}

Among Latin American countries, probably Argentina most actively embraced private sector participation across all major sectors of the economy. Water was no exception. In our sample we identified 13 cities and provinces that introduced PSP. While it is impossible to match some of the cities - such as Buenos Aires - to a control group, we were nonetheless able to identify six controls to match to the smaller cities.

Our household data comes from surveys in 1995, 1999, and 2002. Privatizations, meanwhile, began in 1991 (Corrientes was the first city in our sample to privatize) and continued until 2002 (when La Rioja privatized). Our data allows us, therefore, to look at access from 1995 -2002 for cities that privatized before that time period and thus were privately run throughout; at the very beginning of the time period (1995); sometime during the time period - and thus allowing a before-after comparison; one city that privatized at the end; and cities that never privatized. For simplicity, we aggregated data from cities that privatized in the same time period, except for Gran Buenos Aires and Buenos Aires province, which are each too large to meaningfully combine with other regions.

Figure 7 shows urban access to piped water in cities throughout Argentina. Most striking is the near universal coverage of piped water in all these cities. With a few exceptions, the changes over the time period are too small for us to rule out sampling error. 
Figure 7

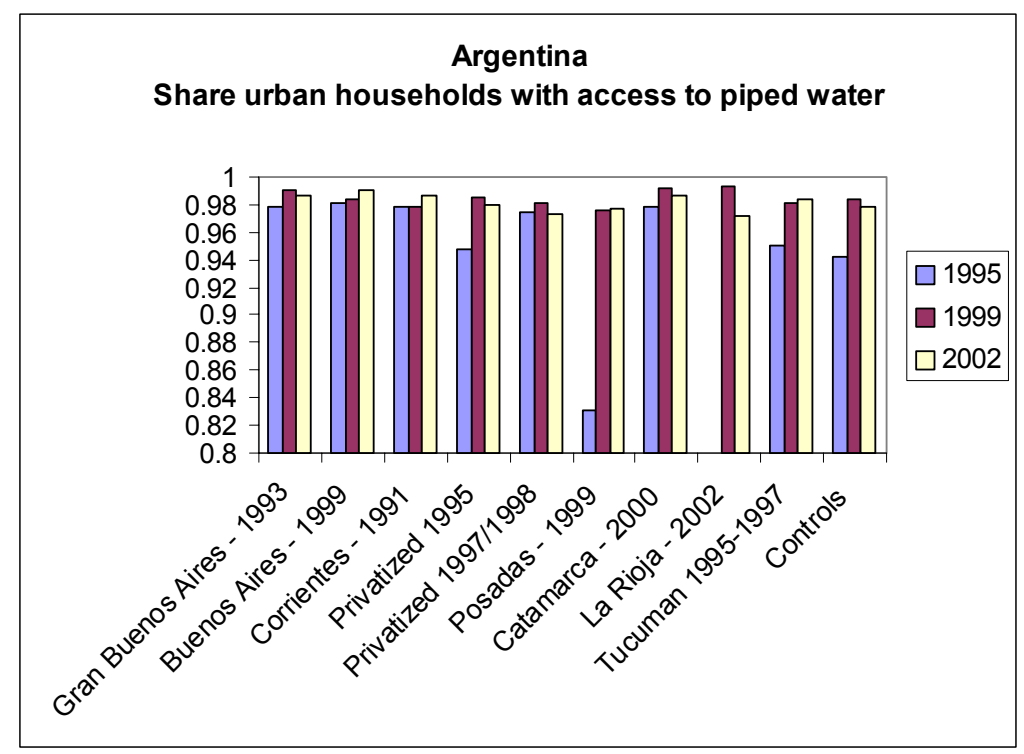

The exceptions include Posadas, privatized in 1999, and possibly the cities privatized in 1995 (Santa Fe-Rosario and Formosa), Tucumán, and the control cities. Posadas experienced a large jump from about 82 percent coverage in 1995 to 97 percent coverage by 1999 . Because Posadas was privatized in 1999 it is difficult to attribute this improvement to the privatization itself, but it may have resulted from improvements in anticipation of privatization (perhaps in order to make the concession more attractive). Moreover, the cities that saw some improvement did not, with the exception of Posadas, seem to improve by more than did the cities that retained public control of their water systems.

Figure 8 shows access to piped water by households in the bottom income quintile. This sample suffers from a relatively small sample size in some cities, as is evident by the few cases of 100 percent coverage. Nonetheless, the figure still demonstrates that even poor households in these cities in Argentina had relatively good access to piped water. The general trends here are the same as in the aggregate, with some improvements over time, but not generally better in cities with PSP than in cities with public water systems. 
Figure 8

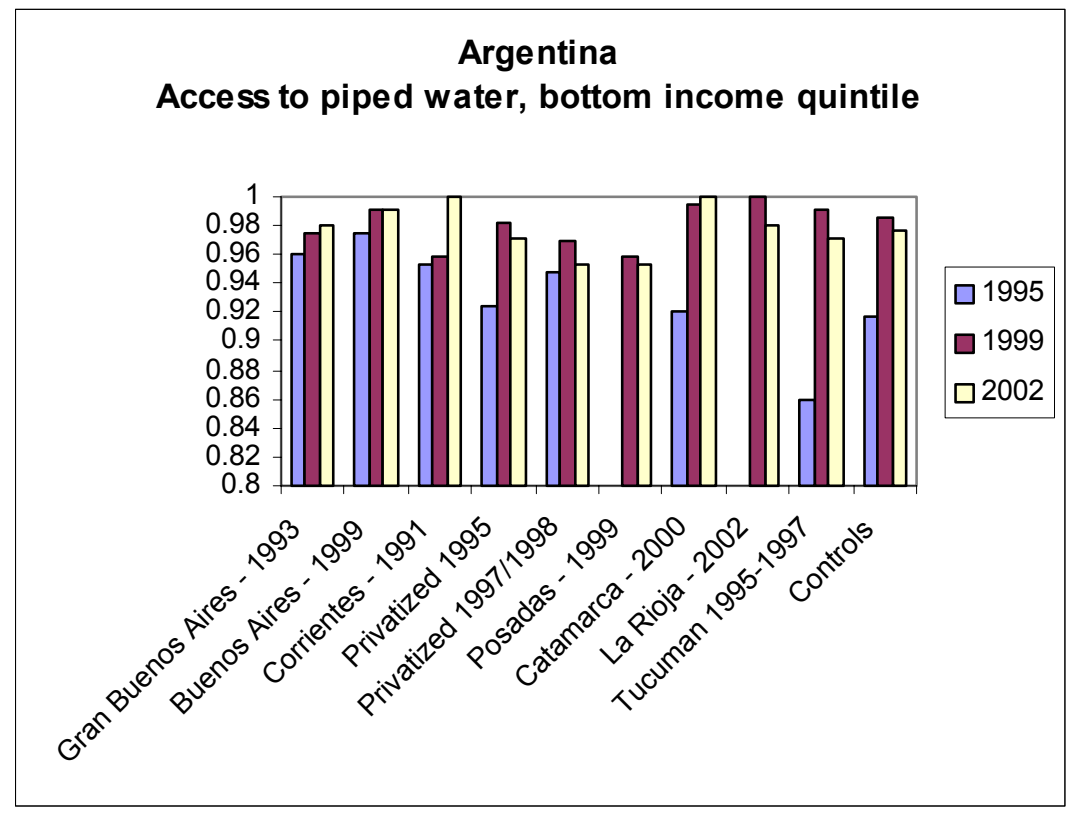

Our sewerage data are not quite as comprehensive. The household surveys did not contain questions regarding sewerage connections in 1995, eliminating our earliest time period. The result is that we have true before-after data only for one city, Catamarca, which privatized its water system in 2000. Figure 9 shows the aggregate sewerage connection data.The figure demonstrates that sewerage coverage is, in general, not nearly as widespread as is piped water. It also demonstrates overall very little change between 1999 and 2002. The figure shows small increases in coverage in Buenos Aires (province) and Posadas, which both privatized in 1999, and a small decrease in coverage in Catamarca. Connections in the control cities increased slightly. 
Figure 9

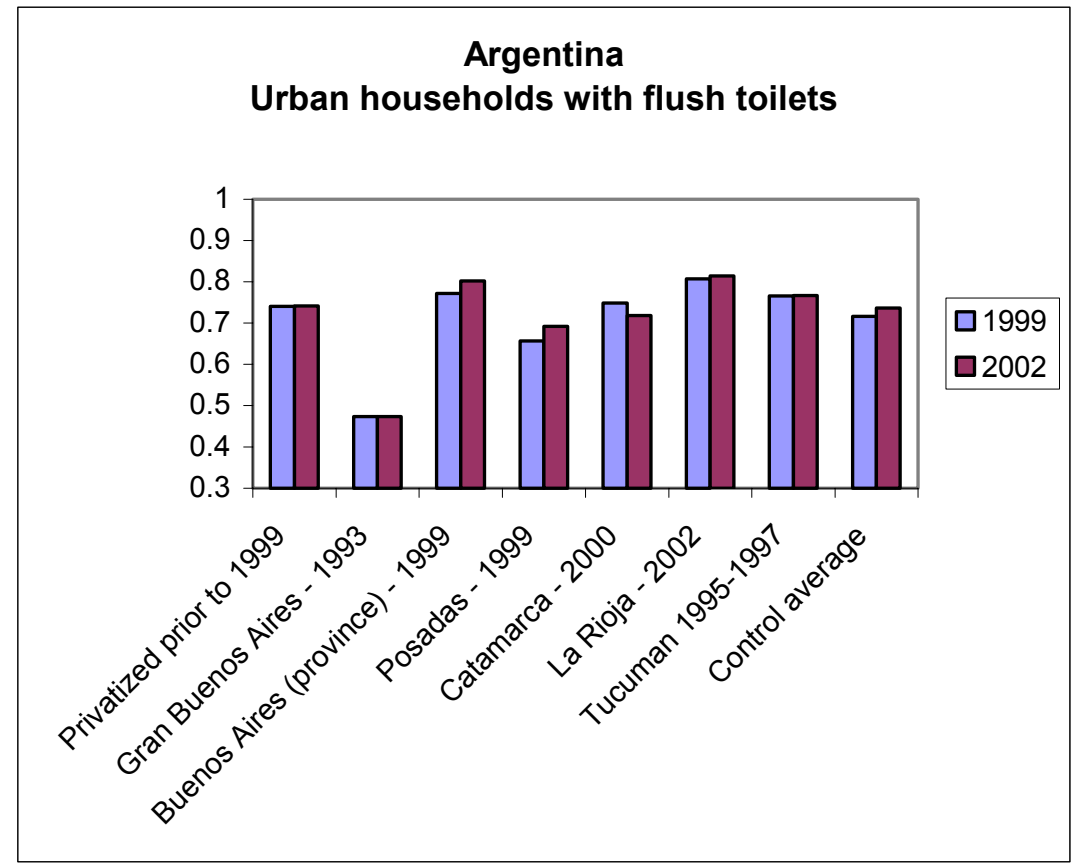

Access to sewerage remained relatively constant among households in the poorest income quintile, as well, with a few exceptions. Catamarca saw a substantial decrease in connections after privatization, while La Rioja saw a fair increase in connections prior to privatization. Connections in control cities among the poor increased slightly. 


\section{Figure 10}

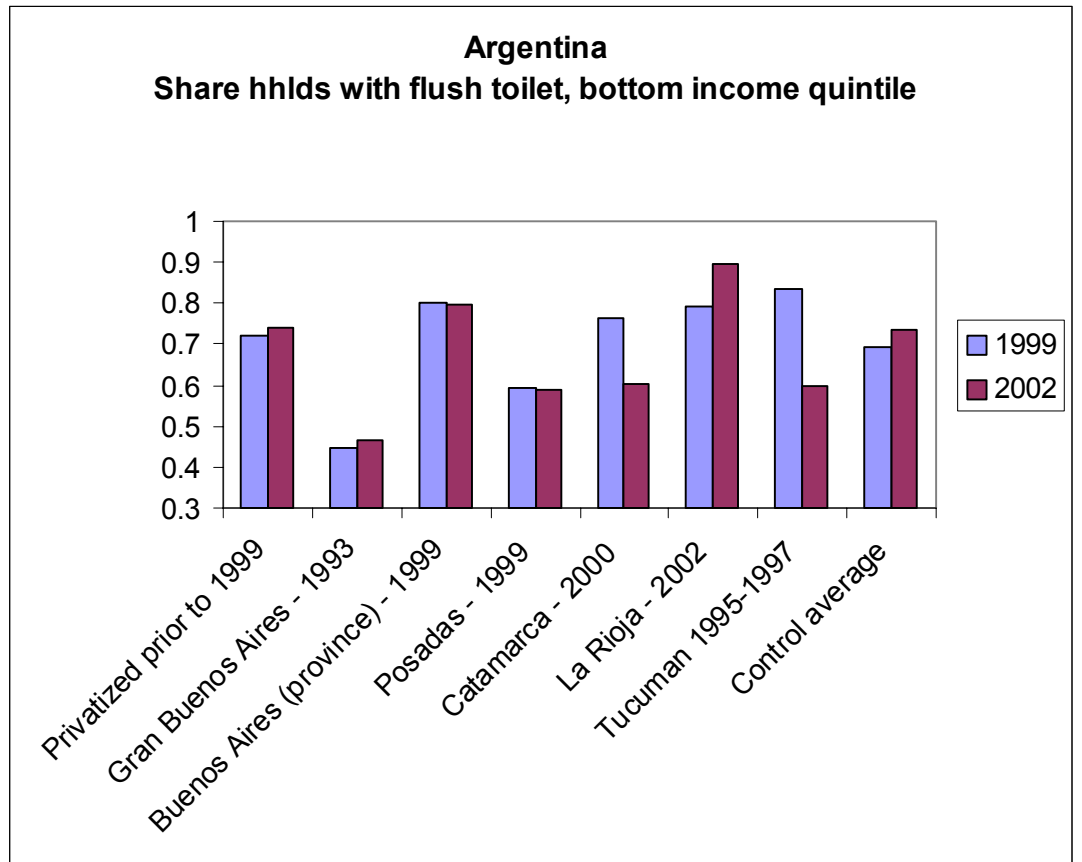

\section{II.3 Results: Empirical Analysis}

The figures presented above are suggestive, but the data allow us to go a step further and analyze them econometrically. In particular, we estimate several versions of equations (1) and (2), below.

(1)

water connection $_{i t}=\beta_{0}+\alpha_{t}+\beta_{1}\left(\right.$ private $\left._{i t}\right)+\beta_{2}\left(\right.$ population $\left._{i t}\right)+\beta_{3}\left(\right.$ income $\left._{j t}\right)+$ $\beta_{4}\left(\right.$ control $\left._{i}\right)+\varepsilon_{i t}$

(2)

$$
\begin{aligned}
& \text { sewerage connection }_{i t}=\beta_{0}+\alpha_{t}+\beta_{1}\left(\text { private }_{i t}\right)+\beta_{2}\left(\text { population }_{i t}\right)+\beta_{3}\left(\text { income }_{j t}\right)+ \\
& \beta_{4}\left(\text { control }_{i}\right)+\varepsilon_{i t}
\end{aligned}
$$

An observation is a city- (or region-) year. The dependent variable is as described above: the share of the urban population with piped water and sewerage connections. Private is a dummy variable indicating private sector participation. Population is the population of the city according to census data closest in time to the year $t .{ }^{20}$ Income is the country-level per-capita GDP (in constant 1995 dollars) in the survey year. Control is a dummy variable indicating that the city or region retained public ownership of the system. We add variables slowly as we estimate the equations to see how controlling for various factors affects the results.

20 City or province population are not available for all places in all years. Table 2 provides more details on the years for which we have population data. 
Table 3 shows the results of estimating equation (1). The first column of the table shows that privatization is positively and significantly correlated with piped water coverage when controlling only for population and income. Including year dummies causes the estimate to become statistically insignificant and smaller in magnitude, though it remains positive. Adding in the control dummy variable, however, changes the results quite a bit. The coefficient on private turns negative, though it remains statistically insignificant.

In the final column of the table we test whether the type of privatization contract matters. In Bolivia and Argentina PSP involved concessions, but in Brazil PSP involved joint ownership. We find a negative coefficient on the concession dummy variable and a positive coefficient on the joint ownership variable, though neither comes close to being statistically significant. It is not clear, however, whether the lack of significance is due to a true lack of correlation or whether it is due to the relatively small sample size (i.e., we have only four observations of joint ownership).

Table 4 shows the results from estimating equation (2) in the same manner as described for equation (1). The results are essentially identical: PSP is positively and significantly correlated with coverage until one controls also for time trends and compares to cities that never privatized. In the presence of these controls, the analysis does not reveal any statistically significant correlation between private sector participation and coverage rates.

\section{CONCLUSIONS AND DiscuSSION}

The existing evidence on the effects of privatization in the water sector is spotty, at best. In general, cross-country empirical studies have been fairly inconclusive, possibly because comparable data are so scarce, while single-utility case studies tend to find improvements, especially in the number of connections and labor productivity. We use data from householdlevel surveys to generate consistent, comparable data across countries and municipalities to look at the evidence on coverage in greater detail. These data allow us to explore connection rates for piped water and sewerage before and after PSP and to compare those rates to comparable cities that did not introduce PSP.

With respect to coverage, our results are broadly consistent with the existing case study literature; we find that piped water and sewerage coverage generally increased following the introduction of private sector participation. However, coverage also improved in cities that did not introduce PSP and, consequently, there is little evidence that PSP itself improved coverage. Because case studies do not consider cities other than the one under investigation, they may mistakenly attribute better coverage to PSP without considering what was likely to happen in the absence of PSP.

On the other hand, although we do not find that PSP improves coverage, we also do not find strong evidence that the poor were significantly harmed by privatization, at least in this respect. Just as in the aggregate, trends in connection rates for poor households were similar in cities that did and did not introduce PSP.

Although these results suggest that PSP did not directly improve coverage, they are also consistent with an alternate hypothesis: that benchmark competition with private utilities 
encourages utilities that remain publicly owned to improve their own performance. Research on telecommunications suggests that introducing real competition, rather than privatization, is mostly responsible for the improvements observed in the sector in recent years. Introducing competition in the water sector, however, is difficult as discussed above. In these cases, it is possible that competitive pressures could come from firms competing for concessions (competition for the market) or from popular pressure for residents served by public companies for their water system to perform as well as their neighbors' systems (benchmark competition).

There is little evidence that competition for the market has been successful in developing countries. A first problem is that there are often very few bidders for many contracts, partly reflecting the fact that several large private firms dominate private sector participation in water and sewerage (see Silva, et al. 1998). An additional problem associated with competition for the market is that many contracts - up to two-thirds in Latin America - are renegotiated following the introduction of private sector participation. The high number of renegotiations is a concern because it suggests that there is a strong potential for strategic behavior when bidding for contracts; firms can bid with the expectation that they will be able to renegotiate unfavorable contract provisions after they have won the contract. For example, in cases where contracts were bid on price, price reductions have often been quickly eroded during contract renegotiations (e.g., in Buenos Aires and Tucumán).

It is possible, however, that our data demonstrates the effect of benchmark competition. As one city reforms its water systems, other cities feel pressure to similarly reform. In this case, one might expect to see comparable changes among cities that privatized and cities that did not. This hypothesis, though, even if true, demonstrates potential benefits of competition and not of privatization, per se. Moreover, it does not explain why benchmark competition between cities was not a potent force prior to privatization.

While our information on connection rates is more comprehensive than most existing studies, we lack enough information to make more definitive statements about the effects of privatization on consumers. In particular, we currently have no information on tariffs or on what households pay for water or sewerage. We also do not know whether connections to the water system are formal, illegal, or metered, and we do not know whether that status changed with privatization. Further, as in most case studies, we do not have any information on direct or indirect subsidies before or after privatization. Absent such information, we cannot estimate the welfare effects of reform.

Such additional information would be important to uncover given that one of the most difficult issues with which reform must contend is that of tariffs. In many countries, tariffs were set well below nearly any measure of long-run cost prior to reform. Therefore, they often had to be increased, even after the gains in productivity that are evident in the case study literature are taken into account. This has proven to be extremely unpopular-notwithstanding contingent valuations surveys that suggest that people are often willing to pay high tariffs for improved 
service and water quality - and appears to have been one of the main problems in the most notorious contract cancellations (see Appendix 1). ${ }^{21}$

In summary, water privatization has proven to be especially controversial and difficult. To date there has been little empirical work evaluating its effects. We use household-level data to explore the effect on water and sewerage coverage over time (before and after privatization) and across cities, including compared to control cities that never privatized. While connections appear to have generally increased following privatization, the increases appear to be about the same as in cities that retained public ownership of their water systems. In other words, the analysis provides little evidence that privatization itself generated improvements in access. However, contrary to fears, there is also no evidence that the poor served by privatized firms are supplied any worse than the poor served by public water utilities.

\footnotetext{
${ }^{21}$ Even when contracts have not been cancelled, tariff increases have often been controversial. In Guinea, for example, a lease contract was not renewed after it expired, primarily due to discontent that resulted from the large tariff increase that followed the introduction of private sector participation. This occurred despite the fact that most performance indicators in Guinea improved following the introduction of private sector participation - in particular, coverage increased and service and water quality improved.
} 


\section{TABles}

\section{Table 1}

\begin{tabular}{|c|c|c|c|}
\hline $\begin{array}{l}\text { Geographical Area } \\
\text { with PSP }\end{array}$ & $\begin{array}{l}\text { Year } \\
\text { of PSP }\end{array}$ & $\begin{array}{l}\text { Year PSP } \\
\text { cancelled }^{22}\end{array}$ & Description of Private Sector Involvement \\
\hline $\begin{array}{l}\text { Gran Buenos Aires, } \\
\text { Argentina (city) }\end{array}$ & 1993 & & $\begin{array}{l}\text { In 1993, local authorities of the city of Gran Buenos Aires, granted a } 30- \\
\text { year concession of water and sanitation services to the private firm } \\
\text { Aguas Argentinas. The contract was bid based upon the price reduction } \\
\text { that the winning bidder would implement, resulting in a } 27 \text { percent price } \\
\text { decrease. }\end{array}$ \\
\hline $\begin{array}{l}\text { Buenos Aires, } \\
\text { Argentina } \\
\text { (province) }\end{array}$ & 1999 & 2002 & $\begin{array}{l}\text { The local water operation of the province of Buenos Aires was } \\
\text { purchased in } 1999 \text { for US } \$ 430 \mathrm{~m} \text { by Azurix, an international subsidiary } \\
\text { of Enron (US). In October } 2001 \text {, the now-bankrupt US energy company } \\
\text { announced that it would withdraw from the contract as of January } 2002 \text {. } \\
\text { The provincial government took over the firm through state-owned } \\
\text { Aguas Bonaerenses (EIU). }\end{array}$ \\
\hline $\begin{array}{l}\text { Gran Cordoba, } \\
\text { Argentina (city) }\end{array}$ & 1997 & & $\begin{array}{l}\text { In 1997, the provincial government of Cordoba signed a } 30 \text {-year } \\
\text { connection contract with Aguas Cordobesas, a private company owned } \\
\text { by Suez-Lyonnaise des Eaux and domestic investors. The concession } \\
\text { contract was for water services only (and did not include sanitation). }\end{array}$ \\
\hline $\begin{array}{l}\text { Santa Fe-Rosario, } \\
\text { Argentina (cities) }\end{array}$ & 1995 & & $\begin{array}{l}\text { In 1995, the provincial government of Santa Fe granted a } 30 \text {-year } \\
\text { concession to Aguas Provinciales de Santa Fe, a private consortium of } \\
\text { which Suez Lyonnaise de Eaux owned just over } 50 \% \text {. }\end{array}$ \\
\hline $\begin{array}{l}\text { Tucumán, } \\
\text { Argentina (city) }\end{array}$ & 1995 & 1997 & $\begin{array}{l}\text { In 1995, the provincial government of Tucumán granted Aguas del } \\
\text { Aconquija SA (CAA), a subsidiary of Vivendi, a 30-year concession to } \\
\text { supply water and sanitation services. The privatization contract was } \\
\text { awarded through competitive bidding to the company that agreed to } \\
\text { allow the largest price reductions, subject to management and } \\
\text { investment requirements set by the provincial government. Problems } \\
\text { quickly developed, however, and in 1997, the contract was rescinded. }\end{array}$ \\
\hline $\begin{array}{l}\text { Salta, Argentina } \\
\text { (city) }\end{array}$ & 1998 & & $\begin{array}{l}\text { In } 1998 \text {, Salta granted NECON, S.A. a } 30 \text {-year, exclusive concession to } \\
\text { provide water and sewerage services. Prior to privatization, the General } \\
\text { Administration of Water of Salta (AGAS) served } 43 \text { localities, while the } \\
\text { remainder of the population (some } 25,000 \text { of a } 1997 \text { total population of } \\
1,000,983 \text { ) relied on cooperatives and other sources. }\end{array}$ \\
\hline $\begin{array}{l}\text { Santiago del Estero } \\
\text {-La Banda, } \\
\text { Argentina (cities) }\end{array}$ & 1997 & & $\begin{array}{l}\text { In 1997, the provincial government of Santiago del Estero awarded a } \\
\text { concession of water and sanitation services to Aguas de Santiago, S.A., } \\
\text { a private consortium comprised of several Argentine firms. }\end{array}$ \\
\hline $\begin{array}{l}\text { Posadas, Argentina } \\
\text { (city) }\end{array}$ & 1999 & & $\begin{array}{l}\text { In } 1999 \text {, the provincial government of Misiones awarded a } 30 \text {-year } \\
\text { concession contract for the provision of water and sanitation services to } \\
\text { Servicios de Aguas de Misiones S.A. (SAMSA). The private water } \\
\text { company belongs }(90 \%) \text { to the Spanish group Dragados. Dragados' }\end{array}$ \\
\hline
\end{tabular}

\footnotetext{
22 If cancelled during or before the last year of survey data for that country (2002 for Argentina, 2001 for Bolivia, and 2001 for Brazil)
} 


\begin{tabular}{|c|c|c|c|}
\hline $\begin{array}{l}\text { Geographical Area } \\
\text { with PSP }\end{array}$ & $\begin{array}{l}\text { Year } \\
\text { of PSP }\end{array}$ & $\begin{array}{l}\text { Year PSP } \\
\text { cancelled }^{22}\end{array}$ & Description of Private Sector Involvement \\
\hline & & & subsidiary, Urbaser S.A., provides the company's management services. \\
\hline $\begin{array}{l}\text { Corrientes, } \\
\text { Argentina (city) }\end{array}$ & 1991 & & $\begin{array}{l}\text { In 1991, the provincial government of Corrientes became the first } \\
\text { provincial government in Argentina to award a concession contract in } \\
\text { the water sector. As for most subsequent Argentine concession } \\
\text { contracts, the contract was awarded to the company that agreed to } \\
\text { charge the lowest price (i.e., bidding was over average service price). } \\
\text { The government awarded a } 30 \text {-year concession to Aguas de Corrientes, } \\
\text { S.A.- - a consortium comprised entirely of private, Argentine } \\
\text { corporations. }\end{array}$ \\
\hline $\begin{array}{l}\text { Formosa, Argentina } \\
\text { (city) }\end{array}$ & 1995 & & $\begin{array}{l}\text { In } 1995 \text {, the provincial government of Formosa awarded a concession of } \\
\text { water and sanitation services to Aguas de Formosa, a private consortium } \\
\text { of which SAGUA Internacional S.A., an Argentine corporation, owned } \\
80 \% \text {. The province retained } 10 \% \text { of the company's shares. }\end{array}$ \\
\hline $\begin{array}{l}\text { Catamarca, } \\
\text { Argentina (city) }\end{array}$ & 2000 & & $\begin{array}{l}\text { In } 2000 \text {, the provincial government of Catamarca privatized the } \\
\text { province's water and sanitation company, Obras Sanitarias de } \\
\text { Catamarca (OSCA). The government awarded a } 30 \text {-year concession } \\
\text { contract to FCC and Vivendi joint subsidiary Proactiva Medio } \\
\text { Ambiente. Proactiva won the concession after bidding to pay } 12.5 \% \text { of } \\
\text { annual billing to the provincial government. }\end{array}$ \\
\hline $\begin{array}{l}\text { Gran Mendoza, } \\
\text { Argentina (city) }\end{array}$ & 1998 & & $\begin{array}{l}\text { In 1998, the provincial government of Mendoza granted a } 25 \text {-year } \\
\text { concession to Obras Sanitarias Mendoza S.A., a private consortium } \\
\text { comprised of American, Argentina, and French corporations. The } \\
\text { province retained } 20 \% \text { of the shares in the water company. }\end{array}$ \\
\hline $\begin{array}{l}\text { La Rioja, Argentina } \\
\text { (city) }\end{array}$ & 2002 & & $\begin{array}{l}\text { In } 1999 \text {, the provincial government of La Rioja awarded a contract to } \\
\text { Latin Aguas to manage the public water and sanitation utility, Aguas de } \\
\text { la Rioja. In the first six months of the management contract, Latin } \\
\text { Aguas increased water supply from } 6 \text { to } 24 \text { hours per day, reduced } \\
\text { operating costs by } 40 \% \text {, and increased the collection rate from } 10-12 \% \\
\text { to } 80 \% \text {. In } 2002 \text {, the government awarded Latin Aguas a } 30 \text {-year } \\
\text { concession in water and sanitation. Latin Aguas also holds operating } \\
\text { concessions in the provinces of Salta and Corrientes }\end{array}$ \\
\hline $\begin{array}{l}\text { La Paz and El Alto, } \\
\text { Bolivia (cities) }\end{array}$ & 1997 & & $\begin{array}{l}\text { In } 1997 \text { the Bolivian government awarded a water and sanitation } \\
\text { concession contract to the private consortium Aguas del Illimani, led by } \\
\text { Suez Lyonnaise des Eaux. It was the first major concession contract in } \\
\text { Bolivia. In contrast to other concession contracts (e.g., the Buenos } \\
\text { Aires concession contract), bidding was conducted over coverage targets } \\
\text { rather than tariff reductions. The concessionaire committed to } \\
\text { increasing sewerage coverage to } 90 \% \text { and } 95 \% \text { in El Alto and La Paz, } \\
\text { respectively. }\end{array}$ \\
\hline $\begin{array}{l}\text { Cochabamba, } \\
\text { Bolivia (city) }\end{array}$ & 1999 & & $\begin{array}{l}\text { In 1999, the government signed a } 40 \text {-year concession contract with } \\
\text { Aguas del Tunari (AdT). Included in the contract was a guarantee to the } \\
\text { operator of profitability. Five months after the concession was granted, } \\
\text { the population rioted against water tariff increases and the contract was } \\
\text { cancelled because of pervasive civil disorder (thus returning to the } \\
\text { former, public operator, SEMAPA). }\end{array}$ \\
\hline
\end{tabular}




\begin{tabular}{|l|l|l|l|}
\hline $\begin{array}{l}\text { Geographical Area } \\
\text { with PSP }\end{array}$ & $\begin{array}{l}\text { Year } \\
\text { of PSP }\end{array}$ & $\begin{array}{l}\text { Year PSP } \\
\text { cancelled }\end{array}$ & Description of Private Sector Involvement \\
\hline $\begin{array}{l}\text { Parana, Brazil } \\
\text { (province) }\end{array}$ & 1998 & & $\begin{array}{l}\text { In 1998, the state government of Parana sold 38\% of the shares in } \\
\text { Sanepar, the public water and sanitation utility, to a private consortium } \\
\text { of which Vivendi held 30\%. The consortium power over staffing, loans, } \\
\text { deals with shareholders, and final say over tariffs. The IFC as well as } \\
\text { other international organizations provided assistance. In 2003, the state } \\
\text { governor stripped the consortium of its voting rights and announced } \\
\text { plans to reduce the consortium's stake to around 20\%. }\end{array}$ \\
$\begin{array}{l}\text { Curitiba, Brazil } \\
\text { (capital city of } \\
\text { Parana) }\end{array}$ & & \\
\hline
\end{tabular}


Table 2

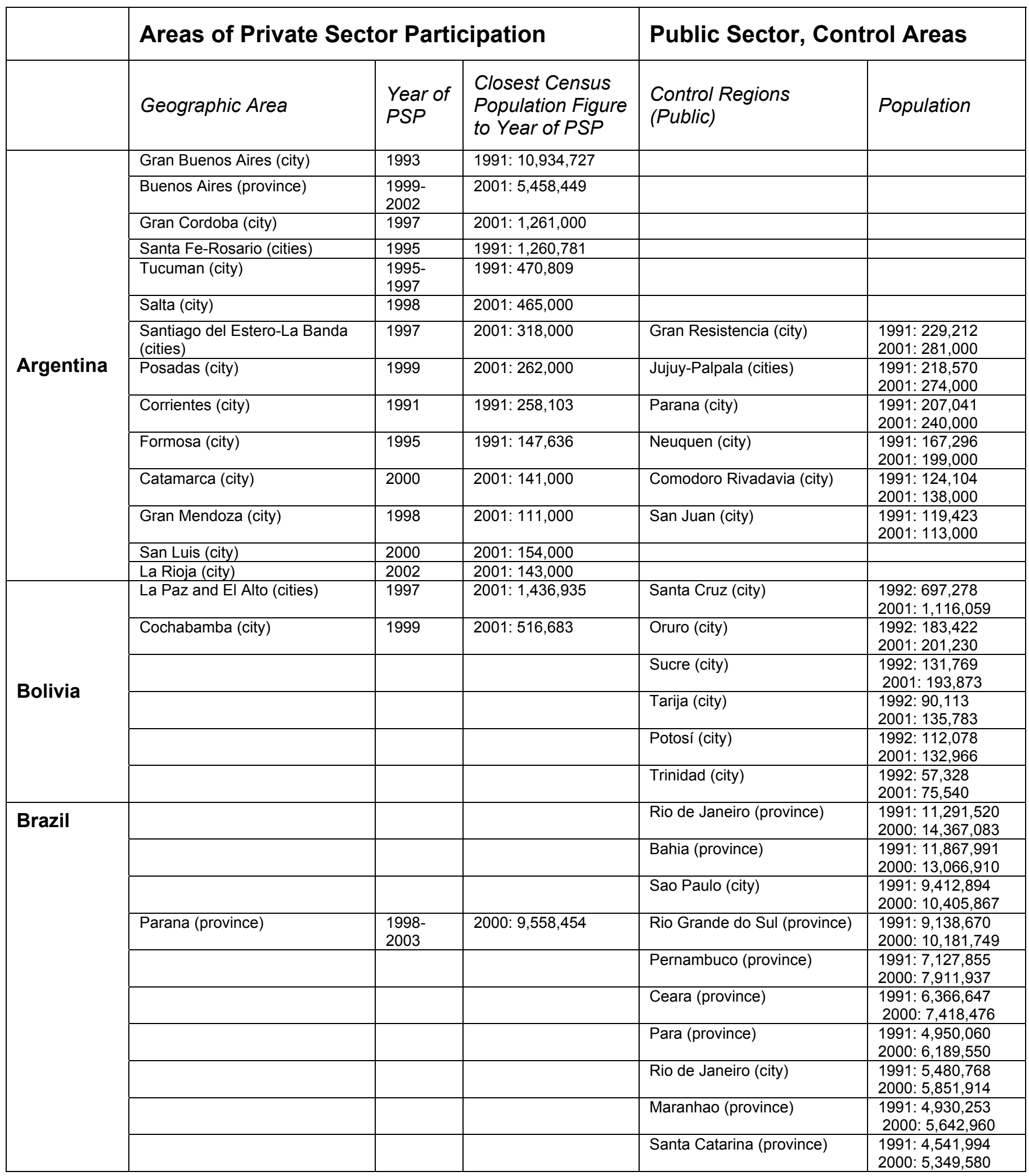




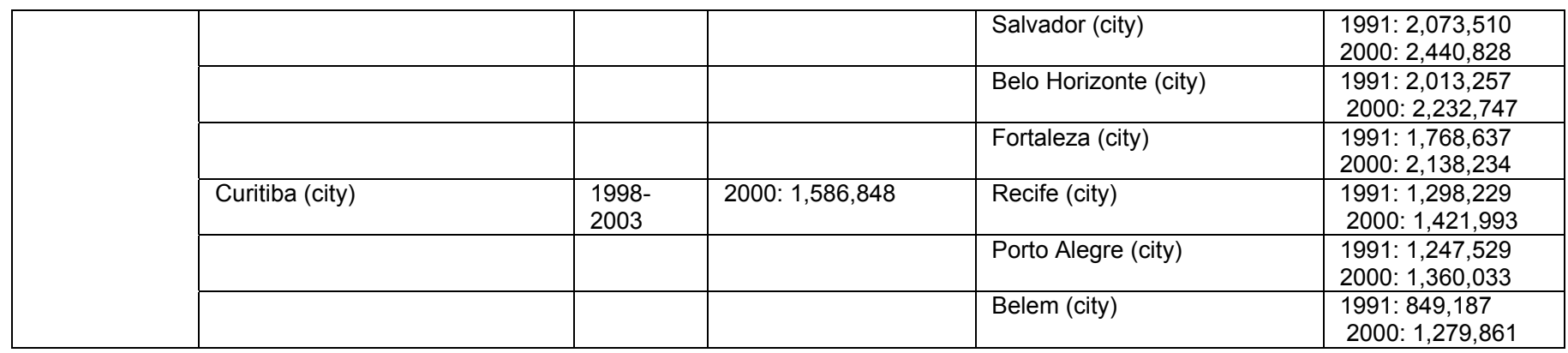

Page 29 
Table 3

\section{Piped Water and Private Participation}

\begin{tabular}{|c|c|c|c|c|}
\hline \multicolumn{5}{|c|}{$\begin{array}{l}\text { Dependent variable: share of urban households with } \\
\text { piped water connections }\end{array}$} \\
\hline Constant & $\begin{array}{c}86.663 \\
(46.70)^{* * *}\end{array}$ & $\begin{array}{c}88.532 \\
(29.49)^{* * *}\end{array}$ & $\begin{array}{c}92.875 \\
(23.52)^{* * *}\end{array}$ & $\begin{array}{c}94.442 \\
(25.12)^{\star * *}\end{array}$ \\
\hline private & $\begin{array}{c}2.970 \\
(1.98)^{\star *}\end{array}$ & $\begin{array}{l}1.117 \\
(0.72)\end{array}$ & $\begin{array}{r}-2.225 \\
(0.88)\end{array}$ & \\
\hline concession & & & & $\begin{array}{r}-2.333 \\
(0.92)\end{array}$ \\
\hline joint ownership & & & & $\begin{array}{l}1.618 \\
(0.25)\end{array}$ \\
\hline control (always public) & & & $\begin{array}{l}-4.004 \\
(1.68)^{*}\end{array}$ & $\begin{array}{l}-3.917 \\
(1.64)\end{array}$ \\
\hline city/region population & $\begin{array}{l}-0.424 \\
(2.08)^{\star \star}\end{array}$ & $\begin{array}{l}-0.324 \\
(1.59)\end{array}$ & $\begin{array}{l}-0.280 \\
(1.37)\end{array}$ & $\begin{array}{l}-0.293 \\
(1.42)\end{array}$ \\
\hline $\begin{array}{l}\text { gdp per capita } \\
\text { year dummies }\end{array}$ & $\begin{array}{c}1.217 \\
(4.02)^{\star * *}\end{array}$ & $\begin{array}{c}1.142 \\
(3.72)^{* * *} \\
\text { yes }\end{array}$ & $\begin{array}{c}1.013 \\
(3.22)^{\star * *} \\
\text { yes }\end{array}$ & $\begin{array}{c}1.032 \\
(3.26)^{\star * *} \\
\text { yes }\end{array}$ \\
\hline Obse & 158 & 158 & 158 & 15 \\
\hline R-squared & 0.19 & 0.27 & 0.28 & 0.28 \\
\hline
\end{tabular}

Absolute value of $\mathrm{t}$ statistics in parentheses

* significant at $10 \%$; ${ }^{* *}$ significant at $5 \%$; ${ }^{* * *}$ significant at $1 \%$ 


\begin{tabular}{|c|c|c|c|c|}
\hline \multicolumn{5}{|c|}{ Sewerage and Private Participation } \\
\hline \multicolumn{5}{|c|}{$\begin{array}{c}\text { Dependent variable: share of urban households with } \\
\text { inside flush toilets }\end{array}$} \\
\hline Constant & $\begin{array}{c}62.959 \\
(13.64)^{* * *}\end{array}$ & $\begin{array}{c}71.684 \\
(8.63)^{\star * *}\end{array}$ & $\begin{array}{c}79.315 \\
(7.02)^{\star * *}\end{array}$ & $\begin{array}{c}79.210 \\
(6.98)^{\star * *}\end{array}$ \\
\hline private & $\begin{array}{c}8.316 \\
(2.06)^{* *}\end{array}$ & $\begin{array}{l}5.723 \\
(1.35)\end{array}$ & $\begin{array}{r}-1.092 \\
(0.14)\end{array}$ & \\
\hline concession & & & & $\begin{array}{r}-1.254 \\
(0.15)\end{array}$ \\
\hline joint ownership & & & & $\begin{array}{l}3.328 \\
(0.19)\end{array}$ \\
\hline control (always public) & & & $\begin{array}{l}-7.645 \\
(1.00)\end{array}$ & $\begin{array}{r}-7.554 \\
(0.98)\end{array}$ \\
\hline city/region population & $\begin{array}{l}-1.724 \\
(3.28)^{\star \star *}\end{array}$ & $\begin{array}{l}-1.403 \\
(2.53)^{* *}\end{array}$ & $\begin{array}{l}-1.349 \\
(2.42)^{* *}\end{array}$ & $\begin{array}{l}-1.366 \\
(2.43)^{\star *}\end{array}$ \\
\hline $\begin{array}{l}\text { gdp per capita } \\
\text { year dummies }\end{array}$ & $\begin{array}{l}0.586 \\
(0.74)\end{array}$ & $\begin{array}{c}-0.150 \\
(0.17) \\
\text { yes }\end{array}$ & $\begin{array}{c}-0.272 \\
(0.30) \\
\text { yes }\end{array}$ & $\begin{array}{c}-0.246 \\
(0.27) \\
\text { yes }\end{array}$ \\
\hline $\begin{array}{l}\text { Observations } \\
\text { R-squared }\end{array}$ & $\begin{array}{l}140 \\
0.13\end{array}$ & $\begin{array}{l}140 \\
0.16\end{array}$ & $\begin{array}{l}140 \\
0.17\end{array}$ & $\begin{array}{l}140 \\
0.17\end{array}$ \\
\hline $\begin{array}{l}\text { Absolute value of } t \text { stat } \\
{ }^{*} \text { significant at } 10 \% ;{ }^{* *}\end{array}$ & $\begin{array}{l}\text { stics in pare } \\
\text { ignificant at }\end{array}$ & $\begin{array}{l}\text { ntheses } \\
5 \% ;{ }^{* * *} \mathrm{~s}\end{array}$ & cant a & \\
\hline
\end{tabular}




\section{APPENDICES}

Table A1: Effect of Reforms Involving Private Sector Participation on Sector Performance, Qualitative Assessments in Case Studies.

\begin{tabular}{|c|c|c|c|c|c|}
\hline $\begin{array}{l}\text { Country } \\
\text { (City) }\end{array}$ & Year & $\begin{array}{c}\text { Case studies } \\
\text { include } \\
\text { information } \\
\text { until: } \\
\end{array}$ & $\begin{array}{l}\text { Type of } \\
\text { Contract }\end{array}$ & Assessment & Case Studies \\
\hline \multicolumn{6}{|l|}{ Africa } \\
\hline $\begin{array}{l}\text { Côte d'Ivoire } \\
\text { (All) }\end{array}$ & $1988^{\mathrm{a}}$ & 2000 & Lease & $\begin{array}{l}\text { Positive } \\
\text { In contrast to water utilities elsewhere in Africa, the private sector has played a } \\
\text { significant role in the water sector in Côte d'Ivoire for over } 40 \text { years. However, the role } \\
\text { of the private operator has changed several times over this period. The most recent } \\
\text { significant reform was in 1987, when the private operator gained greater control over } \\
\text { investment resources, which were funded through a surtax on water sales, and was } \\
\text { forced to assume greater commercial risk (i.e., contract provisions that compensated the } \\
\text { operator if actual revenue fell short of projected revenue were eliminated). } \\
\text { Overall, most assessments of the reform were positive. In particular, after stagnating for } \\
\text { several years before the reform was initiated, the number of connections increased } \\
\text { significantly after the private operator assumed greater control over investment } \\
\text { resources. Furthermore, the operator continued to improve upon its already strong } \\
\text { commercial and technical performance and prices slowly fell in real terms. Despite the } \\
\text { generally positive assessment of the reform, some observers have noted that some } \\
\text { problems remain. In particular, the private operator's financial performance deteriorated } \\
\text { following the recent political problems in Côte d'Ivoire. The economic problems that } \\
\text { have resulted from the political events have contributed to a slowdown in investment } \\
\text { and reduction in collection rates from both private and public customers. The slowdown } \\
\text { has also meant that the government has refused to implement agreed tariff increases and, } \\
\text { consequently, tariffs have continued to fall in real terms. }\end{array}$ & $\begin{array}{l}\text { Collignon (2002) } \\
\text { Kerf (2000) } \\
\text { Menard and Clarke (2002a) } \\
\text { Trémolet, Browning and Howard } \\
(2002)\end{array}$ \\
\hline Gabon (All) & 1997 & 2000 & $\begin{array}{l}\text { Concession } \\
(20 \text { year })\end{array}$ & $\begin{array}{l}\text { Positive } \\
\text { In 1997, Gabon awarded the first true concession in the water sector in Africa to a } \\
\text { private sector operator., who assumed responsibility for water and electricity in the } \\
\text { country. Tremolet and Neale (2002) report that the private operator improved service } \\
\text { quality and coverage, while reducing tariffs - a } 17.25 \text { percent price reduction was } \\
\text { enacted when the concession was implement. The private operator made almost } 40 \\
\text { percent of the investment required under the } 20 \text {-year contract in the first five years, } \\
\text { outperforming its contractual coverage targets in most areas. Trémolet (2002) notes that } \\
\text { the rapid expansion of water coverage was in part due to cross-subsidization from the } \\
\text { electricity sector. Further, they note that delays in meeting the remaining targets were } \\
\text { mainly due to delays in the government delivering on its planned investments. They } \\
\text { also note that the operator's commercial performance was generally strong and that its } \\
\text { financial performance had improved, reducing the cash flow problems that had been one } \\
\text { of the motivations for reform. However, they noted that the regulatory and monitoring } \\
\text { tools needed to assess the overall performance of the company had not been put in place } \\
\text { by } 2002 \text {, especially outside of the main cities. }\end{array}$ & $\begin{array}{l}\text { Trémolet (2002) } \\
\text { Trémolet and Neale (2002) }\end{array}$ \\
\hline
\end{tabular}




\begin{tabular}{|c|c|c|c|c|c|}
\hline $\begin{array}{l}\text { Country } \\
\text { (City) }\end{array}$ & Year & $\begin{array}{c}\text { Case studies } \\
\text { include } \\
\text { information } \\
\text { until: }\end{array}$ & $\begin{array}{c}\text { Type of } \\
\text { Contract }\end{array}$ & Assessment & Case Studies \\
\hline Gambia (All) & 1993 & 1995 & Lease & $\begin{array}{l}\text { Negative. Cancelled after implementation. } \\
\text { After several failed attempts aimed at improving the performance of a publicly owned } \\
\text { utility in Gambia, the government signed a lease contract with a private sector company, } \\
\text { Management Services Gambia (MSG) that was mainly owned by SOGEA, a subsidiary } \\
\text { of the French company Générale des Eaux (now Vivendi). The private operator took } \\
\text { control of the utility in July 1993. At the same time, a public enterprise was set up to } \\
\text { retain ownership of sector assets. Although there were some improvements in } \\
\text { performance following the introduction of private sector participation - most notably } \\
\text { total production appears to have increased over the period of the lease, the number of } \\
\text { connections improved and it appeared that system renewals completed during the period } \\
\text { of the lease might have reduced unaccounted for water, these improvements were } \\
\text { attributed to the World Bank supported Water Supply and Electricity Project rather than } \\
\text { the lease contract per se (see, e.g., Kerf, 2000, p. 21). } \\
\text { In February 1995, less than a year and a half after the private operator took control, the } \\
\text { government unilaterally revoked the contract. This decision appears to have been due to } \\
\text { political change following a } 1994 \text { coup, poor relations between the state company that } \\
\text { controlled sector assets and the private company in charge of operations and } \\
\text { maintenance, disagreements between the government and the private operator over } \\
\text { contract provisions, and public discontent with private operations, in part due to the } \\
\text { private operators campaign to disconnect non-payers (Kerf, 2000). }\end{array}$ & Kerf (2000) \\
\hline Guinea (All) & 1989 & 1999 & $\begin{array}{l}\text { Lease } \\
\text { (10 year) }\end{array}$ & $\begin{array}{l}\text { Mixed, but mostly positive } \\
\text { In general, most performance indicators improved following the introduction of private } \\
\text { sector participation. The number of connections increased significantly in Conakry and } \\
\text { in the rest of the country. Furthermore, the private operators commercial and technical } \\
\text { performance was significantly stronger than the performance under public ownership - } \\
\text { labor and total factor productivity improved significantly following the reform, the } \\
\text { private operator rapidly metered households, businesses and government agencies, bill } \\
\text { collection from private consumers improved and service and water quality improved } \\
\text { significantly. In a detailed cost-benefit analysis, Clarke, Ménard and Zuluaga (2002) } \\
\text { concluded that the total benefits of reform exceeded } \$ 33 \text { million (in } 1996 \text { US\$) between } \\
1989 \text { and } 1999 \text {. } \\
\text { However, it is important to note that the gains were achieved relative to the very weak } \\
\text { initial conditions and that problems remained throughout the reform period. In } \\
\text { particular, prices increased significantly (over } 400 \% \text { in real terms) making piped water } \\
\text { unaffordable for many low-income consumers. The high price of water, in turn, meant } \\
\text { that the number of connections remained very low even by regional standards. } \\
\text { Furthermore, the reform ultimately proved unsustainable. After the lease expired in } \\
1999 \text {, it was not renewed and the international enterprise withdrew from the country in } \\
2001 \text {. }\end{array}$ & $\begin{array}{l}\text { Book Cowen (1999) } \\
\text { Brook and Lucussol (2001) } \\
\text { Clarke, Ménard and Zuluaga (2002) } \\
\text { Kerf (2000) } \\
\text { Ménard and Clarke (2002b) } \\
\text { Rivera (1996) }\end{array}$ \\
\hline
\end{tabular}

Page 33 


\begin{tabular}{|c|c|c|c|c|c|}
\hline $\begin{array}{l}\text { Country } \\
\text { (City) }\end{array}$ & Year & $\begin{array}{c}\text { Case studies } \\
\text { include } \\
\text { information } \\
\text { until: } \\
\end{array}$ & $\begin{array}{c}\text { Type of } \\
\text { Contract }\end{array}$ & 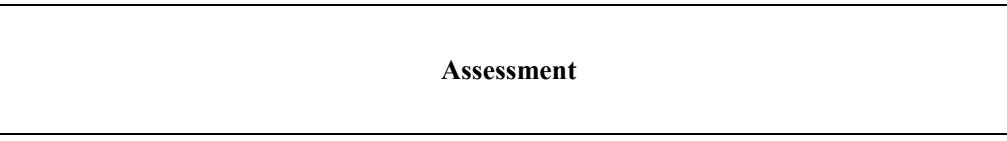 & Case Studies \\
\hline Senegal (All) & 1996 & 2000 & Lease & $\begin{array}{l}\text { Positive } \\
\text { Although progress on some performance indicators (e.g., unaccounted-for-water and } \\
\text { progress with some contractual works) has been more modest than was originally hoped } \\
\text { for, most performance indicators improved following the introduction of private sector } \\
\text { participation. In particular, the number of connections increased quite significantly over } \\
\text { the first five years of the contract - from about } 204,000 \text { in } 1995 \text { to close to } 300,000 \text { by } \\
2001 \text { - and productive capacity improved modestly. Furthermore, the operator managed } \\
\text { to improve performance along several other dimensions. For example, it increased } \\
\text { billing efficiency, reduced unaccounted for water, improved water quality and reduced } \\
\text { number of employees. Finally, despite the modest price increases, low-income } \\
\text { consumers appear to have benefited from reform. In particular, Clarke and Wallsten } \\
\text { (2002) note that the connection rate increased more quickly for households in Dakar } \\
\text { headed by individuals with no formal education than it increased for other households. }\end{array}$ & $\begin{array}{l}\text { Kerf }(2000) \\
\text { Trémolet, Browning and Howard } \\
(2002) \\
\text { World Bank (2001) }\end{array}$ \\
\hline $\begin{array}{l}\text { South Africa } \\
\text { (Queenstown) }\end{array}$ & 1992 & 2000 & $\begin{array}{l}\text { Concession } \\
(25 \text { Years }\end{array}$ & $\begin{array}{l}\text { Mixed (Modest Improvements) } \\
\text { Description: Concession Contract ( } 25 \text { years). In 1992, the municipality of Queenstown } \\
\text { entered into a concession contract with Water Services of South Africa (WSSA - lead } \\
\text { investor: Suez Lyonnaise). The contract was for } 15 \text { years (later extended to 25). The } \\
\text { company was responsible for operations, maintenance and management of the systems. } \\
\text { However, billing and the collection remained the responsibilities of the municipality, as } \\
\text { the legal system did not allow private sector involvement in these activities. In 1995, } \\
\text { when municipal boundaries changed to incorporate two new areas (Mlungisi and } \\
\text { Ezibeleni), the contract was extended to cover the } 170,000 \text { new inhabitants- up from } \\
\text { only } 22,000 \text { in } 1992 \text {. } \\
\text { Outcome: Coverage was already universal when the contract was signed and, therefore, } \\
\text { there was little expansion (other than to new low-income housing). Due to contract } \\
\text { restrictions, there were no layoffs. Consequently, connections per worker did not } \\
\text { improve. However, there were some quality improvements: unaccounted for water fell } \\
\text { from } 45 \% \text { to } 21 \% \text { by 2000, pipe bursts became less common and } 65 \% \text { of ageing water } \\
\text { pipes in Mlungisi and Ezibelenii. However, water bills increased for low-income } \\
\text { consumers and nonpayment remains a problem in Mlungisi (55\% in Jan 2000) and } \\
\text { Ezibeleni (56\% in Jan 2000). }\end{array}$ & Palmer Development Group (2000) \\
\hline \multicolumn{6}{|c|}{ (1) } \\
\hline China (Macau) & 1985 & 1998 & $\begin{array}{l}\text { Concession } \\
\text { (25 Years) }\end{array}$ & & Porter (2001) \\
\hline
\end{tabular}




\begin{tabular}{|c|c|c|c|c|c|}
\hline $\begin{array}{l}\text { Country } \\
\text { (City) }\end{array}$ & Year & $\begin{array}{l}\text { Case studies } \\
\text { include } \\
\text { information } \\
\text { until: }\end{array}$ & $\begin{array}{c}\text { Type of } \\
\text { Contract }\end{array}$ & Assessment & Case Studies \\
\hline India (Pune) & 1998 & 2000 & $\begin{array}{l}\text { Management } \\
\text { Contract }\end{array}$ & $\begin{array}{l}\text { Negative. Cancelled before implementation } \\
\text { In 1998, the municipal government attempted to solicit bids for a contract that was } \\
\text { intended to increase sector coverage and improve sector performance. The contract } \\
\text { contained three components: a fixed-price, fixed-time ( } 36 \text { month) construction contract } \\
\text { that would extend and improve the water and sewerage networks, improve existing } \\
\text { sewage treatment plants and construct a new water treatment plant; a five-year } \\
\text { operations and maintenance contract; and a five-year contract designed to improve } \\
\text { billing and collection. The project would have resulted in substantial tariff increases } \\
\text { ( } 25 \% \text { for water charges for domestic users and } 43 \% \text { for standpipe charges). After } \\
\text { companies had been pre-qualified and had submitted bids, the municipal government } \\
\text { cancelled the project a few weeks before the contract was going to be awarded. Zérah } \\
\text { (2000) argues that the cancellation was increase in opposition following local elections, } \\
\text { the transfer of a district commissioner who had championed the reform, and growing } \\
\text { concern about the cost of the project and the rate of return than private operators might } \\
\text { get from the project especially after tariffs had been increased during project } \\
\text { preparation. }\end{array}$ & Zérah (2000) \\
\hline \multicolumn{6}{|l|}{$\begin{array}{l}\text { Malaysia } \\
\text { (Johor Bahru) }\end{array}$} \\
\hline $\begin{array}{l}\text { Philippines } \\
\text { (Manila) }\end{array}$ & 1997 & 2003 & $\begin{array}{l}\text { Two } \\
\text { Concessions } \\
\text { (Both for } 25 \\
\text { years) }\end{array}$ & $\begin{array}{l}\text { Mixed. One concession cancelled after implementation } \\
\text { In response to a water crisis characterized by low coverage, unsustainably high UFW, } \\
\text { poor management, and inadequate investment, Filipino authorities brokered the } \\
\text { privatization of Manila's Metropolitan Waterworks and Sewerage System (MWSS) in } \\
\text { 1997. Although it would become the largest water concession in the world, feasibility } \\
\text { studies recommended full, not partial, privatization. The government divided the total } \\
\text { service area into two zones and granted the Eastern zone to an Ayala/Bechtel consortium } \\
\text { named Maynilad Water Services, Inc. (MWSI) and the Western zone to a Benpres } \\
\text { Holdings/Suez consortium named the Manila Water Company (MWC). Each } \\
\text { concession was granted for a period of } 25 \text { years, and MWSS became the sector } \\
\text { regulator. Included in the contracts was a JV agreement for common facilities and an } \\
\text { interconnection agreement. } \\
\text { In 1998, both corporations sought tariff increases despite a five-year freeze on prices } \\
\text { laid out in each contract. Although the contracts provided for "Extraordinary Price } \\
\text { Adjustments" if the circumstances merited it, these tariff adjustments were to be spread } \\
\text { over the length of the concession. In response to the peso devaluation that resulted from } \\
\text { the regional crisis of } 1997 \text {, a } 30 \% \text { drop in water supply owing to El Niño effects, and } \\
\text { unforeseen increases in capital costs, MWSI requested a sharp increase in tariffs in the } \\
\text { first review rather than a gradual rise. Although MWSS did increase tariffs, it did not } \\
\text { approve the particular increases requested by MWSI. While the Manila concession } \\
\text { improved service coverage and quality along many lines, MWSI never operated } \\
\text { profitably, and the firm unilaterally terminated its contract in December of } 2002 \text {. MWSI } \\
\text { claims that MWSS violated the terms of its contract and seeks the return of US\$303 } \\
\text { million in investment. }\end{array}$ & $\begin{array}{l}\text { Dumol (2000) } \\
\text { Santos (2003) } \\
\text { Porter (2001) }\end{array}$ \\
\hline
\end{tabular}

Page 35 


\begin{tabular}{|c|c|c|c|c|c|}
\hline $\begin{array}{l}\text { Country } \\
\text { (City) }\end{array}$ & Year & $\begin{array}{c}\text { Case studies } \\
\text { include } \\
\text { information } \\
\text { until: }\end{array}$ & $\begin{array}{c}\text { Type of } \\
\text { Contract }\end{array}$ & Assessment & Case Studies \\
\hline $\begin{array}{l}\text { Poland } \\
\text { (Gdansk) }\end{array}$ & 1992 & 1996 & $\begin{array}{l}\text { Lease ( } 30 \\
\text { Years) }\end{array}$ & $\begin{array}{l}\text { Positive, despite initial complications } \\
\text { In the early 1990s, the process of democratization, decentralization, and market reform } \\
\text { in Poland shifted many responsibilities from the central government to the } \\
\text { municipalities. One of these reforms included the introduction of private sector } \\
\text { participation in the water and sanitation sector in Gdansk. In 1991, the municipal } \\
\text { council of Gdansk liquidated the regional water utility and began negotiations with a } \\
\text { French company, Saur, regarding the management and operation of the system. In 1992, } \\
\text { the city of Gdansk and Saur created a mixed company, Saur Neptun Gdansk S.A. } \\
\text { (SNG), with } 49 \% \text { owned by the city and 51\% owned by Saur. In 1993, the city of } \\
\text { Gdansk and SNG signed a } 30 \text {-year lease contract. The city maintained ownership of the } \\
\text { assets, responsibility for investment and tariff-setting, and regulatory duties. The private } \\
\text { operator took over operation, maintenance, billing and collection. } \\
\\
\text { Before private sector involvement, the water and sanitation system of Gdansk had } \\
\text { numerous deficiencies and was generally in need of more efficient management and } \\
\text { network expansion. Although Rivera (1996) describes a complex and tense relationship } \\
\text { between the city and SNG, which led to contract renegotiation in 1995, the lease has had } \\
\text { generally positive effects. Most notably, the private operator raised the quality of } \\
\text { drinking water to EU standards after a single year, improved collections rates, decreased } \\
\text { operating costs, and constructed a modern laboratory for the effective control of } \\
\text { drinking water quality and effluents. Nonetheless, Rivera (1996) notes that the contract } \\
\text { did not establish a systemic tariff-setting mechanism, and that tariff increases had an } \\
\text { "unforeseen" negative impact on water consumption levels. }\end{array}$ & Rivera (1996) \\
\hline
\end{tabular}

Page 36 


\begin{tabular}{|c|c|c|c|c|c|}
\hline $\begin{array}{l}\text { Country } \\
\text { (City) }\end{array}$ & Year & $\begin{array}{c}\text { Case studies } \\
\text { include } \\
\text { information } \\
\text { until: }\end{array}$ & $\begin{array}{c}\text { Type of } \\
\text { Contract }\end{array}$ & Assessment & Case Studies \\
\hline \multicolumn{6}{|c|}{ Latin America } \\
\hline $\begin{array}{l}\text { Argentina } \\
\text { (Buenos } \\
\text { Aires) }\end{array}$ & 1993 & 1998 & $\begin{array}{c}\text { Concession } \\
(30 \text { year })\end{array}$ & $\begin{array}{l}\text { Positive } \\
\text { Most of the case studies looking at the Buenos Aires concession agree that it was } \\
\text { successful along many dimensions. The contract was bid based upon the price reduction } \\
\text { that the winning bidder would implement, resulting in a } 27 \text { percent price decrease. In } \\
\text { addition, investment increased following the introduction of private sector participation, } \\
\text { operating efficiency improved, access increased significantly and water and service } \\
\text { quality improved. In a detailed cost-benefit analysis, Alcazar et al. (2002) estimated that } \\
\text { the total welfare gains during the first ten years of the contract would exceed } \$ 1.6 \\
\text { billion. } \\
\text { However, there were some notable problems. One problem was that the concession } \\
\text { contract preserved a complicated, non-transparent pricing scheme that depended on } \\
\text { several criteria including the zone where the property is located, the quality of the } \\
\text { residence and the size of the property. According to Artana et al. (1999) this meant that } \\
\text { the concessionaire expended considerable effort trying to reassess properties. Second, } \\
\text { the renegotiations that occurred after the privatization took place led to questions about } \\
\text { whether the concessionaire had deliberately bid a price that was too low to assure } \\
\text { sustainability, banking on having the option to renegotiate the contract at a later date. } \\
\text { For example, Abdala (1997) noted that the concessionaire would have been able to meet } \\
\text { contractual obligations regarding its debt to net worth ratio only if either prices were } \\
\text { increased or it was freed from its investment obligations. Subsequent renegotiations in } \\
1994 \text { and } 1998 \text { that resulted in price increases resulted in public dissatisfaction. Finally, } \\
\text { the regulator was not independent from political pressure, leading to concerns about } \\
\text { politically motivated interventions. As in the other Argentine cases, the case studies } \\
\text { were completed prior to the recent economic crisis meaning that they do not address } \\
\text { concerns about the medium-term sustainability of reform. }\end{array}$ & $\begin{array}{l}\text { Abdala (1997) } \\
\text { Alcázar, Abdala and Shirley (2002) } \\
\text { Artana, Navajas and Urbiztondo (1999) } \\
\text { Crampes and Estache (1996) } \\
\text { Rivera (1996) }\end{array}$ \\
\hline
\end{tabular}

Page 37 


\begin{tabular}{|c|c|c|c|c|c|}
\hline $\begin{array}{l}\text { Country } \\
\text { (City) }\end{array}$ & Year & $\begin{array}{l}\text { Case studies } \\
\text { include } \\
\text { information } \\
\text { until: }\end{array}$ & $\begin{array}{c}\text { Type of } \\
\text { Contract }\end{array}$ & Assessment & Case Studies \\
\hline $\begin{array}{l}\text { Argentina } \\
\text { (Cordoba) }\end{array}$ & 1997 & 1999 & $\begin{array}{r}\text { Concession } \\
(30 \text {-year })\end{array}$ & $\begin{array}{l}\text { Positive } \\
\text { In } 1997 \text {, the provincial government of Cordoba signed a } 30 \text {-year connection contract } \\
\text { with Aguas Cordobesas, a private company owned by Suez-Lyonnaise des Eaux and } \\
\text { domestic investors. Nickson (2001) reports that the reform was generally seen } \\
\text { positively by most consumers and by the provincial government. In particular, he notes } \\
\text { that consumers benefited from reduced tariffs, improved water quality, which resulted in } \\
\text { reduced sales of bottled water, improved service quality and reduced service cutoffs, and } \\
\text { a } \$ 13 \text { million royalty payment that was received by the provincial government. He also } \\
\text { notes that the company expanded service and improved productivity. } \\
\text { However, he does note that there were some potential problems even in the early years. } \\
\text { In particular, he noted that there was some concern about public dissatisfaction due to } \\
\text { supply being cutoff to households that do not pay their water bills and that there is a } \\
\text { concern that the investment target, which requires that the company achieves } 97 \% \\
\text { coverage by } 2026 \text { but has no interim coverage goals, might result in the concessionaire } \\
\text { back-loading investment to the end of the contract. An additional problem, which is not } \\
\text { discussed in Nickson (2001), is the potential disruption due to the devaluation of the } \\
\text { peso and the ensuing economic crisis in Argentina at the end of } 2001 \text {. Until the crisis is } \\
\text { fully resolved, public dissatisfaction with liberalization in general and private sector } \\
\text { participation in infrastructure in particular could lead to contractual disputes that might, } \\
\text { in the medium term, threaten many sector reforms.. }\end{array}$ & Nickson (2001a) \\
\hline $\begin{array}{l}\text { Argentina } \\
\text { (Corrientes) }\end{array}$ & 1991 & 1996 & $\begin{array}{c}\text { Concession } \\
(30 \text {-year) }\end{array}$ & $\begin{array}{l}\text { Positive } \\
\text { The provincial government of Corrientes was the first provincial government in } \\
\text { Argentina to award a concession contract in the water sector. As for most subsequent } \\
\text { Argentine concession contracts, the contract was awarded to the company that agreed to } \\
\text { charge the lowest price (i.e., bidding was over average service price). Most performance } \\
\text { indicators appeared to improve following the reform. Coverage increased for both water } \\
\text { and sewerage services, slightly surpassing contractual obligations by early } 1996 \text {. } \\
\text { Furthermore, the operator increased metering, resulting in a reduction in water } \\
\text { consumption, reduced unaccounted for water and improved productivity. Artana et al. } \\
\text { (1999), however, note some problems with the contract. Most notably, they note that the } \\
\text { regulator is not independent from legislative interference, making it possible for the } \\
\text { provincial government to harass the private operator. As in the other Argentine cases, } \\
\text { the case studies were completed prior to the recent economic crisis and, therefore, } \\
\text { questions about the long-term sustainability of the reforms remain. }\end{array}$ & Artana, Navajas and Urbiztondo (1999) \\
\hline
\end{tabular}

Page 38 


\begin{tabular}{|c|c|c|c|c|c|}
\hline $\begin{array}{l}\text { Country } \\
\text { (City) }\end{array}$ & Year & $\begin{array}{c}\text { Case studies } \\
\text { include } \\
\text { information } \\
\text { until: }\end{array}$ & $\begin{array}{c}\text { Type of } \\
\text { Contract }\end{array}$ & Assessment & Case Studies \\
\hline $\begin{array}{l}\text { Argentina } \\
\text { (Salta) }\end{array}$ & 1998 & 2002 & $\begin{array}{c}\text { Concession } \\
\text { (30 years) }\end{array}$ & $\begin{array}{l}\text { Positive } \\
\text { In 1998, Salta granted NECON, S.A. an exclusive concession to provide water and } \\
\text { sewerage services. Prior to privatization, the General Administration of Water of Salta } \\
\text { (AGAS) served } 43 \text { localities, while the remainder of the population (some } 25,000 \text { of a } \\
1997 \text { total population of } 1,000,983 \text { ) relied on cooperatives and other sources. Among } \\
\text { areas serviced by AGAS in 1997, coverage rates were } 76 \% \text { for potable water and } 68 \% \\
\text { for sewerage AGAS's infrastructure and equipment suffered from a lack of investment } \\
\text { in renovation, maintenance, and service expansion. NECON's concession stipulated } \\
\text { that it could not restrict coverage to urban areas and had to grant all municipalities in } \\
\text { Salta access to basic infrastructure. It also established universal service as a primary } \\
\text { objective, placing more importance on water access than on sewerage. The concession } \\
\text { set tariffs according to the costs of providing service, and attempted to promote } \\
\text { universal access through direct subsidies from the provincial government. } \\
\\
\text { Despite minor contractual discrepancies, the privatization has been largely successful: } \\
\text { By July } 2002 \text {, coverage increased to } 95 \% \text {; quality improved to the point that } 99 \% \text { of } \\
\text { water samples met physical, chemical, and bacterial standards compared to only } 75 \% \\
\text { before privatization; service interruptions affected only } 8 \% \text { of the population served, } \\
\text { down from } 32 \% \text {; and the billing system was modernized. Tariffs increased by an } \\
\text { average of } 14 \% \text {. While the operator has been slow to incorporate localities not } \\
\text { previously served by AGAS, surveys report that consumers and provincial and } \\
\text { municipal authorities view the concession positively. Saltiel (2003) credits continuous } \\
\text { actions by governmental authorities and the firm to stimulate an atmosphere of } \\
\text { cooperation for the social acceptance of the privatization. }\end{array}$ & Salatiel (2003) \\
\hline $\begin{array}{l}\text { Argentina } \\
\text { (Tucumán) }\end{array}$ & 1995 & 2002 & $\begin{array}{c}\text { Concession } \\
\text { (30-Year) }\end{array}$ & $\begin{array}{l}\text { Negative. Cancelled after Implementation } \\
\text { In 1995, Aguas del Aconquija SA (CAA), a subsidiary of Vivendi, was granted a 30- } \\
\text { year concession to supply the province of Tucumán. The privatization contract was } \\
\text { awarded through competitive bidding to the company that agreed to allow the largest } \\
\text { price reductions, subject to management and investment requirements set by the } \\
\text { provincial government. } \\
\text { Problems quickly developed, however, and in 1997, the contract was rescinded. The } \\
\text { problems started when the concessionaire increased prices, two months after assuming } \\
\text { responsibility for operations. The average increase in consumers' water bills was } 107 \% \text {. } \\
\text { Because of tariff rebalancing, some bills rose as much as } 300 \% \text { (particularly among the } \\
\text { middle and upper class consumers). This, in turn, resulted in } 80 \% \text { of the utility's } \\
\text { customers refusing to pay their bills. In response to the losses of roughly } \$ 1.5 \text { million } \\
\text { per month that resulted from this, CAA suspended its investment program. Eventually, } \\
\text { finding requests for government intervention ineffective, Vivendi unilaterally rescinded } \\
\text { its contract and the operations were returned to public control. Vivendi filed a } \$ 100 \\
\text { million suit against the government, but an ICSID arbitration panel ruled in favor of the } \\
\text { province. }\end{array}$ & $\begin{array}{l}\text { Rais, Esquivel and Sour (2002) } \\
\text { Artana, Navajas and Urbiztondo (1998) }\end{array}$ \\
\hline
\end{tabular}

Page 39 


\begin{tabular}{|c|c|c|c|c|c|}
\hline $\begin{array}{l}\text { Country } \\
\text { (City) }\end{array}$ & Year & $\begin{array}{c}\text { Case studies } \\
\text { include } \\
\text { information } \\
\text { until: }\end{array}$ & $\begin{array}{c}\text { Type of } \\
\text { Contract }\end{array}$ & Assessment & Case Studies \\
\hline $\begin{array}{l}\text { Bolivia } \\
\text { (La Paz - El } \\
\text { Alto) }\end{array}$ & 1997 & 1999 & Concession & $\begin{array}{l}\text { Positive } \\
\text { In 1997, the first major concession contract in Bolivia, in La Paz-El Alto concession, } \\
\text { was awarded to a consortium, Aguas del Illimani, led by Suez Lyonnaise des Eaux. In } \\
\text { contrast to other concession contracts (e.g., the Buenos Aires concession contract), } \\
\text { bidding was conducted over coverage targets rather than tariff reductions. The winning } \\
\text { bidder committed to installing } 71,752 \text { new water connections in the El Alto system (the } \\
\text { poorer region) by December } 2001 \text {. This would raise coverage in this area to } 100 \\
\text { percent. In addition, the concessionaire committed to increasing sewerage coverage to } \\
90 \text { and } 95 \text { percent in El Alto and La Paz respectively. The new connections had to be } \\
\text { in-house connections. However, the Superintendent did allow the concessionaire some } \\
\text { flexibility. In particular, some of the new connections were allowed to be lower cost } \\
\text { condominial connections. } \\
\text { Prior to the start of the concession contract, tariffs were increased by } 38.5 \text { percent. } \\
\text { However, according to Komives and Brook-Cowen (1998) this left tariffs for low- } \\
\text { income consumers below cost. Komives (1999, 2001) reports that the concessionaire } \\
\text { managed to meet its expansions requirements in December 1998, although she noted } \\
\text { that it had mainly focused on connecting unconnected households in areas where the } \\
\text { network already reached (i.e., 'in-fill' connections) rather than expanding the network. } \\
\text { According to data from Suez-Lyonnaise des Eaux, } 57,000 \text { connections had been } \\
\text { installed by the end of } 2000 \text { (Suez-Lyonnaise des Eaux } 2001 \text { ). However, some } \\
\text { problems apparently remained with the project. In particular, Hall and Lobina (2002) } \\
\text { note that there had been press reports of protests concerning the concession. One } \\
\text { reported problem was public dissatisfaction concerning price increases, due to fees being } \\
\text { pegged to the U.S. dollar. }\end{array}$ & $\begin{array}{l}\text { Komives }(1999,2001) \\
\text { Komives and Brook-Cowen (1998) }\end{array}$ \\
\hline
\end{tabular}

Page 40 


\begin{tabular}{|c|c|c|c|c|c|}
\hline $\begin{array}{l}\text { Country } \\
\text { (City) }\end{array}$ & Year & $\begin{array}{l}\text { Case studies } \\
\text { include } \\
\text { information } \\
\text { until: }\end{array}$ & $\begin{array}{l}\text { Type of } \\
\text { Contract }\end{array}$ & Assessment & Case Studies \\
\hline $\begin{array}{l}\text { Bolivia } \\
\text { (Cochabamba) }\end{array}$ & 1999 & 2000 & $\begin{array}{l}\text { Concession } \\
\text { (40 years) }\end{array}$ & $\begin{array}{l}\text { Negative. Cancelled after Implementation } \\
\text { By 1997, the municipal utility covered only } 57 \% \text { of the population, had } 50 \% \text { losses in } \\
\text { unaccounted for water, and was severely indebted. Citizens demanded a solution to } \\
\text { Cochabamba's acute water problems, and municipal authorities followed the model } \\
\text { provided by the water concession contract in La Paz and El Alto when they initiated } \\
\text { contract negotiations in } 1997 \text {. After one botched attempt at privatization, a second } \\
\text { concession contract was signed with Aguas del Tunari (AdT) in September of } 1999 \text {. } \\
\text { Included in the contract was a guarantee to the operator of profitability. } \\
\text { Five months after the concession was granted, the population rioted against water tariff } \\
\text { increases and the contract was cancelled because of pervasive civil disorder (thus } \\
\text { returning to the former operator, SEMAPA). The Cochabamba concession fell victim to } \\
\text { the general social discontent that prevailed at the end of the decade, and ultimately failed } \\
\text { for three reasons: average tariff increases of } 35 \% \text {, confusion among small farmers that } \\
\text { they would be charged for irrigation water, and the exclusivity rights granted to AdT. } \\
\text { Consumer advocacy groups condemned the tariff increases and the contract itself, } \\
\text { claiming that they would aversely affect development. Soon, politicians that had } \\
\text { supported the privatization declared their opposition to tariff increases. The process was } \\
\text { opaque regarding the legal powers of the regulator (the Superintendencia Sectorial de } \\
\text { Saneamiento Básico, SSSB). In addition, the SSSB failed to carry out a public relations } \\
\text { campaign about the concession, and there was little consumer participation in the } \\
\text { regulatory process. AdT refused to disclose the financial model behind its price rises on } \\
\text { the grounds that the model itself was a commercial secret. }\end{array}$ & $\begin{array}{l}\text { Nickson and Vargas (2002) } \\
\text { Hall (2002)(2002) }\end{array}$ \\
\hline $\begin{array}{l}\text { Chile } \\
\text { (Santiago) }\end{array}$ & 1990 & 1996 & $\begin{array}{l}\text { Service } \\
\text { Contracts }\end{array}$ & $\begin{array}{l}\text { Positive } \\
\text { By 1990, the state-owned Santiago Metropolitan Sanitary Works Enterprise (EMOS) } \\
\text { had run into financial problems. While service was relatively good, EMOS was poorly } \\
\text { equipped to keep pace with population growth, and had operated at a loss during most of } \\
\text { the } 1980 \text { s. Rather than fully privatize EMOS, authorities chose to reform the enterprise } \\
\text { under public management. EMOS became a public stock corporation, with } 64 \% \text { owned } \\
\text { by the state development corporation and } 35 \% \text { owned by the central government. The } \\
\text { reform established a coherent legal and institutional framework as well as a transparent } \\
\text { and consistent tariff policy that offset tariff increases with direct subsidies. It improved } \\
\text { accounting and supervision substantially, establishing an independent regulator and } \\
\text { making extensive use of private service contracts. According to Rivera (1996), by } 1996 \text {, } \\
\text { EMOS was the best-performing water utility in Chile and quite possibly the best in all of } \\
\text { Latin America. Both operationally and financially, EMOS excelled, and water coverage } \\
\text { reached } 100 \% \text { by } 1991 \text {. Rivera largely credits expanded private sector participation in } \\
\text { the } 1990 \text { s for the sector's performance. Contracts were typically awarded through a } \\
\text { competitive bidding process for a period of two years, with the possibility of extension } \\
\text { at EMOS' discretion. By } 1996 \text {, more than thirty activities (valued at } \$ 13 \text { million a year, } \\
\text { and accounting for } 52 \% \text { of total operating costs) were under service contract. }\end{array}$ & $\begin{array}{l}\text { Rivera (1996) } \\
\text { Shirley, Xu and Zuluaga (2002) }\end{array}$ \\
\hline
\end{tabular}

Page 41 


\begin{tabular}{|c|c|c|c|c|c|}
\hline $\begin{array}{l}\text { Country } \\
\text { (City) }\end{array}$ & Year & $\begin{array}{l}\text { Case studies } \\
\text { include } \\
\text { information } \\
\text { until: } \\
\end{array}$ & $\begin{array}{c}\text { Type of } \\
\text { Contract }\end{array}$ & Assessment & Case Studies \\
\hline $\begin{array}{l}\text { Colombia } \\
\text { (Barranquilla) }\end{array}$ & 1991 & 1998 & $\begin{array}{c}\text { Lease } \\
\text { (20 years) }\end{array}$ & $\begin{array}{l}\text { Positive } \\
\text { Since 1960, the Municipal Public Enterprises of Barranquilla (EPM) had managed water } \\
\text { and sanitation services. Political manipulation of the EPM was rife, and the state-owned } \\
\text { firm reached technical bankruptcy by the early } 1990 \text { s. At the end of } 1990 \text {, water } \\
\text { coverage was only } 60 \% \text {. Operating expenditures consistently exceeded revenues In } \\
1991 \text {, owing to deficient service and poor management, the national government } \\
\text { supported a process of institutional transformation leading to the liquidation of the EPM } \\
\text { and the creation of the Sociedad de Acueducto, Alcantarillado y Aseo de Barranquilla, } \\
\text { S.A. (Triple A). The District of Barranquilla retained } 89 \% \text { of the shares in the newly } \\
\text { created firm and sold } 11 \% \text { to the local private sector. The private sector was involved } \\
\text { through the creation of a mixed enterprise responsible for administering the assets of the } \\
\text { system owned by the municipality. Investment remained the responsibility of the } \\
\text { district. In } 1995 \text {, the municipality reduced its ownership to } 50 \% \text {, reduced local private } \\
\text { sector participation to } 6.69 \% \text {, and gave } 43.31 \% \text { ownership to Aguas de Barcelona. } \\
\text { The control retained by the public sector appears to have been a drain on potential } \\
\text { investment as well as efficiency. The capital injected was insufficient to meet } \\
\text { investment requirements (although the situation was improved with the entrance of } \\
\text { Aguas de Barcelona). Nonetheless, service provision improved along a number of lines } \\
\text { following private sector participation. Between } 1991 \text { and } 1995 \text {, employee productivity } \\
\text { more than doubled, water coverage increased to } 83.3 \% \text {, sewerage coverage increased to } \\
68.6 \% \text {, and operating revenues moved to exceed operating expenditures. }\end{array}$ & Avendaño and Basañes (1999) \\
\hline $\begin{array}{l}\text { Colombia } \\
\text { (Cartagena) }\end{array}$ & 1995 & 2002 & $\begin{array}{c}\text { Lease } \\
\text { (26 Years) }\end{array}$ & $\begin{array}{l}\text { Positive } \\
\text { In 1995, the municipality of Cartagena signed a lease contract with Aguas de Cartagena, } \\
\text { which was partially ( } 46 \% \text { ) owned by Aguas de Barcelona (which was partially owned } \\
\text { by Suez Lyonnaise des Eaux), partially owned by other private investors ( } 4 \% \text { ) and } \\
\text { partially owned by the municipal government ( } 50 \%) \text {. The contract was negotiated } \\
\text { directly with Aguas de Barcelona and was not put out for bidding. The new company } \\
\text { was given control of a major sector investment program, which was financed with a } \\
\text { municipal loan (from the World Bank and Inter-American Development Bank). In } \\
\text { addition to its participation as a shareholder, Aguas de Barcelona also signed a } \\
\text { management contract with Aguas de Cartagena, for which it received a fixed share of } \\
\text { sector revenues. } \\
\text { Sector performance improved following the introduction of private sector participation. } \\
\text { The number of connections increased by } 30,000 \text { during the first five years of the lease, } \\
\text { unaccounted for water was reduced, and water quality has reportedly improved (with } \\
\text { water availability rising from an average of } 7 \text { hours per day in } 1994 \text { to } 24 \text { hours per day } \\
\text { in 2002). One problem has been that collection has remained problematic. }\end{array}$ & $\begin{array}{l}\text { Rivera (1996) } \\
\text { Nickson (2001b) } \\
\text { Beato and Díaz (2003) } \\
\text { Avendaño and Basañes (1999) }\end{array}$ \\
\hline
\end{tabular}

Page 42 


\begin{tabular}{|c|c|c|c|c|c|}
\hline $\begin{array}{l}\text { Country } \\
\text { (City) }\end{array}$ & Year & $\begin{array}{c}\text { Case studies } \\
\text { include } \\
\text { information } \\
\text { until: }\end{array}$ & $\begin{array}{l}\text { Type of } \\
\text { Contract }\end{array}$ & Assessment & Case Studies \\
\hline $\begin{array}{l}\text { Colombia } \\
\text { (Marinilla) }\end{array}$ & 1997 & 2000 & $\begin{array}{l}\text { Service } \\
\text { Contracts }\end{array}$ & $\begin{array}{l}\text { Positive } \\
\text { In 1991, Colombia's new constitution legalized private sector participation in water } \\
\text { service provision. Of Colombia's } 1091 \text { municipalities, } 1070 \text { are considered small and } \\
\text { medium cities, with populations between } 2,000 \text { and } 100,000 \text {. By } 2001 \text {, Public Service } \\
\text { Companies-some public, some private-serviced only } 6 \% \text { of Colombia's small cities } \\
\text { (those with a population between } 2,000 \text { and } 30,000 \text { ). The remainder received water } \\
\text { directly from the municipality, or from state-owned enterprises. One province in which } \\
\text { private sector participation was substantially increased during the } 1990 \text { s was Antioquia. } \\
\text { Throughout the decade, municipal authorities in Antioquia began signing service } \\
\text { contracts with small and medium-sized private operators. By } 2000 \text {, } 38 \text { of Antioquia's } \\
125 \text { municipalities were serviced by a total of } 11 \text { private operators. Typical of the small } \\
\text { cities of Antioquia that introduced private sector participation was Marinilla. } \\
\\
\text { In Marinilla (pop. } 26,000 \text { ), a private local company, CONHYDRA, began operation in } \\
\text { 1997. In its service contract, CONHYDRA agreed to meet a number of goals with } \\
\text { respect to coverage and quality of services. This contract appeared to have a great deal } \\
\text { of success. Coverage of both water and sewerage services as well as total production } \\
\text { increased substantially by } 2000 \text {, while unaccounted for water decreased. CONHYDRA } \\
\text { enjoyed good relations with municipal authorities as well as consumers, and the rate of } \\
\text { satisfaction with service provision increased to } 93 \% \text { in } 2000 \text {. Marinilla has since } \\
\text { become a model of private sector participation in the operation of water and sewerage } \\
\text { services in Colombia's small and medium-sized cities. }\end{array}$ & $\begin{array}{l}\text { Arévalo and Schippner (2002) } \\
\text { Avendaño and Basañes (1999) }\end{array}$ \\
\hline $\begin{array}{l}\text { Colombia } \\
\text { (Montería) }\end{array}$ & 1994 & 1997 & Lease & $\begin{array}{l}\text { Positive } \\
\text { In 1994, the Monería City Council authorized the liquidation of the Municipal Public } \\
\text { Enterprises of Montería (EPM), which was created in } 1955 \text { to provide water and } \\
\text { sewerage services. In its place, municipal authorities created a mixed enterprise with the } \\
\text { exclusive responsibility of providing water and sewerage services - the Sociedad de } \\
\text { Acueducto y Alcantarillado de Montería-SAAM, S.A.. The municipality stipulated } \\
\text { that the public sector could hold no more than } 49 \% \text { of the shares in the new, mixed } \\
\text { enterprise. While the municipality retained control of the assets, SAMM was } \\
\text { responsible for management, administration, and service provision. In return for use of } \\
\text { the assets, the enterprise was required to pay an annual sum equal to } 10 \% \text { of the total } \\
\text { revenues from billings. } \\
\text { Private sector participation did not bring immediate investment, but a legacy of poor } \\
\text { administration left the sector in dire need of new capital. While coverage was at } 65 \% \text {, } \\
\text { water was supplied, on average, for only } 3 \text { hours per day. Nonetheless, only } \$ 300,000 \\
\text { was spent on capitalization in the years immediately following the creation of SAAM. } \\
\text { Despite low investment, however, private sector involvement had a number of positive } \\
\text { effects on efficiency, and the system generally improved. Management was now } \\
\text { significantly less politicized, and the size of the bureaucracy was considerably reduced. } \\
\text { Among similar Colombian enterprises, SAAM had the lowest administrative costs in the } \\
\text { country. Indeed, the number of workers for every } 1,000 \text { connections was reduced from } \\
9.8 \text { in } 1992 \text { to } 0.3 \text { in } 1997 \text {. Water coverage also rose, from } 65 \% \text { in } 1992 \text { to } 75 \% \text { in } 1997 \text {. }\end{array}$ & Avendaño and Basañes (1999) \\
\hline
\end{tabular}

Page 43 


\begin{tabular}{|c|c|c|c|c|c|}
\hline $\begin{array}{l}\text { Country } \\
\text { (City) }\end{array}$ & Year & $\begin{array}{l}\text { Case studies } \\
\text { include } \\
\text { information } \\
\text { until: }\end{array}$ & $\begin{array}{l}\text { Type of } \\
\text { Contract }\end{array}$ & Assessment & Case Studies \\
\hline $\begin{array}{l}\text { Honduras } \\
\text { (San Pedro } \\
\text { Sula) }\end{array}$ & 2003 & 2002 & $\begin{array}{l}\text { Concession } \\
\text { (30 Years) }\end{array}$ & $\begin{array}{l}\text { Positive } \\
\text { In October of 2000, municipal authorities granted a } 30 \text { year concession to the private } \\
\text { firm Aguas de San Pedro to provide potable water and sewerage services to San Pedro } \\
\text { Sula. The municipality had provided these services since the } 1970 \text { s, first through a } \\
\text { water department and later through the Municipal Division of Water (DIMA). Tariffs } \\
\text { that had been set without regard to costs and then frozen, preventing DIMA from } \\
\text { undertaking investments needed to keep up with the city's growth in the 1990s. As the } \\
\text { DIMA's debt increased, municipal authorities decided to privatize. } \\
\text { In the concession contract, Aguas de San Pedro agreed to an initial tariff rate lower than } \\
\text { the pre-privatization rate, with plans to raise the tariff } 20 \% \text { after three years. The firm } \\
\text { agreed to invest an estimated } \$ 208 \text { million to achieve targets including } 100 \% \text { water } \\
\text { coverage within three years (up from } 82 \% \text { at the time of privatization), } 100 \% \text { sewerage } \\
\text { coverage within six years (up from } 66 \% \text { ), and } 100 \% \text { treatment within four years. By the } \\
\text { end of } 2002 \text {, water coverage had increased to } 92 \% \text {, sewerage coverage to } 66 \% \text {, and } \\
\text { water treatment to } 15.54 \% \text {. }\end{array}$ & Díaz (2003) \\
\hline $\begin{array}{l}\text { México } \\
\text { (Cancún and } \\
\text { Isla Mujeres) }\end{array}$ & 1994 & 1996 & $\begin{array}{l}\text { Concession } \\
\text { (30 years) }\end{array}$ & $\begin{array}{l}\text { Little immediate progress } \\
\text { In 1983, a constitutional reform placed each municipality in charge of water and } \\
\text { sanitation provision. The municipality of Benito Juárez charged a state organization, the } \\
\text { Comisión de Agua Potable y Alcantarillado (Water and Sanitation Commission, or } \\
\text { CAPA) with this responsibility. In 1991, CAPA signed a 14-year build-operate-transfer } \\
\text { contract with Desarrollos Hidráulicos de Cancún (DHC), a subsidiary of the private firm } \\
\text { Grupo Mexicano de Desarrollo. DHC was contracted to build and operate a new well } \\
\text { production system in Cancún, necessitated by enormous population growth. The BOT } \\
\text { agreement, however, did not generate sufficient investment. In 1993, the state, CAPA, } \\
\text { and municipal authorities petitioned four firms to present proposals for the expansion, } \\
\text { operation, and maintenance of the water and wastewater system in Cancún and Isla } \\
\text { Mujeres. DHC won a } 30 \text {-year concession and created the firm AGUAKAN to operate } \\
\text { the system starting in January of } 1994 \text {. The firm would pay CAPA an annual concession } \\
\text { fee of } \$ 1 \text { million and the federal water agency an annual water extraction fee. } \\
\\
\text { During the first two years, the concessionaire failed to meet targets and did not adhere to } \\
\text { its investment plan, leading to popular discontent. The lack of a systemic mechanism } \\
\text { for setting tariffs led to inefficient pricing. While production increased from } 44 \text { million } \\
\text { to } 47 \text { million cubic meters per year between } 1993 \text { and } 1995 \text {, unaccounted for water } \\
\text { remained high, at } 51 \% \text {. As of } 1996 \text {, AGUAKAN was contracting to add } 10,000 \text { new } \\
\text { water connections and } 79 \text { km of sewerage pipeline. This would increase water and } \\
\text { sewerage coverage from } 63 \% \text { to } 74 \% \text { and } 35 \% \text { to } 45 \% \text {, respectively, by the end of } \\
1996 \text {. The works remained inactive due to insufficient funds. According to Rivera } \\
\text { (1996), AGUAKAN's meager performance is explained by four factors: the } \\
\text { macroeconomic crisis of } 1994-95 \text {, the weakness of the regulatory regime, the fact that } \\
\text { high costs were passed on to consumers without sufficient attempts to increase } \\
\text { efficiency, and the concessionaire's lack of knowledge about the sector. }\end{array}$ & Rivera (1996) \\
\hline
\end{tabular}

Page 44 


\begin{tabular}{|c|c|c|c|c|c|}
\hline $\begin{array}{l}\text { Country } \\
\text { (City) }\end{array}$ & Year & $\begin{array}{c}\text { Case studies } \\
\text { include } \\
\text { information } \\
\text { until: } \\
\end{array}$ & $\begin{array}{c}\text { Type of } \\
\text { Contract }\end{array}$ & Assessment & Case Studies \\
\hline $\begin{array}{l}\text { México } \\
\text { (México City) }\end{array}$ & 1993 & 1998 & $\begin{array}{l}\text { Service } \\
\text { Contracts }\end{array}$ & $\begin{array}{l}\text { Positive. However, benefits were very modest. } \\
\text { The reform enacted in Mexico City involved only minor private sector participation. } \\
\text { The private companies. In a three-stage process, private companies would first complete } \\
\text { a customer census, map the network and install meters. In a second stage, they would } \\
\text { assume responsibility for billing, participate in bill collection, establish customer care } \\
\text { centers, and connect new customers. In the third and final stage, they would become } \\
\text { responsible for some aspects of operation and maintenance. Although the third stage was } \\
\text { supposed to begin about two years after the contract was signed, there were serious } \\
\text { delays. Furthermore, contract renegotiations in } 1998 \text { appear to have reduced the extent } \\
\text { of private sector involvement in the third stage of reform. } \\
\text { Despite these problems, the contracts appear to have some success. In particular, } \\
\text { Haggarty et al. (2002) note that the private operators managed to improve billing, } \\
\text { regularize many unbilled connections, and install over } 1 \text { million meters. In addition, } \\
\text { some measures of service quality have also improved. However, the minor reform } \\
\text { failed to improve performance along many other dimensions. Although the number of } \\
\text { registered connections increased by about } 300,000 \text { during the contract period -leading to } \\
\text { an improvement in the number of employees per } 1000 \text { connections, this appears to have } \\
\text { primarily been the result of the regularization of unregistered connections. } \\
\text { Consequently, in practice, the modest reform failed to reduce operating costs and failed } \\
\text { to introduce a pricing scheme that would curb residential consumption. Given that } \\
\text { subsidence due to overexploitation of the aquifer is a serious problem in Mexico City, } \\
\text { this could impose serious social costs. }\end{array}$ & Haggarty, Brook and Zuluaga (2002) \\
\hline $\begin{array}{l}\text { Trinidad and } \\
\text { Tobago (All) }\end{array}$ & 1996 & 1998 & $\begin{array}{l}\text { Management } \\
\text { Contract } \\
\text { (3 years) }\end{array}$ & $\begin{array}{l}\text { Negative (Contract not renewed). } \\
\text { Description: Management Contract (3-years). The Water and Sewerage Authority } \\
\text { (WASA) of Trinidad and Tobago was publicly owned until 1996, when a lack of funding } \\
\text { and the need for effective management led to private sector involvement. The government } \\
\text { opted for a two-phase plan. In the first phase a private operator would sign a management } \\
\text { contract with the government. After this interim phase, the contract would be converted to a } \\
\text { long-term concession ( } 20-30 \text { years). At this time, the incumbent operator would have first } \\
\text { rights of negotiation. } \\
\text { Outcome: There were some improvements in performance, although these were generally } \\
\text { more modest that originally hoped for. The total number of connections increased from } \\
200,000 \text { to 300,000; the number of employees per } 1000 \text { connections fell from } 17 \text { to } 9 \text {. } \\
\text { However, these improvements were short-lived and performance deteriorated after the } \\
\text { contract ended. Further, the private management had a poor relationship with the company's } \\
\text { board and the government and, ultimately the contract was not renewed.. }\end{array}$ & $\begin{array}{l}\text { Nankani (1997) } \\
\text { Stiggers (1999) }\end{array}$ \\
\hline
\end{tabular}

Note: Assessments of outcomes only include information up to the most recent information available in the case studies cities. 
Table A2: Effect of Reforms Involving Private Sector Participation on Sector Performance, Quantitative Measures of Performance

\begin{tabular}{|c|c|c|c|c|c|c|c|c|}
\hline \multirow[b]{2}{*}{$\begin{array}{l}\text { Country } \\
\text { (City) }\end{array}$} & \multirow[b]{2}{*}{ Year } & \multirow[b]{2}{*}{$\begin{array}{l}\text { Type of } \\
\text { Contract }\end{array}$} & \multicolumn{5}{|c|}{ Effect of Reform Involving Private Sector Participation } & \multirow[t]{2}{*}{ Case Studies } \\
\hline & & & Prices & $\begin{array}{l}\text { Coverage } \\
(000 \text { s of } \\
\text { Connections) }\end{array}$ & $\begin{array}{l}\text { Production } \\
\text { (Million } \mathrm{m}^{3} / \mathrm{yr} \text { ) }\end{array}$ & $\begin{array}{l}\text { Unaccounted } \\
\text { for Water } \\
\text { (\% of } \\
\text { Production) } \\
\end{array}$ & $\begin{array}{l}\text { Productivity } \\
\text { (Workers per } \\
1000 \\
\text { connections) } \\
\end{array}$ & \\
\hline \multicolumn{9}{|l|}{ Africa } \\
\hline $\begin{array}{l}\text { Côte d'Ivoire } \\
\text { (All) }\end{array}$ & $1988^{\mathrm{a}}$ & Lease & $\begin{array}{l}\text { DECREASED } \\
\text { Between } 1987 \text { and 1997, } \\
\text { average tariffs fell about } \\
36 \% \text { in real terms. }\end{array}$ & $\begin{array}{l}\text { INCREASED } \\
\text { 1987: } 201.0 \\
\text { 1996: } 345.0 \\
\text { 2000: } 630.0\end{array}$ & $\begin{array}{l}\text { INCREASED } \\
\text { 1987: } 90 \\
\text { 1996: } 118 \\
\text { 2000: } 138\end{array}$ & $\begin{array}{l}\text { INCREASED } \\
\text { 1987: } 13 \% \\
\text { 1996: } 16 \% \\
\text { 2000: } 16 \%\end{array}$ & $\begin{array}{l}\text { IMPROVED } \\
\text { 1987: } 8.3 \\
\text { 1996: } 3.8 \\
\text { 2000: } 2.4\end{array}$ & $\begin{array}{l}\text { Kerf }(2000) \\
\text { Menard and Clarke (2002a) } \\
\text { Trémolet, Browning and Howard } \\
(2002)\end{array}$ \\
\hline Gabon (All) & 1997 & Concession & $\begin{array}{l}\text { DECREASED. } \\
\text { On average, tariffs were } \\
\text { reduced } 17.5 \% \text { at time of } \\
\text { privatization. }\end{array}$ & $\begin{array}{l}\text { INCREASED. } \\
\text { 1997: } 59.8 \\
\text { 2000: } 72.6\end{array}$ & $\begin{array}{l}\text { INCREASED } \\
\text { 1997: } 42.1 \\
\text { 2000: } 50.0\end{array}$ & $\begin{array}{l}\text { UNKNOWN } \\
\text { 1997: --- } \\
\text { 2000: } \sim 14 \%\end{array}$ & $\begin{array}{l}\text { IMPROVED } \\
\text { Trémolet and } \\
\text { Neale (2002, p. } \\
\text { 49) report that } \\
\text { total } \\
\text { employment } \\
\text { (including in } \\
\text { electricity } \\
\text { sector) was } \\
\text { similar in } 1997 \\
\text { (about } 1500 \text { ) } \\
\text { and 2000 (about } \\
\text { 1450-1500). } \\
\text { This suggests } \\
\text { that workers per } \\
\text { connections } \\
\text { fell. }\end{array}$ & Trémolet and Neale (2002) \\
\hline Gambia (All) & 1993 & Lease & --- & $\begin{array}{l}\text { INCREASED } \\
\text { Kerf (2000) } \\
\text { reports } \\
\text { improvements } \\
\text { but does not } \\
\text { provide any } \\
\text { data. } \\
\end{array}$ & $\begin{array}{l}\text { INCREASED } \\
\text { Kerf (2000) reports } \\
\text { improvements but } \\
\text { does not provide } \\
\text { data. }\end{array}$ & $\begin{array}{l}\text { DECREASED } \\
\text { Kerf (2000) } \\
\text { reports } \\
\text { improvements } \\
\text { but does not } \\
\text { provide any } \\
\text { data. } \\
\end{array}$ & --- & $\operatorname{Kerf}(2000)$ \\
\hline
\end{tabular}




\begin{tabular}{|c|c|c|c|c|c|c|c|c|}
\hline \multirow[b]{2}{*}{$\begin{array}{l}\text { Country } \\
\text { (City) }\end{array}$} & \multirow[b]{2}{*}{ Year } & \multirow[b]{2}{*}{$\begin{array}{l}\text { Type of } \\
\text { Contract }\end{array}$} & \multicolumn{5}{|c|}{ Effect of Reform Involving Private Sector Participation } & \multirow[t]{2}{*}{ Case Studies } \\
\hline & & & Prices & $\begin{array}{l}\text { Coverage } \\
\text { (000s of } \\
\text { Connections) }\end{array}$ & $\begin{array}{l}\text { Production } \\
\left(\text { Million } \mathrm{m}^{3} / \mathrm{yr}\right)\end{array}$ & $\begin{array}{l}\text { Unaccounted } \\
\text { for Water } \\
\text { (\% of } \\
\text { Production) }\end{array}$ & $\begin{array}{l}\text { Productivity } \\
\text { (Workers per } \\
1000 \\
\text { connections) }\end{array}$ & \\
\hline Guinea (All) & 1989 & Lease & $\begin{array}{l}\text { INCREASED } \\
\text { Prices increased } \\
\text { significantly following } \\
\text { reform. The average tariff } \\
\text { for a cubic meter increased } \\
\text { over } 450 \text { percent in real } \\
\text { terms between } 1988 \text { and } \\
1996 \text { (i.e., by the time } \\
\text { subsidies were ended). }\end{array}$ & $\begin{array}{l}\text { INCREASED } \\
\text { 1988: } 12.0 \\
\text { 1997: } 31.0 \\
\text { 2000: } 58.8\end{array}$ & $\begin{array}{l}\text { INCREASED } \\
\text { 1989: } 16.4 \\
\text { 1996: } 22.1 \\
\text { 2000: } 26.2\end{array}$ & $\begin{array}{l}\text { UNKNOWN } \\
\text { Before reform, } \\
\text { in the absence } \\
\text { of metering, } \\
\text { estimates of } \\
\text { UFW varied } \\
\text { widely } \\
\text { 1989: } 35-60 \% \\
\text { 2000: } 38.6 \%\end{array}$ & $\begin{array}{l}\text { IMPROVED } \\
\text { 1988: } 42.0 \\
1996: 23.3 \\
2000: 7.3\end{array}$ & $\begin{array}{l}\text { Book Cowen (1999) } \\
\text { Brook and Lucussol (2001) } \\
\text { Clarke, Ménard and Zuluaga (2002) } \\
\text { Kerf (2000) } \\
\text { Ménard and Clarke (2002b) } \\
\text { Rivera (1996) }\end{array}$ \\
\hline Senegal (All) & 1996 & Lease & $\begin{array}{l}\text { INCREASED } \\
\text { By about } 3 \text { percent per } \\
\text { year. }\end{array}$ & $\begin{array}{l}\text { INCREASED } \\
\text { 1995: } 204.0 \\
\text { 1999: } 286.0 \\
\text { 2001: } 294.0\end{array}$ & $\begin{array}{l}\text { INCREASED } \\
\text { 1995: } 69.4 \\
\text { 1999: } 74.8\end{array}$ & $\begin{array}{l}\text { DECREASED } \\
\text { 1995: } 31.8 \% \\
\text { 1999: } 26.0 \% \\
\text { 2001: } 22.0 \%\end{array}$ & $\begin{array}{l}\text { IMPROVED } \\
\text { 1996: } 6.3 \\
2000: 4.3\end{array}$ & $\begin{array}{l}\text { Kerf }(2000) \\
\text { Trémolet, Browning and Howard } \\
(2002) \\
\text { World Bank (2001) }\end{array}$ \\
\hline $\begin{array}{l}\text { South Africa } \\
\text { (Queenstown) }\end{array}$ & 1992 & Concession & $\begin{array}{l}\text { UNKNOWN } \\
\text { Sohail's interviews } \\
\text { indicate that bills were } \\
71 \% \text { more expensive in } \\
\text { Mlungisi and } 70 \% \text { more } \\
\text { expensive in Ezibeleni }\end{array}$ & $\begin{array}{l}\text { UNKNOWN } \\
\text { It is unclear } \\
\text { what portion of } \\
\text { the rise in } \\
\text { connections } \\
\text { reflects the } \\
\text { expansion of } \\
\text { the municipal } \\
\text { area itself (to } \\
\text { incorporate two } \\
\text { new areas) and } \\
\text { which portion } \\
\text { reflects the } \\
\text { connection of } \\
\text { the previously } \\
\text { unconnected. } \\
\text { Sohail reports } \\
\text { that coverage } \\
\text { was already } \\
\text { high at the time } \\
\text { of privatization, } \\
\text { and did not } \\
\text { change } \\
\text { significantly }\end{array}$ & --- & $\begin{array}{l}\text { DECREASED } \\
\text { 1995: } 45 \% \\
1999: 21 \%\end{array}$ & --- & Sohail (2000) \\
\hline
\end{tabular}




\begin{tabular}{|c|c|c|c|c|c|c|c|c|}
\hline \multirow[b]{2}{*}{$\begin{array}{l}\text { Country } \\
\text { (City) }\end{array}$} & \multirow[b]{2}{*}{ Year } & \multirow[b]{2}{*}{$\begin{array}{l}\text { Type of } \\
\text { Contract }\end{array}$} & \multicolumn{5}{|c|}{ Effect of Reform Involving Private Sector Participation } & \multirow[t]{2}{*}{ Case Studies } \\
\hline & & & Prices & $\begin{array}{l}\text { Coverage } \\
\text { (000s of } \\
\text { Connections) }\end{array}$ & $\begin{array}{l}\text { Production } \\
\text { (Million } \mathrm{m}^{3} / \mathrm{yr} \text { ) }\end{array}$ & $\begin{array}{l}\text { Unaccounted } \\
\text { for Water } \\
\text { (\% of } \\
\text { Production) }\end{array}$ & $\begin{array}{l}\text { Productivity } \\
\text { (Workers per } \\
1000 \\
\text { connections) }\end{array}$ & \\
\hline $\begin{array}{l}\text { Philippines } \\
\text { (Manila) }\end{array}$ & 1997 & $\begin{array}{l}\text { Two } \\
\text { Concessions } \\
\text { (Both for } 25 \\
\text { years) }\end{array}$ & $\begin{array}{l}\text { DECREASED } \\
\text { Porter (2001) reports that } \\
\text { the contract forbade real } \\
\text { tariff increases for } 5 \text { years, } \\
\text { excluding "Extraordinary } \\
\text { Price Adjustments (EPAs). } \\
\text { In 1998, both } \\
\text { concessionaires } \\
\text { submitted EPAs following } \\
\text { devaluation and draught. } \\
\text { Nonetheless, neither } \\
\text { requested an increase that } \\
\text { would produce tariffs } \\
\text { exceeding pre-privatization } \\
\text { levels. }\end{array}$ & $\begin{array}{l}\text { INCREASED } \\
\text { 1995: } 825 \\
\text { 2001: } 1,030\end{array}$ & $\begin{array}{l}\text { INCREASED } \\
\text { 1995: } 3000 \mathrm{mld} \\
\text { 2001: } 4142 \mathrm{mld}\end{array}$ & $\begin{array}{l}\text { SIMILAR } \\
\text { 1990: } 56 \% \\
\text { 1991: } 54 \% \\
\text { 1992: } 55 \% \\
\text { 1993: } 57 \% \\
\text { 1994: } 59 \% \\
\text { 1995: 56\% } \\
\text { 1996: } 56 \% \\
\text { 2001: } 57 \%\end{array}$ & $\begin{array}{l}\text { IMPROVED } \\
\text { 1995: } 9.8 \\
\text { 2001: } 4.0\end{array}$ & $\begin{array}{l}\text { Dumol (2000) } \\
\text { Santos (2003) } \\
\text { Porter (2001) }\end{array}$ \\
\hline \multicolumn{9}{|c|}{ toris. } \\
\hline $\begin{array}{l}\text { Poland } \\
\text { (Gdansk) }\end{array}$ & 1992 & $\begin{array}{l}\text { Lease }(30 \\
\text { years) }\end{array}$ & $\begin{array}{l}\text { UNKNOWN } \\
\text { Rivera (1996) reports that } \\
\text { between } 1992 \text { and 1995, } \\
\text { four annual tariff increases } \\
\text { occurred. None, however, } \\
\text { kept pace with inflation. } \\
\text { Finally, in 1996, a fifth, } \\
20 \% \text { tariff increase was } \\
\text { approved, and further } \\
\text { increases were under } \\
\text { negotiation. }\end{array}$ & $\begin{array}{l}\text { UNCHANGE } \\
\text { D } \\
\text { Rivera (1996) } \\
\text { reports that the } \\
\text { population } \\
\text { served and the } \\
\text { number of } \\
\text { water and } \\
\text { sewerage } \\
\text { connections } \\
\text { remained } \\
\text { essentially } \\
\text { unchanged } \\
\text { following the } \\
\text { lease agreement }\end{array}$ & $\begin{array}{l}\text { DECREASED } \\
\text { Rivera (1996) reports } \\
\text { that water production } \\
\text { fell more than } 20 \% \\
\text { between } 1993 \text { and } \\
1995, \text { mainly as a } \\
\text { result of tariff } \\
\text { increases and meter } \\
\text { installation, which } \\
\text { decreased } \\
\text { consumption. }\end{array}$ & $\begin{array}{l}\text { UNKNOWN } \\
\text { 1995: } 20 \%\end{array}$ & $\begin{array}{l}\text { IMPROVED } \\
\text { 1992: } 10.3 \\
\text { 1995: } 8.0\end{array}$ & Rivera (1996) \\
\hline $\begin{array}{l}\text { Latin } \\
\text { America }\end{array}$ & & & & & & & & \\
\hline
\end{tabular}




\begin{tabular}{|c|c|c|c|c|c|c|c|c|}
\hline \multirow[b]{2}{*}{$\begin{array}{l}\text { Country } \\
\text { (City) }\end{array}$} & \multirow[b]{2}{*}{ Year } & \multirow[b]{2}{*}{$\begin{array}{l}\text { Type of } \\
\text { Contract }\end{array}$} & \multicolumn{5}{|c|}{ Effect of Reform Involving Private Sector Participation } & \multirow[t]{2}{*}{ Case Studies } \\
\hline & & & Prices & $\begin{array}{l}\text { Coverage } \\
\text { ( } 000 \text { s of } \\
\text { Connections) }\end{array}$ & $\begin{array}{l}\text { Production } \\
\text { (Million } \mathrm{m}^{3} / \mathrm{yr} \text { ) }\end{array}$ & $\begin{array}{l}\text { Unaccounted } \\
\text { for Water } \\
\text { (\% of } \\
\text { Production) } \\
\end{array}$ & $\begin{array}{l}\text { Productivity } \\
\text { (Workers per } \\
1000 \\
\text { connections) } \\
\end{array}$ & \\
\hline $\begin{array}{l}\text { Argentina } \\
\text { (Buenos } \\
\text { Aires) }\end{array}$ & 1993 & Concession & $\begin{array}{l}\text { DECREASED } \\
\text { (initially) } \\
\text { Prices were reduced by } \\
\text { about } 27 \% \text { at the time that } \\
\text { the contract was } \\
\text { implemented. However, } \\
\text { after this, prices were } \\
\text { increased several times, } \\
\text { including a } 13 \% \text { increase } \\
\text { in } 1994 \text { and a } 19 \% \text { increase } \\
\text { in } 1997 \text { during contract } \\
\text { renegotiations. }\end{array}$ & $\begin{array}{l}\text { INCREASED } \\
\text { 1992: } 2,290.0 \\
\text { 1995: } 2,412.0 \\
\text { 1998: } 2,583.0\end{array}$ & $\begin{array}{l}\text { INCREASED } \\
\text { 1992: } 1378.0 \\
\text { 1995: } 1400.0 \\
\text { 1998: } 1437.0\end{array}$ & $\begin{array}{l}\text { DECREASED } \\
1992: 44.0 \% \\
1995: 34.0 \% \\
1998: 34.0 \%\end{array}$ & $\begin{array}{l}\text { IMPROVED } \\
\text { 1992: } 3.4 \\
\text { 1995: } 1.6 \\
\text { 1998: } 1.7\end{array}$ & $\begin{array}{l}\text { (1997) } \\
\text { Alcázar, Abdala and Shirley (2002) } \\
\text { Artana, Navajas and Urbiztondo } \\
\text { (1999) } \\
\text { Rivera (1996) Abdala }\end{array}$ \\
\hline $\begin{array}{l}\text { Argentina } \\
\text { (Córdoba) }\end{array}$ & 1997 & Concession & $\begin{array}{l}\text { DECREASED } \\
\text { Tariffs were reduced by } \\
8.2 \% \text { at the start of the } \\
\text { concession }\end{array}$ & $\begin{array}{l}\text { INCREASED } \\
\text { 1997: } 208.5 \\
\text { 1999: } 223.5\end{array}$ & 1999: 140.0 & $\begin{array}{l}\text { DECREASED } \\
\text { Nickson (2001) } \\
\text { reports a } \\
\text { reduction in } \\
\text { leaks, but does } \\
\text { not provide } \\
\text { UFW rates } \\
\end{array}$ & $\begin{array}{l}\text { IMPROVED } \\
\text { 1997: } 6.2 \\
\text { 1999: } 2.0\end{array}$ & Nickson (2001a) \\
\hline $\begin{array}{l}\text { Argentina } \\
\text { (Corrientes) }\end{array}$ & 1992 & Concession & $\begin{array}{l}\text { SIMILAR } \\
\text { Average rates per cubic } \\
\text { meter of water increased } \\
\text { from US } \$ 0.33 \text { to US\$0.36 } \\
\text { between } 1991 \text { and } 1996 \text {. } \\
\text { This implies a very small } \\
\text { decrease in real terms. }\end{array}$ & $\begin{array}{l}\text { INCREASED } \\
\text { 1991: } 80.0 \\
\text { 1996: } 105.0\end{array}$ & $\begin{array}{l}\text { DECREASED } \\
\text { 1991: } 61.5 \\
\text { 1995: } 55.1 \\
\begin{array}{l}\text { Decrease in } \\
\text { production due to } \\
\text { improved UFW and } \\
\text { reduced consumption } \\
\text { due to metering }\end{array} \\
\end{array}$ & $\begin{array}{l}\text { DECREASED } \\
\text { 1991: } 61 \% \\
\text { 1996: } 45 \%\end{array}$ & $\begin{array}{l}\text { IMPROVED } \\
\text { 1991: } 7.4 \\
\text { 1996: } 2.6\end{array}$ & $\begin{array}{l}\text { Artana, Navajas and Urbiztondo } \\
\text { (1999) }\end{array}$ \\
\hline $\begin{array}{l}\text { Argentina } \\
\text { (Salta) }\end{array}$ & 1998 & Concession & $\begin{array}{l}\text { INCREASED } \\
\text { On average, tariffs } \\
\text { increased by } 14 \% \text { between } \\
1998 \text { and } 2002\end{array}$ & $\begin{array}{l}\text { INCREASED } \\
\text { 1998: } 173.7 \\
\text { 2002: } 241.3\end{array}$ & $\begin{array}{l}\text { INCREASED } \\
\text { 1998: } 130.0 \\
\text { 2002: } 165.0\end{array}$ & --- & --- & Saltiel (2003) \\
\hline $\begin{array}{l}\text { Argentina } \\
\text { (Tucumán) }\end{array}$ & 1995 & Concession & $\begin{array}{l}\text { INCREASED } \\
\text { On average, tariffs were } \\
\text { increased by } 107 \% \text { at the } \\
\text { time of privatization }\end{array}$ & --- & --- & --- & --- & $\begin{array}{l}\text { Rais, Esquivel and Sour (2002) } \\
\text { Artana, Navajas and Urbiztondo } \\
\text { (1998) }\end{array}$ \\
\hline
\end{tabular}




\begin{tabular}{|c|c|c|c|c|c|c|c|c|}
\hline \multirow[b]{2}{*}{$\begin{array}{l}\text { Country } \\
\text { (City) }\end{array}$} & \multirow[b]{2}{*}{ Year } & \multirow[b]{2}{*}{$\begin{array}{l}\text { Type of } \\
\text { Contract }\end{array}$} & \multicolumn{5}{|c|}{ Effect of Reform Involving Private Sector Participation } & \multirow[t]{2}{*}{ Case Studies } \\
\hline & & & Prices & $\begin{array}{l}\text { Coverage } \\
\text { (000s of } \\
\text { Connections) }\end{array}$ & $\begin{array}{l}\text { Production } \\
\text { (Million } \mathrm{m}^{3} / \mathrm{yr} \text { ) }\end{array}$ & $\begin{array}{l}\text { Unaccounted } \\
\text { for Water } \\
\text { (\% of } \\
\text { Production) } \\
\end{array}$ & $\begin{array}{l}\text { Productivity } \\
\text { (Workers per } \\
1000 \\
\text { connections) } \\
\end{array}$ & \\
\hline $\begin{array}{l}\text { Bolivia } \\
\text { (Cochabamba) }\end{array}$ & 1999 & Concession & $\begin{array}{l}\text { INCREASED } \\
\text { On average, tariffs } \\
\text { increased by } 35 \% \text { at the } \\
\text { time of privatization (with } \\
\text { an additional } 20 \% \text { increase } \\
\text { planned for } 2002 \text { ) }\end{array}$ & --- & --- & $\begin{array}{l}\text { DECREASED } \\
\text { 1997: } 50 \% \\
\text { Nickson reports } \\
\text { a reduction in } \\
\text { leaks, but does } \\
\text { not provide } \\
\text { rates after the } \\
\text { concession }\end{array}$ & $\begin{array}{l}\text { UNKNOWN } \\
1997: 4.7\end{array}$ & $\begin{array}{l}\text { Nickson and Vargas (2002) } \\
\text { Hall (2002) }\end{array}$ \\
\hline $\begin{array}{l}\text { Chile } \\
\text { (Santiago) }\end{array}$ & 1990 & $\begin{array}{l}\text { Service } \\
\text { Contracts }\end{array}$ & $\begin{array}{l}\text { INCREASED } \\
\text { On average, tariffs } \\
\text { increased by } 41 \% \text { between } \\
1990 \text { and } 1994 \text {. However, } \\
\text { price increases were } \\
\text { accompanied by a direct } \\
\text { subsidy, mitigating their } \\
\text { effects. } \\
1994: \$ 0.29 / \mathrm{m}^{3}\end{array}$ & $\begin{array}{l}\text { INCREASED } \\
\text { Water: } \\
\text { 1990: } 837 \\
\text { (99\%) } \\
\text { 1991: } 867 \\
(100 \%) \\
\text { 1992: } 905 \\
(100 \%) \\
\text { 1993: } 944 \\
(100 \%) \\
\text { 1994: } 985 \\
(100 \%) \\
\text { Sewerage: } \\
\text { 1990: } 777 \\
(91 \%) \\
\text { 1991: } 807 \\
\text { (93\%) } \\
\text { 1992: } 868 \\
(95 \%) \\
\text { 1993: } 915 \\
(97 \%) \\
\text { 1994: } 956 \\
(97 \%)\end{array}$ & $\begin{array}{l}\text { INCREASED } \\
\text { 1990: } 462 \\
\text { 1991: } 453 \\
\text { 1992: } 466 \\
\text { 1993: } 469 \\
\text { 1994: } 475\end{array}$ & $\begin{array}{l}\text { DECREASED } \\
\text { 1990: } 28 \% \\
\text { 1991: } 27 \% \\
\text { 1992: } 27 \% \\
\text { 1993: } 24 \% \\
\text { 1994: } 22 \%\end{array}$ & $\begin{array}{l}\text { IMPROVED } \\
\text { 1990: } 2.1 \\
\text { 1994: } 1.9 \\
\text { 1996: } 1.75\end{array}$ & $\begin{array}{l}\text { Rivera (1996) } \\
\text { Shirley, Xu and Zuluaga (2002) }\end{array}$ \\
\hline
\end{tabular}




\begin{tabular}{|c|c|c|c|c|c|c|c|c|}
\hline \multirow[b]{2}{*}{$\begin{array}{l}\text { Country } \\
\text { (City) }\end{array}$} & \multirow[b]{2}{*}{ Year } & \multirow[b]{2}{*}{$\begin{array}{l}\text { Type of } \\
\text { Contract }\end{array}$} & \multicolumn{5}{|c|}{ Effect of Reform Involving Private Sector Participation } & \multirow[t]{2}{*}{ Case Studies } \\
\hline & & & Prices & $\begin{array}{l}\text { Coverage } \\
\text { (000s of } \\
\text { Connections) }\end{array}$ & $\begin{array}{l}\text { Production } \\
\left(\text { Million } \mathrm{m}^{3} / \mathrm{yr}\right)\end{array}$ & $\begin{array}{l}\text { Unaccounted } \\
\text { for Water } \\
\text { (\% of } \\
\text { Production) }\end{array}$ & $\begin{array}{l}\text { Productivity } \\
\text { (Workers per } \\
1000 \\
\text { connections) }\end{array}$ & \\
\hline $\begin{array}{l}\text { Colombia } \\
\text { (Barranquilla) }\end{array}$ & 1991 & $\begin{array}{l}\text { Lease } \\
(20 \text { Years })\end{array}$ & --- & $\begin{array}{l}\text { INCREASED } \\
\text { Water: } \\
\text { 1991: } 60 \% \\
\text { 1993: } 67 \% \\
\text { 1995:83.3\% } \\
\text { Sewerage: } \\
\text { 1991: } 55 \% \\
\text { 1993: } 62 \% \\
\text { 1995: } 68.6 \%\end{array}$ & --- & $\begin{array}{l}\text { DECREASED } \\
\text { 1991: } 70 \% \\
\text { 1993: } 67 \%\end{array}$ & $\begin{array}{l}\text { INCREASED } \\
\text { 1991: } 7.6 \\
\text { 1993: } 4.3 \\
\text { 1995: } 3.3\end{array}$ & Avendaño and Basañes (1999) \\
\hline $\begin{array}{l}\text { Colombia } \\
\text { (Cartagena) }\end{array}$ & 1995 & $\begin{array}{l}\text { Lease } \\
\text { (26 Years) }\end{array}$ & $\begin{array}{l}\text { SIMILAR } \\
\text { According to Rivera } \\
\text { (1996), the private operator } \\
\text { committed to not changing } \\
\text { the tariff for } 2 \text { years after } \\
\text { the introduction of PSP }\end{array}$ & $\begin{array}{l}\text { INCREASED } \\
\text { 1989: } 68.2 \\
\text { 1990: } 71.8 \\
\text { 1991: } 74.7 \\
\text { 1992: } 78.2 \\
\text { 1994: } 84.1 \\
\text { 1995: } 65.0 \\
\text { 1999: } 95.0 \\
\text { 2002: } 121.7\end{array}$ & --- & $\begin{array}{l}\text { DECREASED } \\
\text { 1992: } 52.0 \% \\
\text { 1994: } 60.0 \% \\
\text { 1995: } 60.0 \% \\
\text { 1997: } 45.0 \% \\
\text { 1999: } 40.0 \% \\
\text { 2002: } 41.0 \%\end{array}$ & $\begin{array}{l}\text { IMPROVED } \\
\text { 1989: } 12 \\
\text { 1990: } 12 \\
\text { 1991: } 10 \\
\text { 1992: } 9 \\
\text { 1994: } 15 \\
\text { 1995: } 7.6 \\
\text { 1997: } 4 \\
\text { 1999: } 2.8 \\
\text { 2002: } 2.3\end{array}$ & $\begin{array}{l}\text { Rivera (1996) } \\
\text { Nickson (2001b) } \\
\text { Beato and Díaz (2003) } \\
\text { Avendaño and Basañes (1999) }\end{array}$ \\
\hline $\begin{array}{l}\text { Colombia } \\
\text { (Marinilla) }\end{array}$ & 1997 & $\begin{array}{l}\text { Service } \\
\text { Contract }\end{array}$ & --- & $\begin{array}{l}\text { INCREASED } \\
\text { Mar. 1997: } \\
\text { 5.880 (94\%) } \\
\text { 1999: } 6.754 \\
(98 \%) \\
\text { 2000: } 7.106 \\
(99 \%)\end{array}$ & $\begin{array}{l}\text { INCREASED } \\
\text { Mar. 1997: } 2.0 \\
\text { 1999: } 2.06 \\
\text { 2000: } 2.12\end{array}$ & $\begin{array}{l}\text { DECREASED } \\
\text { Mar. 1997: } \\
\text { 46\% } \\
\text { 1999: } 41 \% \\
\text { 2000: } 35 \%\end{array}$ & --- & $\begin{array}{l}\text { Arévalo and Schippner (2002) } \\
\text { Avendaño and Basañes (1999) }\end{array}$ \\
\hline $\begin{array}{l}\text { Colombia } \\
\text { (Montería) }\end{array}$ & 1994 & Lease & --- & $\begin{array}{l}\text { INCREASED } \\
\text { Water: } \\
\text { 1992: } 65 \% \\
\text { 1997: } 75 \% \\
\text { Sewerage: } \\
\text { 1992: } 23 \% \\
\text { 1997: } 23 \%\end{array}$ & --- & $\begin{array}{l}\text { UNCHANGE } \\
\text { D } \\
\text { 1992: } 55 \% \\
\text { 1997: } 55 \%\end{array}$ & $\begin{array}{l}\text { IMPROVED } \\
\text { 1992: } 9.8 \\
\text { 1997: } 0.3\end{array}$ & Avendaño and Basañes (1999) \\
\hline
\end{tabular}




\begin{tabular}{|c|c|c|c|c|c|c|c|c|}
\hline \multirow[b]{2}{*}{$\begin{array}{l}\text { Country } \\
\text { (City) }\end{array}$} & \multirow[b]{2}{*}{ Year } & \multirow[b]{2}{*}{$\begin{array}{l}\text { Type of } \\
\text { Contract }\end{array}$} & \multicolumn{5}{|c|}{ Effect of Reform Involving Private Sector Participation } & \multirow[t]{2}{*}{ Case Studies } \\
\hline & & & Prices & $\begin{array}{l}\text { Coverage } \\
\text { (000s of } \\
\text { Connections) }\end{array}$ & $\begin{array}{l}\text { Production } \\
\text { (Million } \mathrm{m}^{3} / \mathrm{yr} \text { ) }\end{array}$ & $\begin{array}{l}\text { Unaccounted } \\
\text { for Water } \\
\text { (\% of } \\
\text { Production) }\end{array}$ & $\begin{array}{l}\text { Productivity } \\
\text { (Workers per } \\
1000 \\
\text { connections) } \\
\end{array}$ & \\
\hline $\begin{array}{l}\text { Honduras (San } \\
\text { Pedro Sula) }\end{array}$ & 2000 & Concession & $\begin{array}{l}\text { DECREASE, THEN } \\
\text { INCREASED } \\
\text { Set to rise by } 20 \% \text { after the } \\
\text { third year of the contract }\end{array}$ & $\begin{array}{l}\text { INCREASED } \\
6,580 \text { new } \\
\text { connections } \\
\text { were added in } \\
2001 \text { and } 2,009 \\
\text { new } \\
\text { connections } \\
\text { were added in } \\
\text { the first } 11 \\
\text { months of } 2002 \\
\end{array}$ & $\begin{array}{l}\text { INCREASED } \\
\text { 2001: } 23.3 \\
\text { 2002: } 25.8\end{array}$ & UNKNOWN & $\begin{array}{l}\text { IMPROVED } \\
\text { 2000: } 5.41 \\
\text { 2002: } 4.37\end{array}$ & Díaz (2003) \\
\hline $\begin{array}{l}\text { México } \\
\text { (Cancún and } \\
\text { Isla Mujeres) }\end{array}$ & 1994 & $\begin{array}{l}\text { Concession } \\
\text { (30 years) }\end{array}$ & $\begin{array}{l}\text { According to Rivera } \\
\text { (1996), the contract } \\
\text { prohibited real tariff } \\
\text { increases for the hotel } \\
\text { sector during the first } 5 \\
\text { years, and other tariff } \\
\text { adjustments were to be } \\
\text { approved by the regulator. } \\
\text { Cross-subsidies remained } \\
\text { in place following the } \\
\text { entrance of the private } \\
\text { sector. }\end{array}$ & $\begin{array}{l}\text { As of } 1996, \\
\text { AGUAKAN } \\
\text { was contracting } \\
\text { to add } 10,000 \\
\text { new water } \\
\text { connections and } \\
79 \mathrm{~km} \text { of } \\
\text { sewerage } \\
\text { pipeline. This } \\
\text { would increase } \\
\text { water coverage } \\
\text { from } 63 \% \text { to } \\
74 \% \text { and } \\
\text { sewerage } \\
\text { coverage from } \\
35 \% \text { to } 45 \% \text { by } \\
\text { the end of } 1996 \text {. } \\
\text { The works } \\
\text { remained } \\
\text { inactive, } \\
\text { however } \\
\text { because of } \\
\text { insufficient } \\
\text { funds. }\end{array}$ & $\begin{array}{l}\text { INCREASED } \\
\text { 1993: } 44 \\
\text { 1995: } 47\end{array}$ & $\begin{array}{l}\text { UNCHANGE } \\
\text { D } \\
\text { 1993: } 51 \% \\
\text { 1995: } 51 \%\end{array}$ & $\begin{array}{l}\text { IMPROVED } \\
\text { 1993: } 12.8 \\
\text { 1995: } 11.4\end{array}$ & Rivera (1996) \\
\hline
\end{tabular}




\begin{tabular}{|c|c|c|c|c|c|c|c|c|}
\hline \multirow[b]{2}{*}{$\begin{array}{l}\text { Country } \\
\text { (City) }\end{array}$} & \multirow[b]{2}{*}{ Year } & \multirow[b]{2}{*}{$\begin{array}{l}\text { Type of } \\
\text { Contract }\end{array}$} & \multicolumn{5}{|c|}{ Effect of Reform Involving Private Sector Participation } & \multirow{2}{*}{ Case Studies } \\
\hline & & & Prices & $\begin{array}{l}\text { Coverage } \\
\text { ( } 000 \text { s of } \\
\text { Connections) }\end{array}$ & $\begin{array}{l}\text { Production } \\
\left(\text { Million } \mathrm{m}^{3} / \mathrm{yr} \text { ) }\right.\end{array}$ & $\begin{array}{l}\text { Unaccounted } \\
\text { for Water } \\
\text { (\% of } \\
\text { Production) }\end{array}$ & $\begin{array}{l}\text { Productivity } \\
\text { (Workers per } \\
1000 \\
\text { connections) }\end{array}$ & \\
\hline $\begin{array}{l}\text { Mexico } \\
\text { (Mexico City) }\end{array}$ & 1993 & $\begin{array}{l}\text { Service } \\
\text { Contracts }\end{array}$ & $\begin{array}{l}\text { MIXED } \\
\text { Reform was accompanied } \\
\text { by significant changes in } \\
\text { metering and billing, } \\
\text { resulting in increased } \\
\text { prices for low-income } \\
\text { consumers, but lower } \\
\text { average prices for middle- } \\
\text { and high-income } \\
\text { consumers }\end{array}$ & $\begin{array}{l}\text { INCREASED } \\
\text { 1992: } 1279.0 \\
\text { 1995:1338.0 } \\
\text { 1998: } 1652.0 \\
\text { Increase } \\
\text { appears to be } \\
\text { due to the } \\
\text { regularization } \\
\text { of existing } \\
\text { connections not } \\
\text { an actual } \\
\text { increase in } \\
\text { number of } \\
\text { connections }\end{array}$ & $\begin{array}{l}\text { UNCHANGED } \\
\text { 1992: } 1,098.0 \\
\text { 1995: } 1,118.0 \\
\text { 1996: } 1,100.0\end{array}$ & UNKNOWN & $\begin{array}{l}\text { IMPROVED } \\
\text { 1992: } 13.8 \\
\text { 1995: } 12.3 \\
\text { 1998: } 9.8 \\
\text { Improvement } \\
\text { appears to be } \\
\text { due to the } \\
\text { regularization } \\
\text { of existing } \\
\text { connections not } \\
\text { an actual } \\
\text { increase in } \\
\text { number of } \\
\text { connections }\end{array}$ & Haggarty, Brook and Zuluaga (2002) \\
\hline $\begin{array}{l}\text { Trinidad and } \\
\text { Tobago (All) }\end{array}$ & 1996 & $\begin{array}{l}\text { Management } \\
\text { Contract } \\
\text { (3 years) }\end{array}$ & $\begin{array}{l}\text { INCREASED } \\
\text { Prices were increased } 35 \\
\text { percent before the contract } \\
\text { was implemented }\end{array}$ & $\begin{array}{l}\text { INCREASED } \\
\text { 1995: } 200.0 \\
\text { 1999: } 230.0 \\
\text { [2002: } 249.0]\end{array}$ & & $\begin{array}{l}\text { IMPROVED } \\
\text { 1995: } 40 \% \\
\text { 1999: } 83 \% \\
\text { [2002: } 89 \%]\end{array}$ & $\begin{array}{l}\text { IMPROVED } \\
\text { 1995: } 17.0 \\
\text { 1999: } 9.0 \\
{[2002: 11.0]}\end{array}$ & $\begin{array}{l}\text { Stiggers (1999) } \\
\text { Nankani (1997) } \\
\text { World Bank (2003) }\end{array}$ \\
\hline
\end{tabular}

Data is from Case Studies listed in final column or from SPBNET.Africa, a project sponsored by the Water Utilities Partnership (WUP) designed to collect data on water utilities in Africa. 


\section{Appendix 2: Data Assembly Detail}

In Latin America, numerous governments have initiated water privatization or private sector participation in water and wastewater services. In some countries, governments have enacted changes in service provision at the national level, while others have been at the level of the state, province, municipality, or city. In those countries where private sector participation (PSP) has not been universal, the juxtaposition of privatized and non-privatized water utilities within a single country offers a unique opportunity to study the effects of PSP on service delivery (and, in particular, on rates of coverage for water and sanitation services).

In order to obtain data on access to piped water and flush toilets at the level of particular cities, states, and provinces, it was necessary to consult credible household surveys administered in those countries in which PSP occurred. In the 1990s, many Latin American nations benefited from the Programa para el Mejoramiento de las Encuestas y la Medición de las Condiciones de Vida en América Latina y el Caribe (the Program for the Betterment of Surveys and the Measurement of the Living Conditions of Latin America and the Caribbean, or MECOVI). The program is a joint initiative of the Inter-American Development Bank (IDB), the International Bank for Reconstruction and Development (IBRD), and the Economic Commission for Latin American and the Caribbean (ECLAC). Its central objective is to aid Latin American countries in generating adequate and high quality information regarding the living conditions of their peoples. Owing to MECOVI as well as the efforts of national statistical agencies throughout Latin America, many high-quality household surveys are available for numerous countries and years. These comprehensive surveys comprise information on education attained, income levels, and access to infrastructure for households throughout each country. They thus include sufficient information to study the changes in water and wastewater service access among different income and education groups over time.

Prior to selecting which surveys to employ, it was necessary to identify those countries in which water privatization or PSP has occurred in certain areas of the country while the sector has remained in public hands in other areas. This involved a rather involved literature review and the consultation of experts both in Latin America and the United States. The review of Latin America's experience with water privatization led us to establish a list of countries that would provide potentially interesting contrasts between regions with and without PSP. Within each of these countries, we attempted to identify as many cases as possible of water privatization or PSP in the water sector. At the same time, we carefully recorded the populations of those cities, states, and provinces which experienced PSP in the water sector and identified numerous control cities, states, and provinces with similar populations but without PSP.

Of those countries with non-universal private sector experience in water and sanitation service provision, many could not be included in our dataset for two main reasons: First, for several countries, high-quality household surveys for years preceding and following PSP in the water sector were simply not available. Specifically, we deemed it necessary to have survey data from a year preceding PSP and at least one survey from the period of between two and five years after PSP. This would provide an accurate picture of service coverage before PSP and service coverage once the PSP was in full effect. Where such a broad range of years was not available, existing surveys for that country were of limited usefulness. A second limiting factor was the 
nonexistence of sufficient household identification variables to identify whether a particular household was in the area affected by the PSP initiative. Where privatization or PSP occurred in a small or limited capacity, it was necessary to have sufficient variables to identify which households were in that small region. While coverage rates following state or province-wide PSP were easy to observe because nearly every survey dataset contained a variable for the province or state in which a household was located, smaller geographical areas (such as small and sometimes large cities) were often not identifiable using the location variables provided in some datasets. Consequently, in countries where privatization or PSP occurred at a level for which insufficient location identification variables existed in that country's surveys, the country had to be dropped from our dataset.

Such limitations resulted in a rather short list of countries: Argentina, Bolivia, and Brazil. Despite these limitations, however, our panel dataset contains a large number of observations because we included numerous years and numerous cities, states, and provinces from each of the countries with useable survey data.

For each country in our dataset, we selected multiple survey years based on several factors: first, the years for which adequate surveys were available, and second, the years in which noteworthy cases of privatization or PSP occurred. All attempts were made to gather survey data from the years immediately preceding PSP (ideally, from at least one survey in the period of between zero and three years before PSP) and for at least one year in the period two to five years after PSP. Once survey years were selected, the list of control cities, states, and provinces (earlier selected based on the criterion of having populations similar to those of regions with PSP in water) was finalized based on the availability of geographical location identification variables for each household. Where the number of control regions that could be identified far exceeded the number of regions that experienced PSP, only those with populations resembling those of the regions with PSP were considered. Where the number of control regions that could be identified was rather small, population similarity was given less weight in order to amplify the sample of control cities.

Once all countries, survey years, and sub-regions of countries were selected, the survey data on access to piped water and flush toilets within each geographical unit of interest (state, province, city, etc) was disaggregated by: 1) rural vs. urban regions, 2) education level (none, primary, primary or lower, secondary, or tertiary education) of male-headed, urban households, and 3) economic well-being (in income terms) of urban households.

Constructing variables for varying levels of educational attainment and income-related economic well-being involved yet another series of decisions about how to define each variable and at what level to disaggregate the data. Generally, where the institutions that generate and release the datasets created variables for rural and urban regions as well as household per capita income aggregates, these were utilized in the interest of consistency. All of the datasets that we employed contained variables differentiating rural and urban regions, as this was necessary to our ability to use a dataset and thus was one of the criteria for selecting surveys. Where per capita household income aggregates were not found along with the dataset, they were constructed by summing income from all earned and unearned sources that could be identified based on the questions of the survey. Based on the per capita household income of each household in the dataset, households were divided into income quintiles. In the case of Bolivia, 
where the sample size and consequently the number of observations in the dataset was smaller, households were also divided into income terciles as well (thus increasing the number of observations in each income quantile). The following table indicates the source of household per capita income data for each of the ten surveys employed:

\begin{tabular}{|c|c|}
\hline $\begin{array}{l}\text { Country/ Survey } \\
\text { Year }\end{array}$ & SOURCE OF AgGREgATE HOUSEHOLd INCOME DATA \\
\hline Argentina/ 1995 & $\begin{array}{l}\text { Household Income per capita variable accompanied the dataset } \\
\text { (created by the Instituto Nacional de Estadística y Censos) }\end{array}$ \\
\hline Argentina/ 1999 & $\begin{array}{l}\text { Household Income per capita variable accompanied the dataset } \\
\text { (created by the Instituto Nacional de Estadística y Censos) }\end{array}$ \\
\hline Argentina/ 2000 & $\begin{array}{l}\text { Household Income per capita variable accompanied the dataset } \\
\text { (created by the Instituto Nacional de Estadística y Censos) }\end{array}$ \\
\hline Argentina/ 2001 & $\begin{array}{l}\text { Household Income per capita variable accompanied the dataset } \\
\text { (created by the Instituto Nacional de Estadística y Censos) }\end{array}$ \\
\hline Argentina/ 2002 & $\begin{array}{l}\text { Household Income per capita variable accompanied the dataset } \\
\text { (created by the Instituto Nacional de Estadística y Censos) }\end{array}$ \\
\hline Bolivia/ 1995 & $\begin{array}{l}\text { Each respondent recorded three types of earned and unearned } \\
\text { income: income from the primary occupation, if employed } \\
\text { during the last web, income from a secondary occupation, if } \\
\text { employed by a second job during the last web, and total } \\
\text { income from other sources. These three types of incomes were } \\
\text { summed across individual and then across households, and the } \\
\text { total household income was divided by the number of } \\
\text { household members in order to get a measure of total per } \\
\text { capita household income. }\end{array}$ \\
\hline Bolivia/ 1999 & $\begin{array}{l}\text { Household Income per capita variable accompanied the dataset } \\
\text { (created by the Instituto Nacional de Estadistica de Bolivia) }\end{array}$ \\
\hline Bolivia/ 2001 & $\begin{array}{l}\text { Household Income per capita variable accompanied the dataset } \\
\text { (created by the Instituto Nacional de Estadistica de Bolivia) }\end{array}$ \\
\hline Brazil/ 1995 & $\begin{array}{l}\text { Total Household Income and total number of household } \\
\text { members variables accompanied the dataset (created by the } \\
\text { Instituto Brasileiro de Geografia e Estatística) }\end{array}$ \\
\hline Brazil/ 2001 & Total Household Income and total number of household \\
\hline
\end{tabular}




\begin{tabular}{|l|l|}
\hline & $\begin{array}{l}\text { members variables accompanied the dataset (created by the } \\
\text { Instituto Brasileiro de Geografia e Estatística) }\end{array}$ \\
\hline
\end{tabular}

In dividing individuals into groups of different educational attainment, it was desirable to generate an interesting contrast between individuals while maintaining a sizeable number of observations in each group. In general, individuals were classified as having primary education if they had any type of formal education (even as low as literacy courses, adult education, or preschool) that was below secondary education. Those completing any number of years of secondary education (up to and including a diploma from a secondary institution) were classified as having secondary education. Any type of post-secondary education (university coursework, post-graduate coursework, etc) was classified as tertiary education. Finally, individuals lacking formal education of any kind were identified as having no education.

Owing to the diversity of survey questions (particularly between countries) regarding an individual's educational attainment, these definitions of education produced slightly divergent groups of individuals in each country. One of the main problems encountered because of this occurred in the case of Bolivia. There, the myriad of questions regarding specific educational attainment (questions about numerous types of post-primary education were listed on the survey instrument) resulted in a very small sample size for the no education group. Our solution to this problem was to create a new education group for each of the Bolivia surveys, comprised of individuals with primary education or anything lower (including those without education). 


\section{REFERENCES AND FURTHER READING}

Abdala, Manuel Angel. "Welfare Effects of Buenos Aires' Water and Sewerage Services Privatization." Washington DC: World Bank, 1997.

Alcázar, Lorena, Manuel Abdala, and Mary M Shirley. "The Buenos Aires Water Concession." In Thirsting for Efficiency: The Economics and Politics of Urban Water System Reform, edited by Mary M. Shirley, 65-102. Oxford UK: Pergamon Press, 2002.

Anwandter, Lars, and Teofilo Jr. Ozuna. "Can Public Sector Reforms Improve the Efficiency of Public Water Utilities?" Environment and Development Economics 7 (2002): 687-700.

Artana, Daniel, Fernando Navajas, and Santiago Urbiztondo. "Governance and Regulation: A Tale of Two Concessions in Argentina." In Spilled Water: Institutional Commitment in the Provision of Water Services, edited by Pablo T. Spiller, 197-248. Washington DC: Inter-American Development Bank, 1999.

Azam, Jean-Paul, Magueye Dia, and Tchétché N'Guessan. "Telecommunications Sector Reforms in Senegal." In Policy Research Working Paper. Washington DC: World Bank, 2002.

Bitran, Gabriel A., and Eduardo O. Valenzuela. "Water Services in Chile: Comparing Private and Public Performance." In Public Policy for the Private Sector. Washington, DC, 2003.

Bourbigot, Marie-Marguerite, and Yves Picaud. "Public-Private Partnership (Ppp) for Municipal Water Services." Paper presented at the Regional Conference on The Reform of the Water Supply and Sanitation Sector in Africa, "Enhancing Public-Private Partnership in the Context of the Africa Vision for Water (2025)", Kampala, Uganda, February 26-28 2001.

Brook Cowen, Penelope J. "The Guinea Water Lease -- Five Years on [Revised]." In Public Policy for the Private Sector. Washington DC: World Bank, 1999.

Brook, Penelope J., and Alain Locussol. "Easing Tariff Increases: Financing the Transition to Cost-Covering Water Tariffs in Guinea." In Contracting for Public Services: Output Based Aid and Its Applications, edited by Suzanne M. Smith. Washington DC: World Bank, 2001.

Clarke, George, Claude Ménard, and Ana Maria Zuluaga. "Measuring the Welfare Effects of Reform: Urban Water Supply in Guinea." World Development 30, no. 9 (2002): 1517-37.

Clarke, George R.G., Frew A. Gebreab, and Henry R. Mgombelo. "Telecommunications Reform in Malawi." In Policy Research Working Paper. Washington DC: World Bank, 2003.

Collignon, Bernard. "Urban Water Supply Innovations in Côte D'ivoire: How Cross-Subsidies Help the Poor." Nairobi, Kenya: Water and Sanitation Program -- Africa, 2002. 
Crampes, Claude, and Antonio Estache. "Regulating Water Concessions: Lessons from the Buenos Aires Concession." In Public Policy for the Private Sector. Washington DC: World Bank, 1996.

Diaz, Javier. "La Participacion Del Sector Privado En Los Servicios De Agua Y Saneamiento En San Pedro Sula, Honduras." Washington, DC: Banco Interamericano de Desarrollo, Departamento de Desarrollo Sostenible, 2003.

Esrey, Steven A. "Water, Waste and Well-Being: A Multicountry Study." American Journal of Epidemiology 43, no. 6 (1996): 608-23.

Estache, Antonio, Vivien Foster, and Quentin Wodon. Accounting for Poverty in Infrastructure Reform: Learning from Latin America's Experience. Washington DC: World Bank, 2002.

Estache, Antonio, and Eugene Kouassi. "Sector Organization, Governance, and the Inefficiency of African Water Utilities." In World Bank Policy Research Working Paper. Washington, DC, 2002.

Estache, Antonio, and Martin A. Rossi. "How Different Is the Efficiency of Public and Private Water Companies in Asia?" World Bank Economic Review 16, no. 1 (2002): 139-48.

Galal, Ahmed, and Bharat Nauriyal. "Regulating Telecommunications in Developing Countries." In Policy Research Working Paper. Washington DC: World Bank, 1995.

Galiani, Sebastian, Paul Gertler, and Ernesto Schargrodsky. "Water for Life: The Impact of Privatization of Water Services on Child Mortality." 2003.

Garn, Mike, Jonathan Isham, and Satu Kahkonen. "Should We Bet on Private or Public Water Utilities in Cambodia? Evidence on Incentives and Performance from Seven Provincial Towns." In Middlebury College of Economics Discussion Paper No. 02-19. Middlebury, 2000.

Glaeser, Edward L., and Andrei Shleifer. "The Rise of the Regulatory State." In Harvard Institute of Economic Research. Cambridge, 2001.

Guasch, J. Luis, Jean-Jacques Laffont, and Stephane Straub. "Renegotiation of Concession Contracts in Latin America." In World Bank Policy Research Working Paper. Washington, DC, 2003.

Haggarty, Luke, Penelope Brook, and Ana Maria Zuluaga. "Water Service Contracts in Mexico City, Mexico." In Thirsting for Efficiency: The Economics and Politics of Urban Water System Reform, edited by Mary M. Shirley, 139-88. Oxford UK: Pergamon Press, 2002.

Haggarty, Luke, Mary M. Shirley, and Scott Wallsten. "Telecommunications Reform in Ghana." In Policy Research Working Paper. Washington DC: World Bank, 2003. 
Hall, David, and Emanuele Lobina. "Water Privatization in Latin America, 2002." Greenwich, UK: Public Services International Research Unit, 2002.

Harris, Clive, John Hodges, Michael Schur, and Padmesh Shukla. "Infrastructure Projects: A Review of Cancelled Projects." In Public Policy for the Private Sector. Washington, DC, 2003.

Jalan, Jyotsna, and Martin Ravillion. "Does Piped Water Reduce Diarrhea in Rural India." In Policy Research Working Paper. Washington DC: World Bank, 2001.

Kerf, Michel. "Do State Holding Companies Facilitate Private Participation in the Water Sector? Evidence from Cote D'ivoire, the Gambia, Guinea and Senegal." In Policy Research Working Paper. Washington DC: World Bank, 2000.

Kessides, Ioannis. "Infrastructure Regulation: Promises, Perils, and Principles." Washington DC, 2003.

Komives, Kristin. "Designing Pro-Poor Water and Sewer Concessions: Early Lessons from Bolivia." In Policy Research Working Paper. Washington DC: World Bank, 1999.

—_. "Designing Pro-Poor Water and Sewer Concessions: Early Lessons from Bolivia." Water Policy 3, no. 1 (2001): 61-79.

Komives, Kristin, and Penelope Brook Cowen. "Expanding Water and Sanitation Services to Low-Income Households." In Public Policy for the Private Sector. Washington DC: World Bank, 1998.

Laffont, Jean-Jacques, and Tchétché N'Guessan. "Telecommunications Reform in Côte D'ivoire." In Policy Research Working Paper. Washington DC: World Bank, 2002.

Lee, Terence R., and Andrei Jouravlev. "Private Participation in the Provision of Water Services: Alternative Means for Private Participation in the Provision of Water Services." In Serie Medio Ambiente Y Desarrollo, 1997.

$\mathrm{Li}$, Wei, and L. Colin Xu. "The Impact of Privatization and Competition in the Telecommunications Sector around the World." World Bank, 2002.

London Economics. "Competition in Water." London UK: London Economics, 1998.

Ménard, Claude, and George R.G. Clarke. "Reforming Water Supply in Abidjan, Côte D'ivoire: A Mild Reform in a Turbulent Environment." In Thirsting for Efficiency: The Economics and Politics of Urban Water System Reform, edited by Mary M Shirley, 233-72. Oxford, UK: Pergamon Press, 2002a. 
- "A Transitory Regime: Water Supply in Conakry, Guinea." In Thirsting for Efficiency: The Economics and Politics of Urban Water System Reform, edited by Mary M. Shirley, 273-316. Oxford, UK: Pergamon Press, 2002b.

National Economic Research Associates. "Governance and Regulatory Regimes for Private Sector Infrastructure Development." Manila: Asian Development Bank, 1997.

Nickson, Andrew. "The Cordoba Water Concession in Argentina." In Working Paper. London, UK: GHK International, 2001a.

—_. "Establishing and Implementing a Joint Venture: Water and Sanitation Services in Cartagena, Colombia." In Working Paper. London, UK: GHK International, $2001 \mathrm{~b}$.

Nickson, Andrew, and Claudia Vargas. "The Limitations of Water Regulation: The Failure of the Cochabamba Concession in Bolivia." Bulletin of Latin American Research 21, no. 1 (2002): 99-120.

Noll, Roger G. "The Economics of Urban Water Systems." In Thirsting for Efficiency: The Economics and Politics of Urban Water System Reform, edited by Mary M. Shirley, 4364. Oxford UK: Pergamon, 2002.

OECD. "Global Trends in Urban Water Supply and Waste Water Financing and Management: Changing Roles for the Public and Private Sectors." Paris: Centre for Cooperation with Non-Members Environment Directorate, 2000.

Palmer Development Group. "Ppp and the Poor in Water and Sanitation. Interim Findings. Case Study: Queenstown, South Africa." Loughborough, UK: Water, Engineering and Development Centre, Loughborough University, 2000.

Petrazzini, Ben A. "Competition in Telecoms -- Implications for Universal Service and Employment." In Public Policy for the Private Sector. Washington DC: World Bank, 1996.

Rais, Jorge Carlos, Maria Esther Esquivel, and Sergio Sour. "La Concesión De Los Servicios De Agua Potable Y Alcantarillado Sanitario En Tucumán Republica Argentina." Washington DC: Public Private Infrastructure Advisory Facility, 2002.

Rivera, Daniel. Private Sector Participation in the Water Supply and Wastewater Sector: Lessons from Six Developing Country Case Studies. Washington DC: World Bank, 1996.

Ros, Agustin J. "Does Ownership or Competition Matter? The Effects of Telecommunications Reform on Network Expansion and Efficiency." Journal of Regulatory Economics 15, no. 1 (1999): 65-92. 
Salatiel, Gustavo. "La Participacion Del Sector Privado En Los Servicios De Agua Y Saneamiento En La Provincia De Salta En Argentina." In Banco Interamericano de Desarrollo, Departamento de Desarrollo Sostenible. Washington, DC, 2003.

Shirley, Mary M, ed. Thirsting for Efficiency: The Economics and Politics of Urban Water System Reform. Oxford, UK: Pergamon Press, 2002.

Shirley, Mary M., F.F. Tusubira, Frew Gebreab, and Luke Haggarty. "Telecommunications Reform in Uganda." In Policy Research Working Paper. Washington DC: World Bank, 2002.

Silva, Gisele, Nicola Tynan, and Yesim Yilmaz. "Private Participation in the Water and Sewerage Sector -- Recent Trends." In Public Policy for the Private Sector. Washington DC: World Bank, 1998.

Stiggers, David. "Private Participation in Water and Wastewater Services in Trinidad and Tobago." In Can Privatization Deliver? Infrastructure for Latin America, edited by Robert D. Willig, 245-54. Baltimore, MD: John Hopkins University Press, 1999.

Suez-Lyonnaise des Eaux. "Bridging the Water Divide." Paris, France: Suez-Lyonnaise des Eaux, 2001.

Trémolet, Sophie. "Multi-Utilities and Access." In Public Policy for the Private Sector. Washington DC: World Bank, 2002.

Trémolet, Sophie, Sara Browning, and Charlotte Howard. "Emerging Lessons in Private Provision of Infrastructure Services in Rural Areas: Water Services in Côte D'ivoire and Senegal." London, UK: The World Bank/PPIAF, 2002.

Trémolet, Sophie, and Joanna Neale. "Emerging Lessons in Private Provision of Infrastructure Services in Rural Areas: Water and Electricity Services in Gabon." London UK: World Bank/PPIAF, 2002.

Tynan, Nicola. "Private Participation in Infrastructure and the Poor: Water and Sanitation." In Infrastructure for Development: Private Solutions and the Poor. London, 2000.

Wallsten, Scott. "An Econometric Analysis of Telecom Competition, Privatization, and Regulation in Africa and Latin America." Journal of Industrial Economics 49, no. 1 (2001): 1-20.

Winston, Clifford. "Economic Deregulation: Days of Reckoning for Microeconomists." Journal of Economic Literature 31, no. 3 (1993): 1263-89.

World Bank. "Project Appraisal Document: Long Term Water Supply Project." Washington DC: World Bank, 2001. 
- World Development Report 1994: Infrastructure for Development. Oxford, UK: Oxford University Press, 1994.

Zérah, Marie-Hélène. "The Cancellation of the Pune Water Supply and Sewerage Project." New Delhi, India: Water and Sanitation Program - South Asia, 2000. 